







\section{Order SIPHONAPTERA.}

Contains the fleas which are considered as flies, modified to suit a parasitic mode of life. They are usually browu in color, transversely flattened, the edges of the segments set with stiff spines directed backward, and the hind legs enormously developed for leaping. They drop their eggs in the sleeping quarters of their host, and from these come slender, white, worm-like larræ. These feed on refuse animal or vegetable debris and the pupæ hide in crevices, or in houses between the boards of floors.

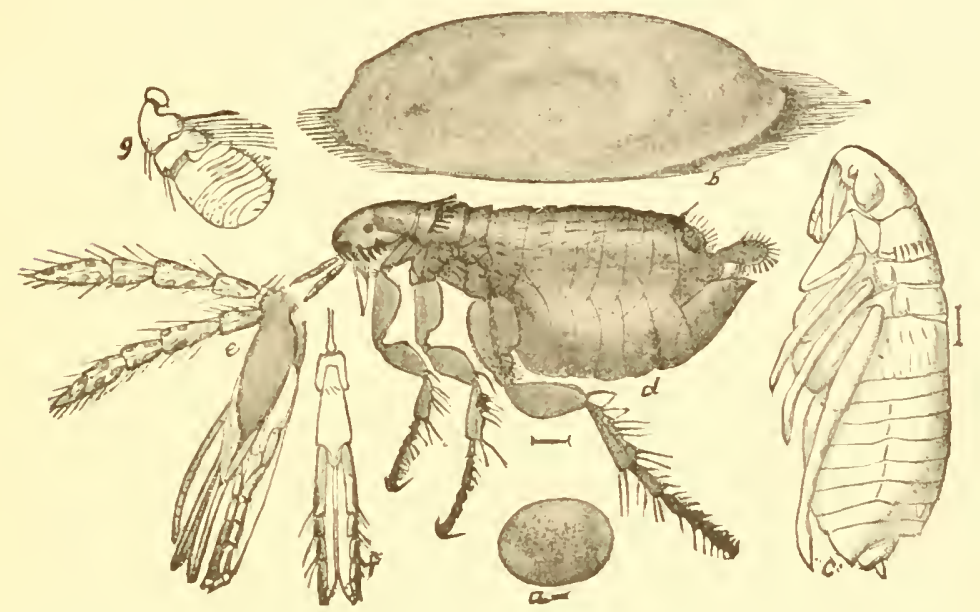

Fig. 292.--The dog tlea, Ctenocephalus canis: $a$, egg; $b$, larva in cocoon; $c$, pupa; $d$, adult; $e, i . g$, details of mouth and antennal structure; all enlarged.

Sometimes a house becomes overrun with fleas, and in such cases the sleeping place of the dog or cat must first be thoroughly cleaned, so as to destroy the source of the trouble. All the adult fleas will get upon the dog or cat at the first opportunity, and these pets, therefore, can be used as traps, then washed with carbolic soap at short intervals until all the fleas have been captured and destroyed. A free use of gasoline in the crevices of the floor will kill all larvæ and pupæ that may be there, and will at once check breeding.

No systematic collections have been made in New Jersey. I have taken fleas from moles, rabbits, muskrats, and have seen them in quantities in nests of field mice. They also occur on rats and on almost every other hairy animal in the State, but no effort has yet been made to determine the species.

Those listed here occur practically everywhere. The names are from the list published by C. F. Baker in 1904, and it is remarkable that at that

$$
(701)
$$


702 REPORT OF NEII JERSEY STATE MUSEUM.

time the author had practically no material from the middle Atlantic States.

\section{Family PULICID正. \\ PULEX Linn.}

P. irritans Linn. The human flea. Not a native of New Jersey, but is almost cosmopolitan, and specimens are occasionally found, brought from more southern States.

\section{CTENOCEPHALUS KOI.}

C. canis Curt. (Pulex serraticeps) The common cat and dog flea. CERATOPHYLLUS Curtis.

C. wickhami Baker. (Pulex howardi) One of the squirrel fleas. CTENOPHTHALMUS Kol.

C. pseudarytes Baker. A parasite on field mice. 




\section{Order DIPTERA.}

This order contains the flies, always recognizable by having two wings only, the secondaries Deing reduced to little linobs or halteres. The head is separated from the thorax by a distinct, very narrow neck, and the antennæe are either quite long or very short. often aristate. The mouth parts are forned for scraping or sucking, or both, and never for chewing, in the adult stage. The larve vary greatly, but are usually either very slender and elongate, or maggot-like in form. The metamorphosis is complete, and the change from larva to adult is more radical than in any other order.

Since the publication of the previous list our knowledge of the "Diptera" has increased rastly, and collectors are more numerous than ever before. Mr. Charles W. Johnson, now Curator of the Boston Society of Natural lfistory, has again prepared the list as a whole, and has added perhaps the greatest number of species to it. But in the "Cecidomyiidre" Mr. William Beutenmuller has done this work, and while the list in that lamily is still far from complete, it is a much better picture of our fauna than was the previous one. In the "Culicida" the list is probably almost complete. In no other family have collections been so thorough and systematic, and it is belicred that few species will be added in future. Mr. John A. Grossbeck, one of the assistants in the mosquito investigation. has written this part of the list. In the "Tabanidæ" Mr. V. A. E. Daecke has supplied the mss., and here again his persistent and careful work. supplemented by that of Mr. Henry S. Harbeck, has left little to be done. In addition to these gentlemen. Messis. G. M. Greene and Chas. T. Greene, of Philadelphia, have added many records, and nearly all the contributors to the previous edition have helped along the work on this.

Mr. Johnson estimated that the 1.200 species listed in the last edition were about two-thirds of the actual number to be found in the State. As before, all records not otherwise specifically credited belong to Mr. Johnson.

\section{Family TIPULID五.}

These are the "Crane-flies," which resemble exaggerated mosquitoes in appearance, and derive the common name from their long, ungainly, slender legs. The head is often prolonged into a sort of blunt snout at the end of which are the prominent palpi, which are sometimes as long as the antennæ.

The species are most common in low meadows or at the edges of woodland, and their flight is as uncertain and awkward as their appearance. It is difficult to preserve these insects, because the legs break off at the least provocation, even when they are alive. 


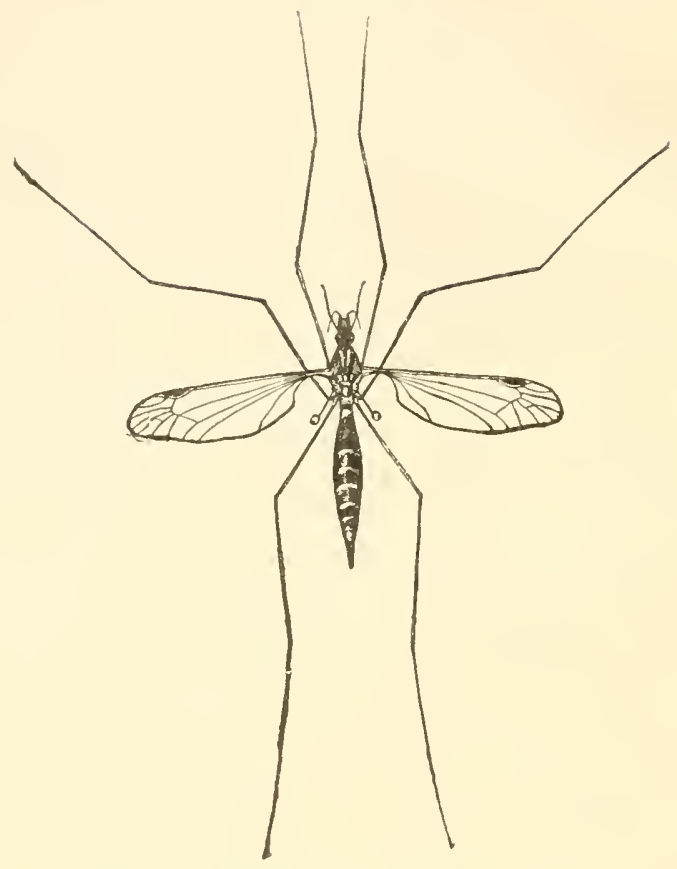

Fig. 293.-A crane fly, Pachyrhina species.

The larvæ of most of these flies are slender, cylindrical, worm-like, and very tough, whence they are known as "wire worms" in England, where they are often injurious on sod land and to root crops. This type lives in the soil, and may feed on either living or dead vegetation. A few feed on ieares and somewhat resemble caterpillar's, but in no case are they injurious in New Jersey, so far as I have had any knowledge of them.

\section{GERANOMYIA Haliday.}

G. rostrata Say. Lenola, Clementon V, 30 (Jn); Riverton V, 19, VII, 3, IX, 11 (div), National Park TI, 3 (Dke).

G. canadensis Westw. "New Jersey" (A E S), Cape May IX, 21 (Vk).

G. diversa O. S. "New Jersey" (A E S).

G. distincta Doane. Manumuskin VI, 23 (Dke).

\section{RHIPIDIA Meig.}

R. maculata Meig. "New Jersey" (A E S).

R. domestica O. S. Palisades (O S); Clementon $\mathrm{T}$, 16, bred from larva obtained in fermented sa! of "Nyssa sylvatica," Riverton VI, 16. 


$$
\text { . }
$$



R. fidelis O. S. Chester V'III, 9 (Coll).

R. bryanti Johns. Dover VI, 25.

TROCHOBOLA O. S.

T. argus Say. Palisades $V(\mathrm{Lr})$.

\section{DICRANOMYIA Steph.}

D. rara O. S. Dover VI, 23.

D. liberta O. S. Jamesburg (Sm); Clementon VI, 3.

D. stulta O. S. "New Jersey" (A E S).

D. morioides O. S. "New Jersey" (A E S).

D. pubipennis O. S. "New Jersey" (Bt).

D. simulans Wlk. (deruncta O. S.) Caldwell VI, $8(\mathrm{Cr})$.

D. hæretica O. S. Caldwell (Cr); Jamesburg (Sm).

D. badia Walk. Forest Hill X (Wilt).

D. immodesta O. S. Forest Hill IX (WJt); Lucaston IX, 28, X, 15 (Dke).

D. gladiator O. S. Avon IX, 27 ( HK).

\section{LIMNOBIA Meig.}

L. immatura O. S. Boonton V'II, 18 (GG); CaIdwell (Cr).

L. cinctipes Say. Caldwell (Cr).

L. triocellata O. S. Dunnfield, Del. Water Gap VII, Asbury Park VIII, 16. Westrille VI, 6 (Jn); Lucaston IX, 28 (Dke).

L. fallax Johns. (solitaria Johns, not O. S.) Dunnfield, Del. Water Gap VII, 11.

L. tristigma O. S. Dunnfield, Del. Water Gap VII, 11.

L. sociabilis O. S. Caldwell ( $\mathrm{Cr}$ ).

L. indigena O. S. Merchantrille VI, $t$. (Dke).

\section{TOXORRHINA LOEW.}

T. magna O. S. Type "New Jersey" VII (A E S); Wildwood VIII, 12.

\section{RHAMPHIDIA Meig.}

R. flavipes Macq. Riverton VII, 31, VIII, 25, Clementon VI, 3 (Jn); National Park $\mathrm{V}, 20$ (Dke).

\section{ELEPHANTOMYIA O. $S$.}

E. westwoodi O. S. Delaware Water Gap VII, 12.

ATARBA O. S.

A. picticornis O. S. Riverton VI, 18 . 


\section{DICRANOPTYCHA O. S.}

D. germana O. S. "New Jersey" (A E S).

D. sobrina O. S. New Hope VII, 10 (Hk).

\section{TEUCHOLABIS O. S.}

T. complexa O. S. Avalon; larva in considerable number under bark VI, 8; commenced pupating in 4 or 5 days; imagoes VII, 22-27.

\section{CLADURA O. S.}

C. flavoferruginea O. S. Forest Hill IX (Wdt).

ANTOCHA O. S.

A. saxicola O. S. (opalizans O. S.) Dunnfield, Del. Water Gap VII, $10 .$.

\section{RHYPHOLOPHUS Kol.}

R. innocens O. S. Westville IV, 9 (Jn); Riverton IV, 10 (Dke).

R. nubilus O. S. Newark IV (Wdt).

\section{ERIOPTERA Meig.}

E. chlorophyl!a O. S. Common; Riverton VI, 19, VII, 3, Westville VII, 2.

E. straminea O. S. Riverton VI, 18.

E. venusta O. S. Riverton VI, 15, Merchantville V, 26 (Dke); Woodbury VI, 7.

E. septemtrionalis O. S. Riverton VII, 3.

E. armata O. S. "New Jersey" (A E S, Bt) ; Orange Mts. VI.

E. chrysocoma O. S. Riverton VI, 18, Westville VII, 2.

E. caloptera Say. Boonton IX, 18 (GG); Riverton VII, 3, Avalon VII, 22.

E. dulcis O. S. Del. Water Gap VII, 13, Riverton VI, 16 (Jn).

E. parva O. S. Del. Water Gap VII, 13 (Jn); Orange VI (O S).

E. vespertina O. S. "New Jersey" (A E S).

\section{MOLOPHILUS Curtis.}

M. forcipula O. S. South Orange (O S).

M. hirtipennis O. S. Orange (O S).

M. ursinus O. S. Ashland V, 13 (Hk); Clementon V, 14 (Jn).

M. pubipennis O. S. Chester VIII, 1 (Coll); Shark River VII, 12.

\section{GONIOMYIA O. S.}

G. manca O. S. South Orange VI, 30, 1868 (O S).

G. blanda O. S. Long Branch VI, 12.

G. sulphurella O. S. Riverton V, 28, Asbury Park VIII, 16.

G. cognatella O. S. Clementon V, 12. 


HELOBIA St. Farg. (SYMPLECTA Meig.)

H. hybrida Meig. (punctipennis Meig.) Riverton IX, 25, Shiloh IX, 1 (Jn); Aron IX, 27, Pemberton V, $20(\mathrm{Hk})$.

TRIMICRA O. S.

T. anomala O. S. Anglesea V, 30, VII, 9 (Sm).

GNOPHOMYIA O. S.

G. tristissima O. S. DeI. Water Gap VII, S, Westville VI, 6 (Jn); New Hope VII, $10(\mathrm{Hk})$.

ULOMORPHA O. S.

U. pilosella O. S. Shark River VII, 12 .

\section{TRICHOCERA Mieig.}

T. regelationis Linn. CaldweII V, $5(\mathrm{Cr})$; Camden II, 21, Westville IV, 9.

T. bimacula Walk. Riverton IX, 3.

T. brumalis Fitch. Riverton IX, 3 .

\section{EPIPHRAGMA O. S.}

E. fascipennis Say. New Hope VIII, 10 (Hk); Newark VI, 16, Riverton V. 29, Clementon VI, :, Woodbury VI, 7.

\section{LIMNOPHILA MaCq.}

L. fuscovaria O. S. Jamesburg VII, 4, Westville V'I, 6, Clementon VIII, 9.

L. luteipennis O. S. Wenonah VI, 29 (Hk): Woodbury V1. 7, Westville VII, 2, Lenola V, 30.

L. tenuipes O. S. Riverton VII, 24.

L. macrocera Say. Westrille VI, 6, Merchantville V, 26. VI, 4 (Dlie).

L. adusta O. S. "New Jersey" (A E S); Testville T, 18.

L. recondita O. S. Long Branch VI, 12, Riverton VII, 24.

L. rufibasis O. S. Dover VI, 11 (Jn); Culver's Lake V., 29 (Coll); Orange Mits. Y ( $\left.T^{\top} d t\right)$.

L. imbecilla O. S. "New Jersey" (A E S).

L. toxoneura O. S. "New Jersey" (A E S).

L. Ienta O. S. Orange MIts.

L. contempta O. S. Westville VII, 21 (Jn); Lakehurst VIII, 23 (Coll).

L. quadrata O. S. Culver's Lake V, 29 (Coll).

L. irrorata Johns. Riverton VIII, 5.

\section{ERIOCERA Macq.}

E. fuliginosa O. S. Orange Mts. VII, 4.

E. brachycera O. S. Dunnfield, Del. Water Gap VII, 14 (Jn); Orange Mts. VI (Wdt). 


\section{O8 REPORT OF NEW JERSEY STATE MUSEUM.}

E. wilsonii O. S. "New Jersey" (A E S).

E. longicornis Walk. Passaic VI, \& (Coll); Trenton V, 30 (Hk).

\section{PENTHOPTERA Schiner.}

P. albitarsis O. S. Del. Water Gap VII, 11, 12, Shark River VII, 12, Clementon VIII, 7 (Jn); Trenton VII, 12 ( $\mathrm{Hk})$.

\section{AESHNASOMA Johnson.}

A. rivertonensis Johns. Riverton VII, 20, 1902.

\section{TRICYPHONA Zett. (AMALOPIS Haliday.)}

T. inconstans O. S. Del. Water Gap VII, 11, Woodbury V, 14, Westville VI, 6, Shiloh IX, 1 (Jn) ; Riverton V, 19, Wenonah VI, 23 (Hk); Lucaston IX, 22 (Dke).

T. vernalis O. S. Lucaston IV, 14, IX, 28 (Dke); Clementon V, 5 (Hk).

\section{PEDICIA Latr.}

P. albivitta Wlk. Dunnfield, Del. Water Gap VII, 11, 15 (Jn); Caldwell (Cr) ; Riverton IX, 10 (Vk).

\section{LIOGMA O. S.}

L. nodicornis O. S. "New Jersey" (A E S).

\section{BITTACOMORPHA Westwood.}

B. clavipes Fab. Caldwєll (Cr); Westville V, 19, Atco VI, 18 (Jn); Riverton IV, 24, X, 9 (div); Jamesburg V, VI, along ditches, Lahaway $\mathrm{V}, 28(\mathrm{Sm})$.

B. jonesi Johns. Clementon V, 5 (Hk).

PTYCHOPTERA Meig.

P. rufocincta O. S. Newark VI, 16, Riverton V, 30, Westville VII, 12 (Jn); Clementon VI, 7 (Li); Wenonah VI, 23 (Hk).

\section{BRACHYPTEMNA O. S.}

B. dispellens Walk. Shark River VH, 12, 1897.

\section{OROPEZA Needham. (DOLICHOPEZA Curt.)}

O. albipes Johns. Del. Water Gap VII, 21, Dover VI, 17, Riverton VIII, 3.

O. subalbipes Johns. Long Branch VI, 12, Westville VI, 6, Clementon VI, 3.

O. obscura Johns. Riverton VIII, 11.

O. sayi Johns. (T. annulata Say not Linn.) Westville VI, 6. 



\section{XIPHURA Brullé.}

X. frontalis O. S. Palisades $Y(L v)$.

X. fumipennis O. S. (Ctenophora) Palisades VI, 6 (Lv).

\section{CTENOPHORA Meig.}

C. nubecula O. S. Caldwell V, $29(\mathrm{Cr})$.

\section{PACHYRHINA Macq.}

P. ferruginea Fab. Common; Del. Water Gap VIl, 11-15, New Brunswick, Riverton, Shiloh IX, 1 (Jn); Trenton V, 21 ( $\mathrm{Hk}$ ).

P. incurva Loew. Newark VI, 14, New Brunswick VII, 1, Westrille VI, 6.

P. collaris Say. Westrille 1Y, 9 (Jn); Lıcaston IV, 10-14 (Dke).

P. virescens Loew. Del. Water Gap V'II, 11, 15, Dover VI, 23, Newark II, 14, Riverton V'I, 19, Westrille V'II, 21.

P. tenuis Loew. Del. Water Gap Y'II, 10, Newark VI, 14, Westville VI, 6 $(\mathrm{Jn})$; Iona $\mathrm{V}, 2$ t (Dke).

P. eucera Loew. Passaic VI, S (C'oll); Ft. Lee VI, 23 (Dke); Long Branch VI, 12, DaCosia VI, 4.

P. unifasciata l.oew. Dunnfield, Del. Water Gap VII. 14 (Jn); Trenton VII. 7 ( $\mathrm{Hl})$.

P. sodalis Loew. Orange MIts. VI, 22, Westville VI, 6 (Jn).

P. macrocera Say. Newark YI, 14, Westrille YI, 27.

P. xanthostigma Loew. Riverton VII, 3.

P. punctum Loew. Del. Water Gap V'Il, 1, Riverton VII, 24.

P. polymera Loew. Riverton VI, 14 .

\section{STYGEROPIS LoeW.}

S. fuscipennis Loew. "Salt mealow" Newark VI (Wdt).

\section{LONGURIO LOeW.}

L. testaceus Loew. Dunnfield, Del. Water Gap VII, 12, 15.

\section{TIPULA Linn.}

T. abdominalis Say. Boonton IX, 17 (GG); Morris Plains (Jn); Caldwell $(\mathrm{Cr})$.

T. caloptera Loew. Del. Water Gap VII, 15, Dover VI, 17 (Jn): Ocean County $(\mathrm{Sm})$; Iona $\mathrm{V}, 24$ (Dke).

T. trivittata Say. Dunnfield, Del. Water Gap VII, 11, 15, Newark VI, 13 (Jn); National Park VI, 13 (Dke).

T. bella Loew. Clementon V, 10, Westville VIII, 21, Riverton IX, 11 (Jn); Wenonah VI, 23 (Hk); Anglesea IX, 12 (Dke).

T. longiventris Loew. Dover VI, 17, Newark VI, 12 (Jn); Clementon V, $30(\mathrm{Hk})$; Manumuskin $\mathrm{V}, 10$ (Dke). 


\section{IO REPOR'T OF NEW JERSEY STATE MUSEUM.}

T. fuliginosa Say. Dover VI, 17, Newark VI, 13.

T. hebes Loew. Caldwell (Cr); Ft. Lee VIII, 30 (Dke); Westville IX, 13.

T. fasciata Loew. Del. Water Gap VII, 11, Palisades, Jamesburg VII, 4, Clementon V, 30, VIII, 11 (Jn); Passaic VI, 8 (Coll).

T. tricolor Fab. Del. Water Gap VII, 15, Jamesburg VII, 21, Clementon VIII, 11, Westvile VIII (Jn); Riverton IV, 21 (Hk).

T. costalis Say. Caldwell (Cr), Princeton VII, 21, Riverton IX, 9 (Jn); Lucaston IX, 12 (Dke).

T. cunctans Say. Riverton IX, 25, X, 9.

T. speciosa Loew. Dover VII, 17, Newark VI, 13.

T. submaculata Loew. Del. Water Gap VII, 15 (Jn); Caldwell (Cr); Laurel Springs VI, 10 (Dke).

T. valida Loew. Del. Water Gap VII, 15, Dover VI, 23 (Jn); New Brunswick VI, $9(\mathrm{Sm})$.

T. dejecta Walk. Orange MIts. (Jn); Riverton IV, 22, Lucaston IV, 10 (Dke); Clementon IV, 15, V, 5 (div).

T. tephrocephala Loew. Dunnfield, Del. Water Gap VII, 8 (Jn); Ft. Lee VII, 4, Stone Harbor VII, 29 (Dke).

T. cincta Loew. Riverton IV, 17 (Jn); National Park V, 6, Manumuskin IV, 27 (Dke).

T. strepens Loew. Newark VI, 31, Riverton V, 30.

T. flavicans Fab. Manumuskin X, 21 (Dke).

T. latipennis Loew. New Brunswick VI, 9, Ocean County (Coll).

T. perlongipes Johns. Orange Mts. V, Avalon VI, 30.

T. pallida Loew. Dover VI, 17.

T. angustipennis Loew. Culver's Lake VI, 29 (Coll).

T. jejuna Johns. Riverton VII, 20.

\section{Family DIXIDF:}

Small, slender mosquito-like species, wings bare, antennæ thick at base, other joints hair-like, joints indistinctly marked; larvæ aquatic. Our species are not of economic importance.

\section{DIXA Meigen.}

D. notata Loew. Dunnfield, Del. Water Gap VII, 11, 15.

D. terna Loew. Dunnfield, Del. Water Gap VII, 11.

\section{Family PSYCHODID瓜.}

\section{PSYCHODA Latr.}

P. alternata Say. Cape May VIII, 20 (Vk); Lucaston IX, 14 (Dke); bred from water.

P. marginalis Banks. Riverton V, 14; National Park V, 6-20 (Dke).

P. minuta Banks. Riverton IX, 14. Common on trunk of the buttonwood. 


P. cinerea Banlis. Riverton VI, 8 .

P. superba Banks. Rivelton VII, 29.

P. albitarsis Banks. Del. Water Gap VII, 8, 15.

\section{Family STENOXENID王.}

STENOXENUS Coq.

S. johnsoni Coq. Type of the family and genus was collected at Dunnfield, Del. Water Gap VII, 11, 1908; very rare, and habits in early stages unknown.

\section{Family CHIRONOMIDE.}

These flies are indifferently named "gnats," "midges," sand-flies" or "punkies," the latter two names chiefly applied to the few minute forms with piercing mouth parts. They somewhat resemble mosquitoes in appearance, but have naked wings, and the thorax is produced so as to hide the small head from above. The antennæ in the male are lengthily plumese, and in the female are also furnished with lateral hair. The insects occur at all seasons, many of them in spring, and they dance in the early evening in great swarms only a few feet above ground, usually in a damp locality. The larvæ live in water on living or dead vegetation, or on sap of trees, under fallen leaves or decaying vegetable matter.

As a rule, they are harmless, except for the annoyance caused by the biting tribes, but the larva of one species at least mines the leaves of water plants, and thus becomes injurious in a very limited and special way.

\section{CERATOPOGON Meigen.}

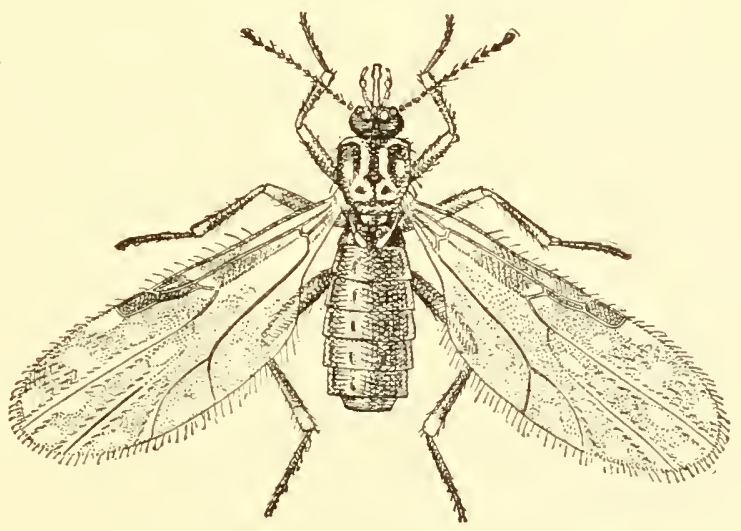

Fig. 294-Ceratopogon stellifer; much enlarged.

C. exilis Coq. Riverton $\mathrm{X}, 9$.

C. fusculus Coq. Riverton IV, 30 . 
C. specularis Coq. Riverton $\mathrm{X}, 9$.

C. transiens Walk. Riverton VIII, 21 (Jn); Manahawkin IX, 5 (Hk).

C. piceus Winn. Atlantic Highlands VII, 1 (Lv); Clementon V, 16 (Jn).

\section{CULICOIDES Latr.}

C. variipennis Coq. Westville VI, 6 .

C. cinctus Coq. Riverton X, 9 .

\section{BEZZIA Kieffer.}

B. albiventris Loew. Riverton VI, 16.

B. elegans Coq. Riverton V, 14.

B. expolita Coq. Riverton VI, 3 (Jn); Glassboro V, 19 (Hk).

B. johnsoni Coq. Riverton VI, 3.

B. media Coq. Riverton VIII, 7.

B. pulverea Coq. Riverton VII, 3.

B. setulosa Loew. Riverton VII, 3.

B. smithii Coq. (mundus Coq. not Loew.) Riverton VI, 16.

\section{JOHANNSENIELLA WIII.}

J. albaria Coq. Del. Water Gap, VII, 12, Westville VII, 12.

J. argentata Loew. Princeton VII, 21, Westville VII, 29.

J. bimaculata Loew. Riverton VI, 6, Westville VII, 21.

J. diversa Coq. Riverton VII, 7.

J. nebulosa Coq. Riverton VI, 19.

J. viridis Coq. Riverton VI, 16.

\section{PALPOMYIA Megerle.}

P. flavipes Meig. Del. Water Gap VIII, 8, Woodbury V, 14.

P. longipennis Loew. Westville VI, 27.

P. lineatus Meig. Westville VI, 6.

P. rufus Loew. Newark VI, 13, Westville VII, 27, Atco VI, 4 (Jn); Clementon $\mathrm{V}, 6$ ( $\mathrm{Hk})$.

P. tibialis Meig. Woodbury VI, 7.

P. trivialis Loew. Culver's Lake V, 29 (Sm); Princeton VII, 21, Westville VI, 27, Clementon VI, 3 (Jn); Trenton VII, 5, Brown's Mills VII, 10 ( $\mathrm{Hk})$.

\section{HETEROMYIA Say.}

H. fasciata Say. Westville VI, 15, VII, 2, Camden VI, 6. Buena Vista VI, 9 (Li), Riverton VI, 16-20.

H. festiva Loew. "New Jersey" (A E S).

H. plebeja Loew. Westville VII, 21.

H. basalis Walk. Riverton VII, 12 . 


THE INSEC'L OF NEW JERSEL. T\%

PROCLADIUS Skuse.

P. scapularis Loew. Riverton VII, 24.

P. thoracicus Loew. Riverton VI, 19, Westrille VII, 21.

TANYPUS Meigen.

T. dyari Coq. Forest Hill (Wdt); New Brunswick IV, 30 (Sm); Lucaston $\mathrm{r}, 30$ (Dke).

T. melanops Meig. Riverton V, 14, Westrille VI, 6, Clementon VI, 3.

T. pilosellus Loew. Riverton VI, 30.

T. johnsoni Coq. Riverton IV, 30, VI, 18 .

T. monilis Limn. (annulatus Say.) Great Piece Neadow $T, 7$ (Coll); Riverton $\mathrm{Y}, 14, \mathrm{IX}, 5$.

T. bifasciatus Coq. Riverton IV, 30 .

T. pallens Coq. Riverton.

T. baltimoreus Nacq. Riverton V, 14, VI, 18 .

T. turpis Zett. Boonton III, 8,12 (GG).

PSILOTANYPUS Kieffer.

P. occidentalis Coq. Riverton IX, 14.

PROTENTHES Johannsen.

P. culiciformis Linne. Riverton (Jn); Lahaway VI, 10 (Coll).

\section{CHASMATONOTUS LOEW.}

C. bimaculatus O. S. Westrille (Vki).

THALASSOMYIA Schiner.

T. platypus Coq. Dunnfield, Del. Water Gap VII, 8 .

\section{CHIRONOMUS Meigen.}

C. brunneus Walk. Dover VII, 16.

c. cristatus Fab. New Brunswick (Sm); Common, Westville VI, 6, Clementon V, 10, Riverton III, 20, Shark River VII, 12 (Jn).

C. jucundus Walk. Riverton VIII, 21.

C. lineola Wied. Common, Westrille VI, 6, VII, 4, VIII, 13.

C. modestus Say. Westville VIII, 13, Riverton V 14 .

C. pedestris Meig. Dunnfield, Del. Water Gap VII, \&, 12.

C. dispar Neig. Clementon VI, 3, VIII, 11.

C. brachialis Coq. Asbury Park VIII, 16, Westville VI, 21.

C. pedellus De Geer. Riverton IV, 30, V, 14, Clementon VI, 3.

C. fascipennis Zett. Clementon VI, 3.

C. tæniapennis Coq. Dunnfield, Del. Water Gap VII, S. 


\section{I4 REPORT OF NEW JERSEY STATE MUSEUM.}

C. albipennis Meig. Riverton VI, 7-20, Westville VI, 6.

C. tendens Fab. Clementon VI, 3, Riverton IV, 30.

C. viridicollis V. d. W. Riverton IV, 30 .

C. nitidulus Coq. Riverton $\mathrm{V}, 14$.

C. tenellus Zett. Del. Water Gap VI, 12.

C. fascipes Coq. Riverton VIII, 11.

C. festivus Say. Westville.

C. ferrugineovittatus Zett. Clementon V, 11 (GG).

c. aberrans Johans. "New Jersey."

C. nigricans Johans. Culver's Lake V, 29 (Sm); Riverton.

c. riparius Meig. "New Jersey."

C. prasinus Meig. Cave May IX, 24 (Sm).

c. brunneipennis Johans. New Jersey.

C. dorsalis Meig. Orange VI, 22 (Coll); Delair VII, 14.

C. zonopterus Mitchell. Clementon.

\section{CAMPTOCLADIUS V. d. WuIP.}

C. byssinus Schrank. Riverton IV, 30 .

C. aterrimus Meig. "New Jersey" (Johannsen).

ORTHOCLADIUS V. d. WuIp.

O. nivoriundus Fitch. Riverton IV, 15, Shark River VII, 12.

O. par Coq. Riverton VII, 3.

o. politus Coq. Riverton VIII, 17 .

CRICOTOPUS V. d. WuIp.

C. sylvestris Fab. Dreer's water garden, Riverton VI, 9, larvæ injure leaves of "Victoria regia" (Sm); Westville VI, 6 (Jn), Anglesea V, $28(\mathrm{Sm})$.

C. geminatus Say. Riverton VI, 16-18.

C. tremulus Linn. Dunnfield, Del. Water Gap VII, 8-12, Riverton V, 14.

METRIOCNEMUS V. d. WuIp.

M. par Johans. "New Jersey."

EURYCNEMUS V. d. Wulp.

E. scitulus Coq. Riverton IV, 30 , VI, 4, VIII, 3.

\section{Family CULICID无.}

These are the mosquitoes, for which New Jersey has a well-established reputation. Among the biting flies they are distinguished by their slender body, long slender legs and long slender beak or proboscis. The larvæ, 




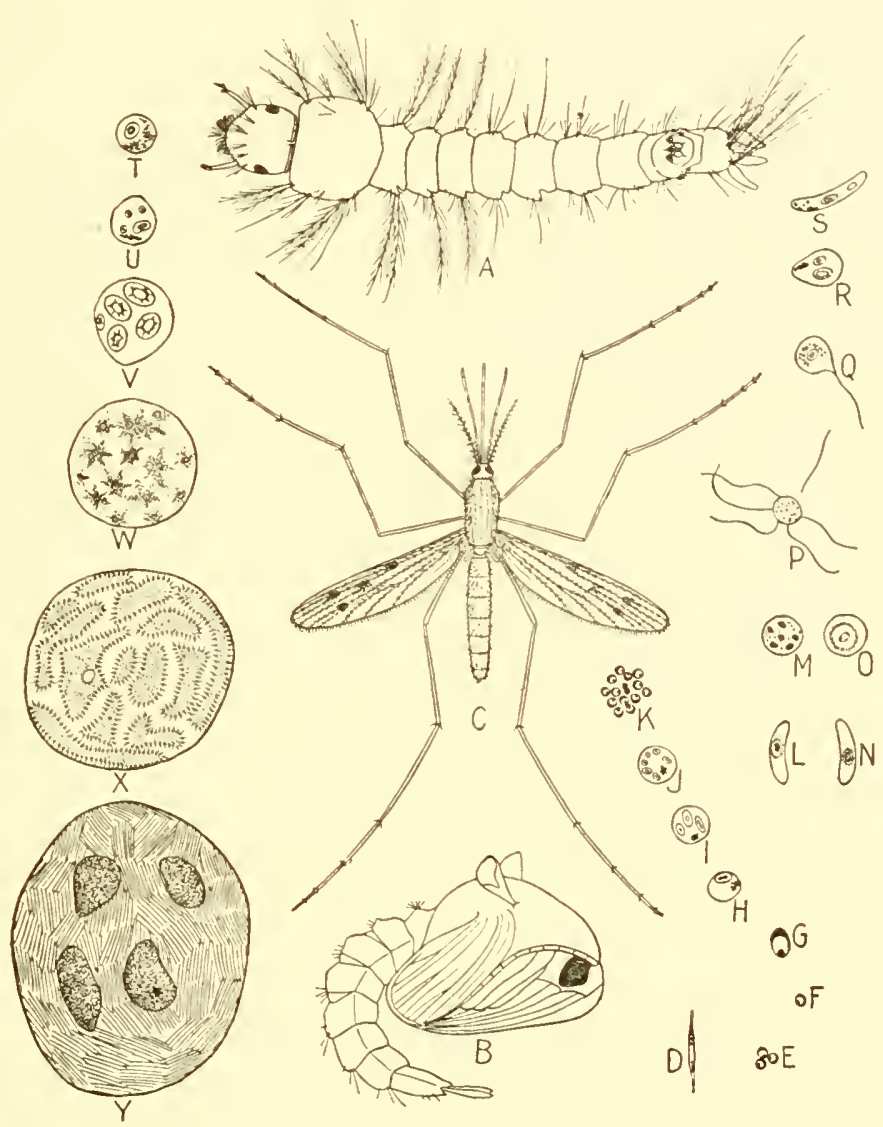

Anopheles and Malaria: $a$, larva; $b$, pupa; $c$, adult; $d$, the blast introduced into the blood by the mosquito; $e$ to $j$, stages through which the Plasmodium passes in the red blood-corpusclc; $k$, the spores which enter new blood-corpuscles; $l, m$, the microgamete; $n, o$, the macrogamete: $p$, flagellix forming; $q$, union of a flagellum with macrogamete; $r$, fusion of nuclei; $s$, the vermicule; $t$ to $y$, formation of the zygote in the mosquito stomach; the fully developed zygote, $y$, rupturing to roduce blast: i.

Fig. 295. 


\section{I6 REPORT OF NEII JERSEY STATE, MUSEUM.}

known as wrigglers, live in water, and can develop in water only; but the conditions under which the different species live vary greatly. Not all the mosquitoes bite human beings and only a few of them follow him into his habitation, so that the majority of species are indifferent to the great bulk of mankind. But some species are either almost unbearable pests, rendering large areas almost uninhabitable, or are actual carriers of disease organisms. Destructive methods for the pestiferous species are now well understood, and the day of their control is almost at hand.

\section{ANOPHELES Meig.}

The members of this genus are intermediate hosts for the organism causing malaria in man, though of the species occurring in New Jersey only one--"quadrimaculatus"- has been actually convicted of that offense. The adults may be known by their method of holding the body at a nearly right angle to the plane of the surface upon which they are at rest. The eggs are laid singly on the surface of the water and the larva float on the surface, parallel with it. They inhabit pools of ground-water, the edges of overgrown swamps or ponds, the quiet eddies of sluggish streams and sometimes even lot-pools, pails, buckets or other receptacles containing stagnant water. They are not so abundant in sewage wate: The adults winter in barns, cellars, hollow trees and similar sheltered places, only the females living over.

A. punctipennis Say. Occurs throughout the State, but more commonly in the southern portions. Larvæ may be found from May to November; but are usually rare until after midsummer; after mid-September only stragglers remain. Breeds in almost any waters except on salt marshes.

A. quadrimaculatus Say-maculipennis of American authors. This is the species that has been convicted of transmitting malaria. It occurs throughout the State, but is rather more common in the northern counties. The general habits are like those of the preceding, but the larvæ occur also in more shaded areas, and occasionally in the brackish waters of the salt marshes.

A. crucians Wied. Occurs chiefly along the coast line from Elizabeth to Cape May, more common southwardly, and the larvæ breed chiefly on the salt marsh or on swampy areas not far inland. The species does not become obvious until mid-summer and remains until late fall. The inland points at which single examples have been taken are Manumuskin X, 21 (Dke), Delair (Seal) and Lahaway X, S (Brakeley).

A. barberi Coq. Bordentown VIII, 14, 16, adults (Brakeley); Chester IX, 6-11 larvæ (Dn). This species breeds exclusively in the water in tree holes and never gets far away from its breeding grounds.

\section{PSOROPHORA Desv.}

P. ciliata Fabr. Local throughout the State and rarely common as an adult. This is our largest species and lays its eggs in depressed 




\section{THE INSECTS OF NEW JERSEY.}

areas likely to be rann-filled. The larve develop in these temporary pools and feed upon other mosquito wrigglers. They are the giants of their lind, and if there is not sufficient food for all, they eat each other. Larvæ have been found from June to September 25, and adults from July 2 to September 30 .

\section{AEDES Meig.}

The species now referred to this genus are those species of what we have been calling "Culex," that do not lay their eggs in rafts or boatshaved masses. They may be laid singly or in little masses in the mud of lepressed areas, or on the surface of the water, sinking to the bottom and usually passing the winter in that stage, covered by water or unprotected in the mud.

A. sayi D. \& K. (Janthinosoma musica Say.) Locally common, chiefly in the northern sections of the State. The larve breed, as a rule, in heavily shaded woodland pools, and the adults do not leave the vicinity of their place of birth. They are ferocious biters, and sometimes in the Great Piece Neadow region are locally almost unbear. able. Larve have been found only from New Brunswick northward, June to September: adults have been taken also at Spring Lake VI, 30 , and Lakehurst VIII, 16.

A. jamaicensis Theob. Locally common, breeding in open lot pools, though isolated examples of the larve have been taken in woodland pools. We have only found it at Millburn, Newark, New Brunswick and Delair in July and August; but undoubtedly it is more generally distributed. The adult has never been found attacking man, and though a breeding place is not far from my house, I have never found examples on my porches.

A. discolor Coq. Delair, VI, 18, VII, 24, VIII, 15. Larre have been taken only by $\mathbf{M r}$. Seal in the one place on the dates mentioned, and we have not found it in any stage elsewhere. It is truly a rare species.

A. sollicitans Wlk. This is the common, banded-leg salt marsh mosquito. It breeds exclusively on the salt marshes in fresh, brackish or salt water and flies inland long distances, forming the predominating pest within its range-which means more than half the State-during the entire summer. From Barnegat Bay south larvæ begin to hatch in Narch, and adults are on the wing in April or May, and thereafter as many as ten broods may develop before November, when the last stragglers mature. In the more northern marshes larvæ do not usually appear until June, "cantator" replacing it as the early spring form. The eggs are laid in depressions in the marsh mud and must dry out before they can hatch. It is in this stage that the winter is passed.

A. tæniorhynchus Wied. Has the same habits as the preceding, but is not nearly so abundant and does not migrate so far. Occasionally it is quite numerous in the southern part of the State; but in some seasons it is not seen at all on the more northern marshes. 


\section{I8 REPOR'T OF NEW JERSEY STATE MUSEUM.}

A. sylvicola Gross. Larvæ were taken at Paterson in May, at New Brunswick May and June. Adults were taken also at Westville and Mount Holly, specimenș occurring near New Brunswick until VII, 28. This is rather a rare species, breeding only in pools in dense woodland, whose shelter the adults never leave. There is only a single spring brood, the late captures representing straggling survivors. This species was at first identified with "squamiger," which later proved to be different in habits and early stages.

A. niveitarsis Coq. Larva were found near Paterson, V, 9, 14, in a rocky, mountain pool, and the adults bred from them are the types of the species, no other examples of which have been since taken.

A. cantator Coq. Also a salt marsh breeder, occurring along the entire coast line, but much more abundant in the more northern ranges. It replaces "sollicitans" north of Barnegat Bay as the early spring form, and from larvæ which hatch in March or April the first brood comes early in May. After mid-summer it is much less numerous and generally replaced by "sollicitans." It has the same egg-laying and migrating habits as the latter species, and like it breeds until the meadows are frozen-larvæ being quite generally found under the ice when the pools freeze in early winter.

A. subcantans Felt. Occlirs throughout the northern parts of the State in woodland pools. There is only a single spring brood, larvæ appearing in March and maturiug in early May; but the adults linger until mid-summer. Larvæ have been actually found at or near Elizabeth, Newark, Arlington, Cranford, Millburn, Morristown and in the Great Piece Meadows. This species was at first believed to be identical with the European "cantans," but has been proved distinct by careful study.

A. abfitchii Felt. Has the same range as the preceding and much the same habits. It has been found a little further south, at New Bruns. wick, and the adults occurred as far north as Lake Hopatcong and Swartswood Lake. Mr. Grossbeck notes that, for breeding, both this and the previous species "select swampy woodland areas or hilly regions scattered over with large pools-small isolated pools being rarely inhabited by them." The adults are hard biters, but do not leave the woodland. This species was described by Mr. Grossbeck as "siphonalis" at about the same time that Dr. Felt described his species, but Dr. Felt's description was first published.

A. fitchii Felt. Very much like the preceding in appearance and probably in habit; but rare in New Jersey. Mr. Brakeley has taken larvæ at Lahaway and Mr. Grossbeck in the Great Piece Meadows, boti in April.

A. sylvestris Theob. Occurs throughout the State and throughout the summer, sometimes in considerable numbers; but rarely attempts to bite and does not enter houses. Larvæ appear in woodland pools early in April, but later occur in more open places-anything from a lot or even a clean gutter-pool to an overgrown swamp area serving to develop them. 


A. signifer Coq. Larvæ have been talien at Chester, IX, 5, XI, 17, Riverton IX, 8, Delair IX, 20, Lahaway IX. This species breeds normally in tree holes, though occasionally it resorts to barrels or old tubs; it has only been taken in late fall.

A. atropalpus Coq. This species breeds only in rock-pools. It has been taken in Maine and in Maryland, but not yet in New Jersey. It is almost certain that it occurs along the shores of the Delaware River near the Water Gap.

A. canadensis Theob. Throughout the State. The commonest of our woodland pool mosquitoes, larvæ hatching from over-wintering eggs before the ice is permanently off the surface. There is one heavy regular spring brood, but larva may be found in greater or less abundance throughout the season. Bites readily enough in the woods, but does not follow into the open and never enters houses.

A. dyari Coq. Culver's Lake V, 29, bred from pupa.

A. triseriatus Say. Taken in many localities in the northern half of the State; but undoubtedly occurs everywhere in it. Breeds normally in tree holes; but also occasionally in pails or other wooden recep. tacles. Larva have been found as early as April 18 (Paterson), as late as November 17 (Chester), and at all periods throughout the summer.

A. serratus Theob. Breeds in low, swampy woodland, and sometimes in mountain pools. Adults have been taken at Great Piece Meadow 1X, 17, New Brunswick VI, 23, X, 5, Cape May IX, 21. Larvæ have been found at Great Piece Meadow IX, 9, Orange MIs. VIII, 6, New Brunswick VII, 29, VIII, 13, IX, 3, 30.

A. dupreei Coq. Occurs in the same pools with the preceding and at the same time. It is a small, rare species; the adult does not bite humans and the larva is a bottom feeder that gets its supply of oxygen from the water itself.

A. abserratus Felt. Larve have been taken in the Orange Mts. IT, 20, and at New Brunswick $I V, 16$ to $V, 2$. It is probably the earliest of the spring species to mature, the larve rarely extending into May, and not appearing again later in the season. Breeds in low, swampy woodlands and in mountain pools.

A. trivittatus Coq. Quite generally distributed throughout the State; hardly common, but more abundant in the northern half. Larvæ from V, 8 to VIII, 12; adults from VII, 2 to IX, 3. Breed in unsheltered pools, associated with "sylvestris."

A. pretans Gross. Larva in the Great Piece Meadow IV, 19-V, 10; adults, Chester VII, 30, IX, 10, Great Piece Meadow IX, 13, Lake Hopatcong VII, 21, Trenton VII, 18. Mr. Grossbeck writes: “Taken rarely except in the Great Piece Meadows, where, in some years, it occurs in countless millions."

A. inconspicuous Gross. Larvæ taken on Garret Mt., Paterson, IX, 29, which produced adults $\mathrm{X}, 4,5$. They were found in a rock pool, and have not been found since. 


\section{REPOR'T OF NEW JERSEY STATE MUSEUM.}

A. aurifer Coq. Larvæ from III, 23-V, 10 at Lahaway, Arlington V, 9, Great Piece Meadows V. Adults from early May to late August, the specimens matured in May living throughout the summer and biting fiercely whenever they get a chance. They have been found in troublesome numbers at Lake Hopatcong, Springdale, Culver's Lake and Swartswood Lake. Breeds in woodland pools, the larger and more permanent being preferred.

A. pallidohirta Gross. Larvæ taken from a woodland pool on the Orange Mts.; adults emerged V, 19, 22. Not found since, nor elsewhere.

A. fuscus O. S. Occurs throughout the State rarely, and only in spring. It is a small species that does not attack man, and the larva occurs in pools, both woodland and open.

\section{CULEX Linn,}

As now restricted, this genus contains those species of mosquitoes that lay their eggs in boat-shaped rafts on the surface of the water. When at rest, the body is held parallel to the surface' on which the mosquito is placed-a character shared with the species of "Aedes" in distinction from the species of "Anopheles."

c. pipiens Linn. The "house" or "rainbarrel" mosquito. Common throughout the State throughout the year. Hibernates as an adult in cellars, basements, barns and other buildings, and begins breeding early in May. Breeds in pools and puddles of all kinds and wherever even a cupful of water remains for a week or ten days. Cisterns and manure pits offer equal attractions, and sewer basins in cities are favorite resorts. In general there is no water in which this species does not breed, if there are no natural enemies or adverse natural conditions.

C. restuans Theob. Similar in habit and appearance to the preceding, but less

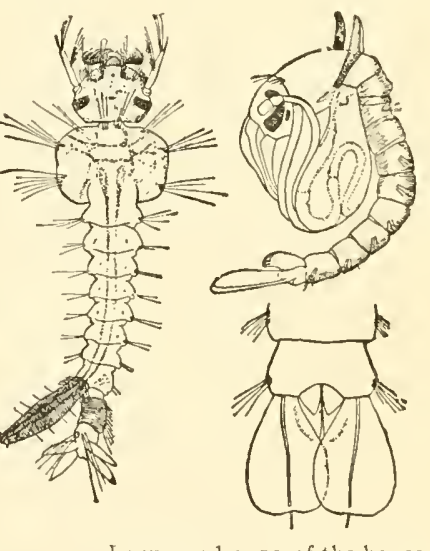

Larva and pupa of the house mosquito.

Fig. 296. abundant, and the larva on the whole prefers cleaner water. Never theless, it does sometimes occur in dirty, or even foul water.

c. salinarius Coq. Breeds only on the salt marshes from the last days of May to the end of November. The adult resembles the common "house mosauito" and has similar habits.

C. territans Wlk. Occurs throughout the State, breeding continuously from April to October, sparingly at first, more abundantly later in the season. The larvæ are essentially clean water forms, and seem to 


prefer the more permanent bodies of water, but they are occasionally found in puddles and rarely in rain barrels.

c. saxatilis Gross. Larre occurred in a rock-bottomed pool on the Garret MIt., Paterson, Aug. 31, and adults emerged the same day and the one following; it has not been met with since.

c. melanurus Coq. The larræ breed and winter in cold spring pools in Sphagnum swamps, among the bottom material. They have also been found in early August with the egg boat and may breed all summer. Thus far found only at lahaway.

\section{COQUILLETTIDIA Dyar.}

C. perturbans Wlk. Local throughout the State and sometimes very common. Adults appear in May and continue into September. Eggs are laid in rafts in overgrown swamps, and the larve work into the bottom mud, attach themselves to grass roots, and there remain until the following year. Larval growth is very slow, and the adult is very long lired and a fierce biter. It comes freely to porches, and is not backward in entering houses, making it locally a first-class pest.

\section{URANOTAENIA Arrib.}

U. sapphirina O. S. Local, but probably found throughout the State. Larvæ have been found in the Great Piece Meadows VIII, 10, Irvingtou IX, 5, Trenton VIII, 5, Metedeconk Neck IX, 23, Lahaway VI, Cape May. Breeds in open swamp areas well orergrown with floating regetation, the eggs laid in boat-shaped masses. The arlult is a small insect marked with metallic blue scales and does not bite.

\section{WYEOMYIA Theob.}

W. smithii Coq. Breeds in the leaves of pitcher plants, "Sarracenia," wherever these occur in the State. The adult is a small insect that does not bite and lays its eggs in the leaves, fastened to the sides when they have no water, or on the surface when they are full. Larvæ may be found at all times of the year, the winter being passed in that stage, sometimes active, in mild weather, sometimes frozen solid. The first adults mature late in May.

\section{Family CORETHRID五.}

The members of this family have until recently been included with the mosquitoes; but in their light colors and generally weak appearance they come nearer to the "Chironomida." The mouth parts are not extended, and are not furnished with lancets, so that they cannot bite. Except in the genus "Corethrella" the known larvæ of our species are not dependent upon atmospheric air. They live in the water, maintaining a horizontal position some distance below the surface, and are so transparent as to be almost invisible. They are predatory in habit.

$$
46 \mathrm{IN}
$$




\section{REPOR'T OF NEIV JERSEY STATE MLSEUM.}

\section{SAYOMYIA COQ.}

S. albipes Johann. Larvæ have been taken in the Great Piece Meadows, at Paterson IV, VII, IX, Arlington V, Newark VIII, Trenton, Delair VII, and the winter is apparently passed in that stage. Breeds in the more permanent woodland pools, but is also found in more open water.

S. punctipennis Say. Chester VIII, 1, Delair IX, 17, Riverton V, 19.

\section{CORETHRA Meig.}

C. cinctipes Coq. Lake Hopatcong VII, 22, Great Piece Meadow IV, 10, Paterson V, 6, Neiv Brunswick V, 3, Lahaway III, 28-IV, 26-all larvæ. This is a common spring species breeding in large woodland pools, the July specimen being a straggler. The larva is predaceous, and when food is scarce becomes cannibalistic.

c. lintneri Felt. Larvæ taken at Millburn in May were not recognized as distinct from the preceding until the adults emerged a few days later.

\section{CORETHRELLA Coq.}

C. brakeleyi Coq. This is a very rare species which breeds in cold spring pools and sphagnum swamps. Larvæ have been taken by Mr. Brakeley at Lahaway in almost every month of the year, and beside that it has been taken only at Delair, by Mr. Seal, and at Trenton by Mr. Grossbeck.

\section{Family MYCETOPHILID正.}

These are fungus-gnats, also resembling mosquitoes or midges, but the antennæ are not verticillate or furnished with whorls of hair. In the male the abdomen ends in a forceps-like process, and in the female in a pointed ovipositor. There are other structural differences to characterize the family, but these are not easily seen except by the student. The larvæ are feeders in fungus and in decaying vegetation generally, and might be considered at worst harmless were it not that they attack cultivated mushrooms. The larvæ are white, slender, have a black head, and often live in large colonies. Some of them have the curious habit of forming great rope-like masses when ready to enter the pupal stage. sometimes travelling considerable distances to find a suitable place.

Where they occur in mushroom beds, fumigating frequently with tobacco or pyrethrum to kill the adults inside, and keeping all windows closely screened to prevent the entrance of specimens from outside, is the only practical measure known to me.

\section{PLESIASTINA Winn. (SYMMERUS WIk.)}

P. annulata Meig. Riverton IV, 19. 




\section{ASYNDULUM Latr.}

A. montanum Roeder. Dunnfield, Del. Water Gap VII, 11, 15.

\section{CEROPLATUS BOSC.}

C. clausus Coq. New Brunswick (Sm).

\section{PLATYURA Meig.}

P. diluta Loew. Dunnfield, Del. Water Gap VII, 11, 15.

P. mendosa 1.oew. Clementon V, 30.

P. tæniata Winn. Dunnfield, Del. Water Gap VII 12.

P. elegans Coq. Orange MIts., Shark River VII, 12.

P. inops Coq. Dunnfiel.I, DeI. Water Gap VII, 8, 12.

P. melasoma Loew. Dalaware Water Gap VIl, 12.

P. subterminalis Say. Riverton VIII, 11 (Jn); Lucaston IX, 2 (Dke); Trenton VIII, 23 (Hk).

P. fascipennis Say. DaCosta VIII, 9 (Dlie).

\section{SCIOPHILA Meigen.}

S. littoralis Say. Del. Water Gap VII, S, 13. Dover VI, 17, Merchantville VI, 28, Westville VIJ, 21, Clementon VI, $3(\mathrm{Jn})$; New Brunswick VII, $20(\mathrm{Sm})$.

\section{NEOEMPHERIA O. S.}

N. balioptera Loew. Princeton VII, 21, Westville VIII, 23.

N. nepticula Loew. Mercliantville VI, 28.

N. didyma Loew. Woodbury VI, 7 (Jn); Lucaston IX, 12 (Dke).

\section{POLYLEPTA Winn.}

P. tibialis Coq. Dunnfield, Del. Water Gap VII, 8, Westville VI, 6.

\section{ACNEMIA Winn.}

A. flaveola Coq. Dunnfield, DeI. Water Gap VII, 11.

\section{SYNTEMNA Winn.}

S. polyzona Loew. Clementon VI, 3.

\section{BOLETINA Stæger.}

B. tricincta Loew. Dunnfield, Del. Water Gap VII, 15, Dover VII, 17, Clementon VI, 3.

B. grœnlandica Stæg. Forest Hill III, IV (IVdt); IIerchantville III, 12 $(\mathrm{Vk})$. 


\section{LEPTOMORPHUS Curt.}

L. parvulus Coq. Dunnfield, Del. Water Gap VII, 12.

L. walkeri Curtis. Trenton VIII, 23 (Hk).

\section{EPICYPTA Winn.}

E. punctum Stann. Dunnfield, Del. Water Gap. VII, 15.

E. pulicaria Coq. Riverton IV, 19 .

\section{DOCOSIA Winn.}

D. dichroa Loew. Malaga VI, 1, Iona V, 10 (Dke).

\section{NEOGLAPHYROPTERA O. S.}

N. bivittata Say. Ft. Lee V (Lv); Princeton VII, 21, Jamesburg VII, 4, Atco VII, 12 (Jn).

N. opima Loew. Dover VI, 17, Merchantville VI, 28.

N. subiunata Loew. Merchantville VI, 28.

N. ventralis Say. (Leja) Dunnfield, Del. Water Gap VII, 8, 15.

\section{TRICHONTA Winn.}

T. perspicua V. d. W. Riverton IV, 16.

\section{EXECHIA Winn.}

E. analis Coq. Dunnfield, Del. Water Gap VII, S.

\section{MIYCETOPHILA Meigen.}

M. punctata Meig. Riverton III, 20-IV, 8 (Jn); Merchantville IX, 16 (Dlie).

M. sigmoides Loew. Del. Water Gap VII, S, Riverton III, 6.

M. contigua Walk. Riverton III, 6, IX, 9.

M. obscura Walk. Trenton IV, 19 (Hk); Riverton III, 6, Clementon Vl, 16.

M. vitrea Coq. Dunnfield, Del. Water Gap VII, 12.

M. discoidea Say. New Brunswick VI, 11 (Coll).

\section{DYNATOSOMA Winn.}

D. scalaris Loew. (Mycetophila) Del. Water Gap VII, 8, Riverton III, 6, Clementon V, 10.

\section{MACROCERA Meig.}

M. clara Loew. Dunnfield VII, S, Clementon VIII, 9 (Jn).

M. formosa Loew. Del. Water Gap VII, 12, Merchantville V, 2S, Clementon VIII, 9. 


M. nebulosa Cog. Clementon VI, 3, VIII, 9.

M. hirsuta L.oew. Dunnfield, Del. Water Gap VII, 11.

M. inconcinna Loew. Orange Mts. VIII (Wdt).

\section{EUGNORISTE Coquillett.}

E. occidentalis Coq. Trenton VIII, $3(\mathrm{Hk})$.

\section{SCIARA Meigen.}

S. fulvicauda Felt. Types, Atlantic Co., from decayed blackberry roots $(\mathrm{Sm})$.

s. pauciseta Felt. New Brunswick, types from decaying potatoes IX (Sm).

s. multiseta Felt. New Brunswick, types bred from mushrooms $V$, and this is the common species in mushroom cellars with us (Sm).

S. polita Say. Clementon $\mathbf{V}, 30$.

S. inconstans Fitch. Newark, New Brunswick THI, 7 (Coll); Riverton II, 26, Clementon VI, 3.

S. abbreviata Walk. Anglesea VII, 12 (Sm).

S. fuliginosa Fitch. Palisades (IN); $N$. Woodbury VI, 17, Iona VI, 2 (Dlie).

S. femorata Say. Fort Lee IV, V (Lr).

\section{HESPERODES Coquillett.}

H. johnsoni Coq. Delaware TVater Gap VII, 12.

\section{Family CECIDOMYIIDE.}

Small, slender, mosquito-like flies with broad wings, long slender antennæe with cylindrical or bead-like joints, the males often with whorls of long hair on the segments, whence they are known as verticillate. On the whole the iusects are fragile in appearance, slow in flight, and they are popularly known as "gall-gnats" or "gall-midges," because the larvæ of many species produce abnormal growths or galls on a great variety of regetation. These larva are small, elongate-oval legless grubs, bluntly pointed at both ends, often with a chitinous process, known as a breastbone, on the under side, near the anterior end.

Some of the species belonging here are among the most destructive of those in the order, and the injury caused by them is of the most diverse character. In some cases there is a true, gall-like swelling of the tissue; in others it is a characteristic crippling or folding of a leaf or of a growing tip, or even a mere swelling of the tissue. Some species produce no visible swelliugs or distortions at all, and some feed in or on seeds, causing rather a shrivelling than a swelling. Much attention has recently been paid to these insects by Mr. William Beutenmuller, of the American Museum of Natural History, who has been good enough to pre- 


\section{REPORT OF NEW JERSEY STATE MUSEUM.}

pare the systematic part of this list, and by Dr. E. P. Felt, State Entomologist of New York, and a great many new species have been described, some of which will undoubtedly be found in New Jersey. Mr. Beutenmuller has in general included only actual records, mostly of his own collecting, and the notes on food plants, etc., are his, unless otherwise credited. In some cases galls have been described, of which the makers are yet unknown, and these are separately listed. Dr. Felt has kindly supplied additional notes from his breedings and studies, but I have not been able to incorporate all his systematic suggestions.

As the species differ so widely in habit, so the methods of dealing with them are diverse. Insecticides are available in the smallest number of cases, and usually it is some change in cultural method that must be relied upon to prevent injury.

\section{LASIOPTERA Meigen.}

L. carbonifera Felt. Makes galls on leaves of goldenrod; common and g. d. (Bt). The gall was first described by Osten Sacken, and the name is so credited in the last edition.

L. cornicola Beut. Ft. Lee district. Galls on trunks and branches of dogwood, "Cornus stolonifera" IX-VI (Bt); Staten Island (Ds).

L. cylindrigallæ Felt. Ft. Lee district IV, V (Bt); Staten Island, gall elongate on stems of goldenrod IV $(\mathrm{Ft})$.

L. farinosa O. S. Throughout the State, locally common, galls on leaves of blackberry, "Rubus villosus" VIII-X (Bt). See in this connection "L. nodulosa" Beut.

L. humulicaulis Felt. New Jersey district (Bt); gall on stem of hop (Ft).

L. linderæ Beut. Ft. Lee district and elsewhere, sometimes common; galls on branches of spice bush, "Lindera benzoin" $\mathrm{X}$-VI (Bt); Staten Island, from irregular sub-cortical gall.

L. Iycopi Felt. Plainfield; gall on bugleweed "Lycopus virginicus" IX-V (Bt).

L. nodulosa Beut. Ft. Lee district; galls on branches of blackberry, "Rubus villosus" $\mathrm{X}$-VI (Bt). This is the species referred to in the last edition as "farinosa." I have found it, locally, from New Brunswick southward; sometimes also on dewberry, but never causing actuàl injury in cultivated fields.

L. sambuci Felt. Ft. Lee district; galls on stems of elder, "Sambucus canadensis" IX-VI (Bt); Staten Island (Ds).

L. solidaginis O. S. New Jersey district; larva probably inquilinous in galls on Solidago $(\mathrm{Bt})$.

L. tumifica Beut. Ft. Lee district; gall on stalk of golden-rod, "Solidago rugosa" IX-VI (Bt); Staten Island, from eccentric sub-globular stem gall (Ft).

L. vernoniæ Beut. Ft. Lee district and elsewhere; galls on leaves of ironweed, "Vernonia noveboracensis" IX (Bt); Staten Island IX (Ds). 


L. viburnicola Bent. Ft. I.ee district; galls on branches of arrowwood, "V'iburnum dentatum" X V'l (Bt); Staten Island (Ft).

L. vitinea Felt. Staten Island V'I, 15; obpyriform, slightly curved sall on leaf petiole of grape $(\mathrm{Ft})$.

L. vitis O. S. Thronghont the State, local on grape, V, VI (Sm); makes swellings on stems and leaf galls of wild grapes $(\mathrm{Bt})$.

\section{CHORISTONEURA Rübs.}

C. hibisci Felt. Staten Island IV; wall on stem of marshmallow. "Hibis. cus moschatus" (Ft).

C. eupatorii Felt. Staten Island V; oval gall on stem of "Eupatorium" $(\mathrm{Ft})$.

\section{RHABDOPHAGA Westw.}

R. batatas Walsh. Montclair, Ft. Lee district; galls on twigs of "Salix discolor" and allied species of willow (Bt): Staten Islancl (Ds).

R. ramuscula Felt. Staten Island, from willow twigs showing little or no swelling ( $\mathrm{Ft}$ ).

R. brassicoides Walsh. Greenwood Lake. Montclair, Ft. Lee district VII-IX, galls on brariches of willow (Bt).

R. rigida O. S. Mlontclair, Ft. Lee district, galls on low willows (Bt); Staten Island (I)S).

R. salicifolia Felt. New Jersey distriet (Bt); bred from a pouch gall on "Spiraea salicifolia" VI (Ft).

R. strobiloides O. S. Del. Water Gap VI (Jn); Greenwood Lake, Montclair, Orange Mts., Englewood, Ft. Lee and g. d., galls on tip of branclies of low wiliows VliI-Y (Bt).

\section{DASYNEURA Rond.}

D. gleditschiæ O. S. Sometimes common locally on leaves of honey locust. "Gleditschia triacanthos" VI (Bt); New Brunswick (Sm).

D. grossulariz Fitch. New Jersey district; larva in gooseberries (Bt).

D. hirtipes O. S. Ft. Lee district, Carlstadt; gall on fragrant goldenrod, "Solidlago graminifolia" VI, VII (Bt).

D. leguminicola Lint. The clover-seed midge; more or less common throughout the State; but scarcely injurious becanse not much cloverseed is raised, and the value of the crop for hay is not affected. If clover-seed is wanted it is necessary to cut an early crop of flowers for hay and make seed from the later flowers.

D. coryli Felt. Reared from corrugated leaves of "Corylus" at West Nyack, N. Y. (Ft).

D. rhois Coq. New Jersey district: gall on roots of poison ivy (Bt).

D. pseudacacia Fitch. Ft. Lee district (Bt); New Brunswick, common on leaves of locust, "Robinia pseudacacia" (Sm). 


\section{REPORT OF NEW JERSEY STATE MUSEUM.}

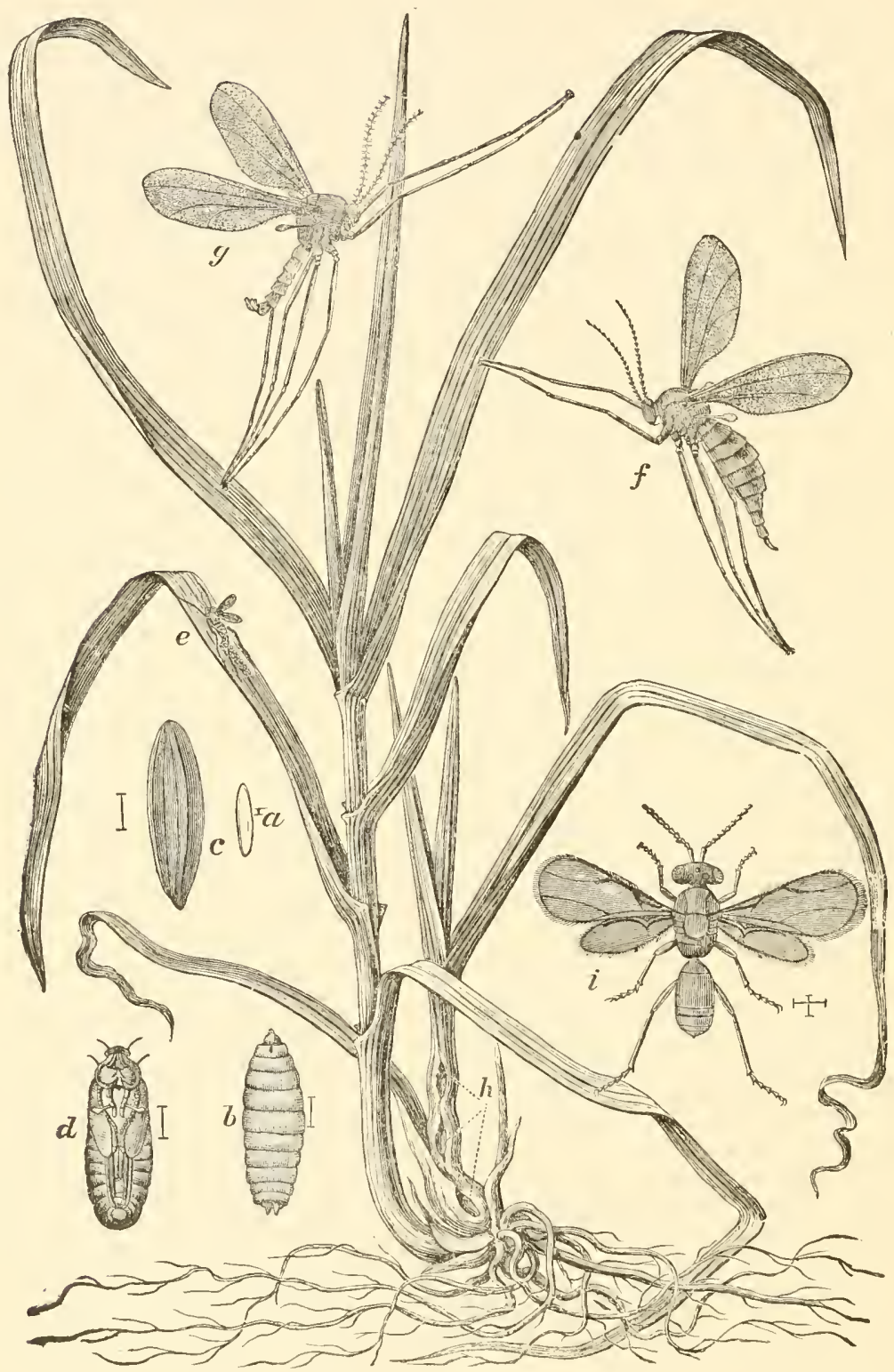

Fig. 297.-The Hessian fly, Mayctiola destructor: on the left a healthy stalk of wheat and on the right one infested at $h$ by the "fly," showing galls; $a$, egg; $b$, larva; $c$, flaxseed; $d$, pupa; all very much enlarged; $c$, fly ovipositing on leaf, natural size; $f$, female; $g$, male fly, much enlarged; $i$, the parasite, Merisus destructor; also much enlarged. 


D. serrulatæ O. S. Montclair, Ft. Lee district, Lakehurst, common locally, gall on bud of alder, "Alnus serrulatus" IX-VI (Bt); Staten 1sland (Ds).

D. solidaginis Loew. Common throughout the State; gall on goldenrod (Bt); Clementon VIII (Jn).

\section{ARNOLDIA Kieffer.}

A. fraxinifolia Felt. Newfoundland VII, 25, gall on young ash leaflets (Ft).

A. vitis Felt. New Jersey district (Bt); from galls of "Lasioptera vitis" (Ft).

\section{ASPHONDYLIA Loew.}

A. azaleæ Felt. New Jersey district (Bt); galls on buds of azalea (Ft).

A. conspicua O. S. New Jersey district; gall on stem of cone-flower, "Rudbeclía triloba" VIII, IX (Bt).

A. globulus O. S. New Jersey district; gall on stem of sun-flower, "Helianthus gigantea" VIII, IX (Bt).

A. patens Beut. New Jersey district; gall on aster VIII, IX (Bt).

A. solidaginis Beut. Montclair, Ft. Lee district, gall on lcaf of goldenrod (Bt).

\section{RHOPALOMYIA Rübs.}

R. fusiformis Felt. Ft. I.ce district; galls on leaves and flowers of fragrant goldenrod, "Solidago graminifolia" VIII, IX (Bt).

R. capitata Felt. Common at West Nyack, N. Y., just north of the New Jersey line (Ft).

R. inquisitor Felt. Common at West Nyack, N. Y. (Ft).

R. major Felt. Staten Island $V, 31$ (Ft).

R. anthophila O. S. Staten Island (Ft).

\section{MAYETIOLA Kieffer.}

M. destructor Say. The "Hessian fly." Sometimes very destructive north of the red shale line. The method usually adopted to avoid injury is to plant as late as is safe. In the sonthern counties it may be delayed until after nid-September and injury is rare; in the northern counties planting soon after September 1st is ustal and this is dangerous. The flies usually emerge after the early Septem. ber rains and are in the fields for two weeks thereafter. Sometimes a scant early seeding is made as a trap, and this is plowed under about September 10 and the real crop put in.

\section{CONTARINIA Rond.}

C. pyrivora Riley. The "pear midge." Infests pear, preferring the Lawrence, causes an irregular lumpy growth, the larvæ eating out the core in June. This species has been gradually worked out and now maintains itself only in a few places near New Brunswick and Newark.

c. tritici Kirby. Locally and seasonally abundant north of the red shale in wheat kermels. Not really injurious since 1889 . 


\section{REPOR'T OF NEW JERSEY STATE MUSEUM.}

\section{CECIDOMYIA Meigen.}

C. annulipes Walsh. New Jersey district, inquilinous in galls of "Rhabdophaga strobiloides" (Bt).

C. anthophila O. S. New Jersey district; gall on golden-rod (Bt).

C. atricornis Walsh. New Jersey district; inquilinous in gall of "Rhabdophaga strobiloides" (Bt).

c. bulla Wash. New Jersey district; gall on leaves of wild sunflowers "Helianthus decapetatus" and "divaricata" VIII, IX (Bt).

C. caryæ O. S. Ft. Lee district; galls on leaves of hickory (Bt).

C. cerasifolia Felt. Newfoundland IX, 4; galls on leaves of choke cherry (Ft).

C. clavula Beut. Orange Mts., Nontclair, Ft. Lee district, common on the terminal twigs of dogwood, "Cornus florida" VIII, IX (Bt); Staten Island (Ds).

C. helianthi Brodie. Staten Island VIII, IX (Ds).

C. Iysimachiæ Beut. Carlstadt, Ft. Lee district and elsewhere; galls in buds of loosestrife, "Lysimachia" VI (Bt); Jamesburg and throughout south Jersey about and on cranberry bogs; this seems to be the species which I believed identical with that infesting cranber'y $(\mathrm{Sm})$.

C. meibomiæ Beut. Staten Island (Ds); galls on tick-trefoil, "Meibomia" sp., VIII, IX (Bt).

C. meibomiifoliæ Beut. Carlstadt; galls locally common VIII, on buds of "Meibomia canadensis" (Bt).

C. myrica Beut. Carltsadt; galls locally common on "Myrica cerifera" (Bt).

C. nyssæcola Beut. Ft. Lee district and elsewhere, sometimes very common, galls on the edges of leaves of sour-gum, "Nyssa sylvatica" VI (Bt).

C. orbitalis Walsh. New Jersey district; inquilinous in galls of "Rhabdophaga batatas," "strobiloides" and "brassicoides" (Bt).

c. piluize Walsh. Common throughout the State; galls on leaves of red, scarlet, black, scrub, black-jack and pin oak, "Quercus rubra," "coccinea," "velutina," "nana," "marylandica" and "palustris" VII-X (Bt).

C. pudibunda O. S. Ft. Lee district; galls on lèaves of hornbeam, "Carpinus caroliniana" VI, VII (Bt).

C. resinicola O. S. Lakehurst and the pine barrens generally VIII, IX (Bt).

C. rudbeckiæ Beut. New Jersey district; galls on flower heads of coneflower, "Rudbeckia hirta" VIII (Bt).

C. seminivora Beut. Plainfield (Mill); gall is a malformation of the seed capsule of apetalous or cleistogamous flowers of stemless or acau. lescent violets, "Viola cucullata," "palmata," "affinis," "septentrionalis" VI-X (Bt). 




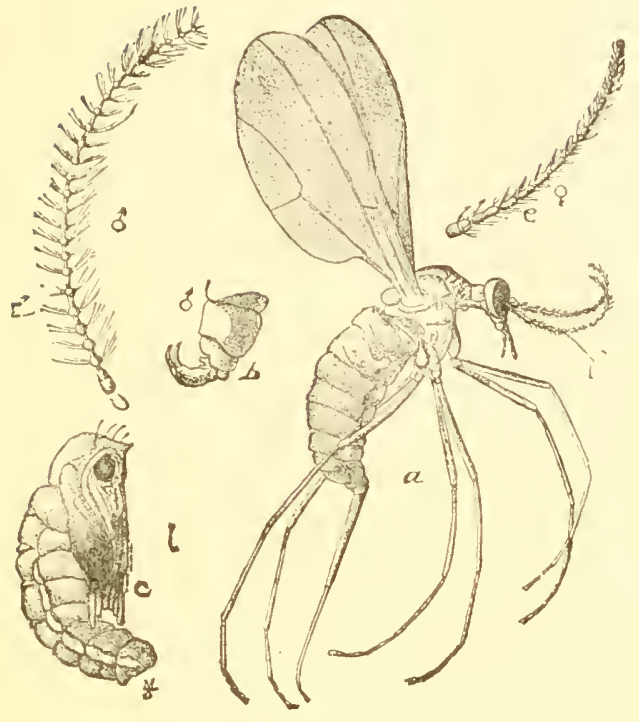

Fig. 298 .
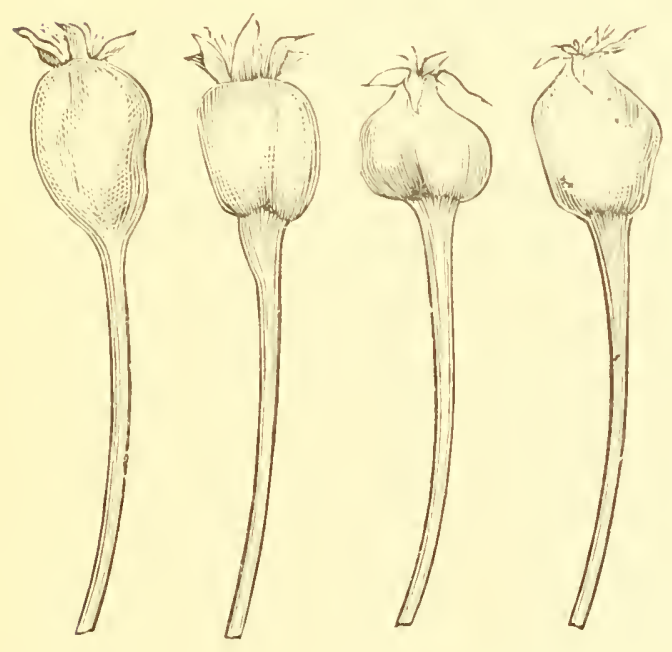

Fig. 300.

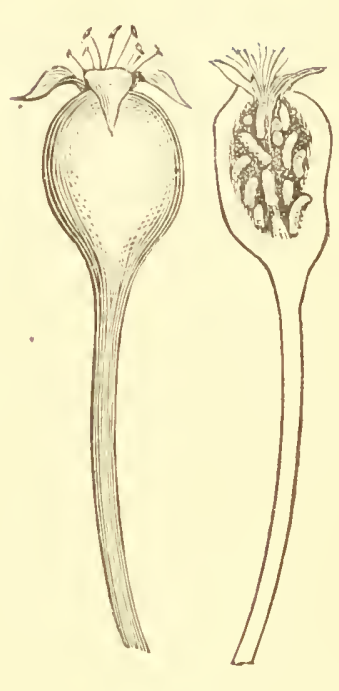

I*ig. 299.
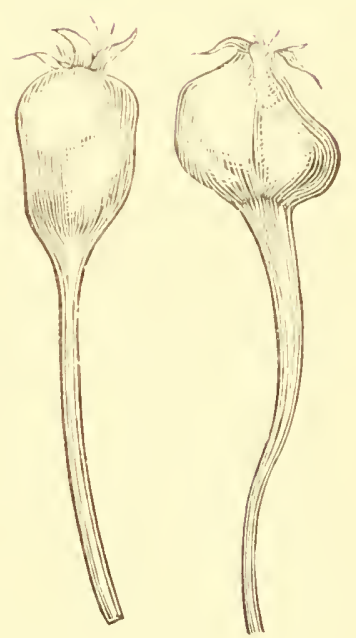

Fig. 298.- Pear midge, Contarinia pyrizora: $a$, female adult; $c$, pupa, both enlarged; all other references to structural details.

Fig. 299. - A sound pear and one infested by the larve of the pear midge.

Fig. 300.-A series of pears infested by the midge, showing distortions caused by larvæ. 
c. thurstoni Brodie. New Jersey district; galls on sunflower, "Helianthus divaricata," VIII, IX (Bt).

C. verbenæ Beut. Ft. Lee district, locally common; galls on leaves of nettle-leaved Vervaiu, "Verbena urticifolia" VI, VII (Bt).

C. ulmi Beut. Carlstadt, Ft. Lee district, sometimes common; galls on leaves of elm, "Ulmus americana," VI, VII (Bt).

C. oxycoccana Johns. (vaccinii Sm., not O. S.) Infests the terminal growth of the cranberry, throughout South Jersey; locally known as the "tip-worm" and sometimes injurious (Sm). Dr. Felt says it is a "Dasyneura."

\section{CECIDOMYIA KNOWN BY THEIR GALLS AND LARV A ONLY.}

C.? angelicæ Beut. Middlesex Co. (Mill); gall on stalk of "Angelica villosa" IX, X (Bt).

c.? bœhmeriæ Beut. New Jersey district; gall on stalk of false nettle, "Bœhmeria cylindrica" IX (Bt).

C. brachypteroides O. S. Lakehurst and in the pine barrens generally; galls on the leaves of scrub pine, "Pinus inops" (Bt).

C. caryæcola O. S. Riverton IX (Jn); common everywhere, galls on leaves of hickory VIII-X (Bt).

C.? collinsoniæ Beut. New Jersey district; galls on leaves of horse balm, "Collinsonia canadensis" VIII, IX (Bt).

C. coryloides Walsh. New Jersey; galls on stems of wild grapes, "Vitis riparia" and "cordifolia" (Bt).

C. citrinæ O. S. Ft. Lee district; galls on the tips of twigs of basswood, "Tilia americana," VIII, IX (Bt).

C. cynipsea O. S. New Jersey district; galls on leaves of hickory VIII-X (Bt).

C. deserta Patt. New Jersey district; galls on hackberry, "Celtis occidentalis" (Bt).

C.? eupatorifloræ Beut. Ft. Lee district; galls in flower heads of "Eupatorium ageratoides" IX (Bt); Staten Island IX (Ds).

C. erubescens O. S. Ft. Lee district; galls on leaves of red oak, "Quercus lubra," V, VI (Bt).

C. holotricha O. S. Throughout the State on leaves of hickory (Bt); Staten Island (Ds): Riverton IX (Jn).

C. impatientis O. S. New Jersey; galls on "Impatiens pallida" VIII, IX (Bt).

C. inopis O. S. Staten Island (Ds); Riverton VII, IX (Jn); throughout the pine barrens generally; galls on the leaves of scrub pine, "Pinus inops."

C. liriodendri O. S. Common throughout the State; galls on the leaves of tulip tree "Liriodendron tulipifera."

c. majalis O. S. New Jersey; galls on leaves of pine oak, "Quercus palustris" (Bt). 


C. niveipila O. S. Ft. Lee, galls on young leaves of red oak, "Quercus lubra," V, YI (Bt); Staten Island (Ds); Riverton (Jn).

C. nuicola O. S. New Jersey; in the husks of hickory nuts (Bt).

C. pellex O. S. Ft. Lee district; galls on leares of ash, "Fraxinus," T, VI (Bt).

C. ocellaris O. S. Throughout the State; galls on leares of red maple, "Acer rubrum," V, VI (Bt); Staten Island VI (Ds).

C. persicoides O. S. Ft. Lee district; galls on the under side of hickory leaves VIII, IX (Bt); Chimney Rock, Bound Brook, New Brunswick (Sm).

C. poculum O.S. Common throughout the State; galls on leaves of white oak, "Quercus alba," VIII-X (Bt); the "oak-spangle" of Fitch and a very characteristic structure.

c. pomum Walsh \& Riley. Throughout the State in early summer on various species of grape, wild and cultivated; a very fleshy and often reddish discolored gall on vines, leaf-stalks and even tendrils; sometimes single, sonetimes with a number of cells. Often attracts attention, but is rarely injurious and disappears before mid-summer.

C.? pustuloides Beut. Ft. Lee, Lakelurst; galls on red, scarlet, black, scrub and black-jack oak, "Quercus rubra," "coccinea," "velutina," "nana" and "marylandica," IX (Bt).

C.? racemicola O. S. Plainfiell (Nill); galls amoug the racemes of golden rods, "Solidago canadensis," "puberula" and "serotina" IX (Bt) ; Staten Island (Ds).

C. salicifoliæ O. S. New Jersey; gall on "Spiræa salicifolia" (Bt).

C. sanguinolenta O. S. Ft. Lee district and elsewhere, common; galls on the leaves of hicliory VI, VII (Bt); Staten Island (Ds).

C. serotinæ O. S. Greenwood Lake, Montclair, Ft. Lee district; gall on twig of wild cherry, "Prunus serotina," $\mathrm{V}$, VI (Bt): Staten Island (Ds).

C.? triadeni Beut. Middlesex Co. (Mill): gall on stalli of marsh St. John's-wort, "Triadenum virginicum," IX (Bt).

C. tubicola O. S. Common almost everywhere in the State; galls on the leaves of hickory TIIl, IX (Bt); Riverton IX (Jn); Jamesburg, Lahaway $(\mathrm{Sm})$.

C. tulipifera O. S. Short Hills; galls on the ribs of leaves of tulip tree, "Liriodendron tulipifera," VIII, IX (Bt).

C. umbellicola O. S. South Orange, from galls among the umbels of elder, "Sambucus racemosa" (O. S.); Ft. Lee district, on common elder, "S. canadensis," VI (Bt): Staten Island (Ds).

C. verrucicola O. S. Little Falls, Staten Island (Ds); Ft. Lee district; galls on leaves of basswood, "Tilia americana," VII-IX (Bt); New Brunswick and frequently elsewhere in the State $(\mathrm{Sm})$.

C.? vaccinii O. S. Dover, Morris Plains, Clementon (.Jn); galls on the underside of leaves of huckleberry, "Vaccineum stramineum," IX, X (Bt). 


\section{3+ REPOR'T OF NEW JERSEY STATE MUSEUM.}

C. viticola O. S. Ft. Lee district; galls on leaves of wild grape (Bt); Staten Island (Ds); Vincentown (U S Ag).

\section{Family BIBIONIDE.}

Loose-jointed, ungainly fies of moderate size, with long, stout legs, body often clothed with long hair, antennæ many jointed but short and stout, mouth parts a little produced. There is often considerable difference between the sexes, and in some cases the females have a ridiculously small head. From the very early appearance of some species they are called "March flies," and sometimes they occur in orchards in numbers so great as to attract attention.

The larvæ are cylindrical, footless grubs, and "feed on excremental or regetable substances, especially on the roots of grass." They have not been, thus far, injurious in New Jersey.

\section{PLECIA Wied.}

P. heteroptera Say. Caldwell (Cr); Jamesburg (Sm); Lucaston IX, 4, Manumuskin X, 21 (Dke).

\section{BIBIO Geoff.}

B. albipennis Say. Caldwell (Cr); Newark (Sm); Westville V, 19, Clementon V, 30 (Jn); Manumuskin $\mathrm{V}, 21$ (Dke).

B. pallipes Say. Husted V, 21 (Coll); Jamesburg VII, 4, Riverton $\mathrm{V}, 1$.

B. femorata Wied. Caldwell (Cr); Newark V (Sm); Riverton $\mathrm{V}$, 1 (Jn); National Park V, 6 (Dke).

B. xanthopus Wied. Caldwell $(\mathrm{Cr})$, Riverton IV, 30.

B. longipes Loew. Palisades (Lv); Delair, Riverton, Wenonah, Lucaston, common X, XI (Dlie).

B. slossonæ Ckll. (gracilis Walk. not Unger.) Clementon $\mathrm{X}, 11$ ( $\mathrm{Hk}$ ).

\section{DILOPHUS Meig.}

D. breviceps Loew. Toms River V, 30 (Dke); Westrille V, 19, Clementon V, 9, VI, 16.
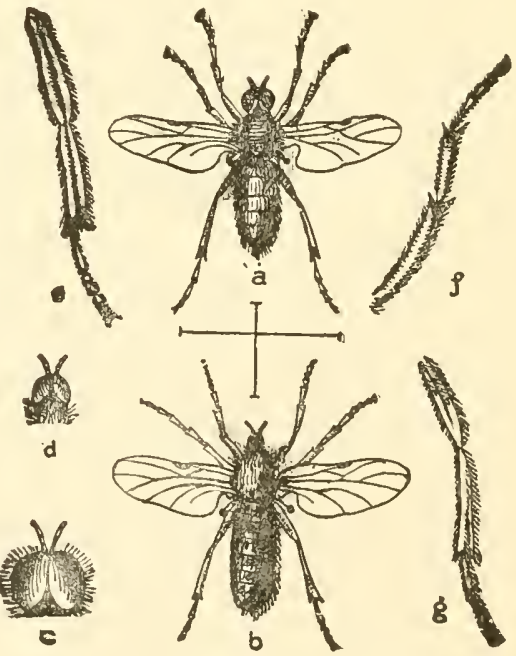

Fig. 3or.-Bibio albipennis: $a$, male; $c$, its head; $b$, female; $d$, her head; all enlarged. Other references to structural details. 


D. dimidiatus Loew. Avalon VI, 8 (Jn); Anglesea V (div); Cape May $1 \mathrm{x}, 21$ (Dke).

D. thoracicus Say. Forest Hill IX (Wdt); Blackwood VI, 8 (Jn).

\section{SCATOPSE Geoffroy.}

S. notata Linn. Clementon $\mathrm{r}, 9$ (Jn); Glassboro $\mathrm{V}, 19$ ( $\mathrm{Hk}$ ).

s. pygmæa Loew. Riverton VII, 31, IX, 9.

S. atrata Say. Riverton IV, 23.

\section{EUPITENUS Macq.}

E. ater Macq. Riverton IV, 9 (CG).

\section{Family SIMLLID.7:.}

Rather undersized chmky flies, known as "black flies," dark in color, the thorax well developed and somewhat produced forward so as to partially conceal the small head from above. Though the head is small in proportion to the insect, the mouth parts are exceedingly well developed and furnished with a formidable array of lancets for puncturing and blood-sucking. The wings are short and broad, the venation obscure except along the front margin.

These flies are horrible pests local ly, not so much in our State as in some others west and north, the "buffalo gnat" of the Mississippi Valley region and "black fly" of the north woods being excellent examples.

In New Jersey some species are pests in the Orange Mountains and northward, getting into the ears of horses, or even occasionally of man.

The larvæ are aquatic and live in runuing water.

\section{SIMULIUM Latr.}

S. venustum Say. "Black fly": Del. Water Gap VII, 11, Clementon V. 30 (Jn); Orange Mits. Caldwel? VII (Cr); Lucaston IX, 3 (Dke).

S. invenustum Walk. Passaic (U S $\mathrm{Ag})$; Orange $\mathrm{Mlts}$. (Sm), Clementon IV, $15(\mathrm{Jn})$; Manumuslin IV.

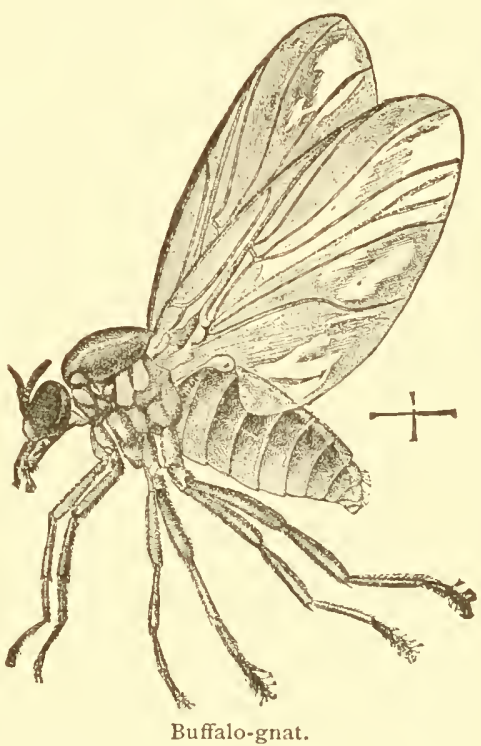

Fig. 302 . 28 , Iona IV, 20 (Dke).

S. vittatum Zett. Orange Mts. (Sm).

S. meridionale Riley. Passaic (U S Ag); Riverton VII, 6, X, 20.

S. bracteatum Coq. Clementon V, 30 . 


\section{REPORT OF NEW JERSEY STATE MUSEUM.}

\section{Family RHYPHIDAE.}

These are known as "false crane flies," differing in the smaller size and broader, spotted wings. They often come into houses, and the larvæ live in water, rotten wood or excrementitious matter. They are of no economic importance.

\section{RHYPHUS Latr.}

R. alternatus Say. Caldwell (Cr); Morris Plains VI, 25, Riverton III, 20, Clementon V, 30 (Jn); Merchantville VI, 26 (Dlie).

R. punctatus Fab. Palisades (Lv): Monmouth County (Sm); Delair X. 5 (Dke); Camden XII, S (Kp); Westville (Jn).

R. fenestralis Scop. Camden VIII, $12(\mathrm{Jn})$.

\section{Family STRATIOMYID王.}

Known as "soldier flies" from their yellow bands and stripes. Usually they are somewhat depressed or even much flattened, especially the abdomen, over which the wings are laid flat and overlapping each other. The mouth parts are developed for lapping only, and the adults are always found among flowers. The antennæ vary in shape, and may be short or of quite moderate length, but always the third joint is compound, and often has an arista.

The larvæ vary greatly in habit, from predatory to feeders upon excrement, living or dead regetable matter, on land or in water; some of them have been even found in salt or alkaline water.

None are of economic importance.

\section{ALLOGNOSTA O. S.}

A. fuscitarsis Say. Caldwell (Cr); Newark VI, 15, Anglesea V, 27 (Jn); New Brunswick (Sm); Trenton V. $21(\mathrm{Hk})$.

A. obscuriventris Loew. Culver's Lake V, 29 (Coll); Westville VI, 15 $(\mathrm{Jn})$; Ocean Co. V $(\mathrm{Sm})$; Clementon $\mathrm{V}, 30$ (Hk); Anglesea V, 30 (W).

\section{ACTINA Meigen. (BERIS Latr.)}

A. viridis Say. New Brunswick, Ocean Co. (Sm); Ashland V, 30, Clementon $\mathrm{V}, 30(\mathrm{Hk})$.

\section{HERMETIA Latr.}

H. illucens Linn. Trenton VII, 7 (HK).

\section{PTECTICUS Loew.}

P. sackeni Will. (testaceus O. S., not Fab.) New Brunswick VIII, 21 (Sm); Dunnfield VII, 15, Riverton VII, 16, Westville VII, 2 (Jn); Brown's Mills VIII, 30, bred from fungus (Dke).

P. trivittatus Say. (similis Will.) Dunnfield VII, 8, Riverton VI, 20, VII, 3 , Westville VIII, 8 . 




\section{GEOSARGUS Bezzi. (SARGUS Fab.)}

G. decorus Say. Caldwell (Cr); Palisades (Lv); Newark VI, 14, Jamesburg V'II, 4 (.In); Trenton V. 26 (Hk); Riverton VI, 15, Merchantville $\mathrm{V}, 26$ (Dke).

G. elegans Loew. Caldwell (Cr).

G. viridis Say. Trenton V, 21 (Hk); Clementon V, 30 .

G. cæruleifrons Johns. Dunnfield VII, 12 (Jn); Riverton VI, 15 (Dke).

G. cuprarius Linn. Orer fifty specimens of this European species were taken along Second River, near Newark VI, 12-14, 1892 (Jn); one specimen, Caldwell VI, 10, 1892 (Cr).

\section{PED!CELLA Bigot. (MACROSARGUS Bigot.)}

P. clavis Will. Newark VI (Wdt).

\section{MICROCHRYSA Loew.}

M. polita Linn. Newark V, Merchantrille VII, 19 (Jn): New Brunswick $(\mathrm{Sm})$.

\section{STRATIOMYIA Geoff.}

S. meigenii Wied. Westrille VII, 5, VIII, 8 , Anglesea V'II, 19.

S. norma Wied. Del. Water Gap VII, 15 (Jn); Caldwell $(\mathrm{Cr})$.

S. discalis Loew. Elizabeth V, 17 (Kp); Ashland Vl, 21 (Hk); Westville VI, 15, Cramer Hill V, 23. Clementon $\mathrm{V}^{\mathrm{V}}, 16$ (Ji).

\section{ODONTOMYIA Meig.}

O. cincta Olir. Palisades VI, 7 (Lv); Avalon VI. 9, Anglesea V, 30, VII, 25, Cape May VI, 14 (Jn).

O. hieroglyphica Oliv. Morris Plains VI, 25.

O. vertebrata Say. Westville VI, 14, Avalon VI, 30, Anglesea V, 30, VII, 19 (Jn); Ashland Y'II, 16 (Hk).

o. virgo Wied. Westville VII, 12, Merchantvilie VI, 28 (Jn); Trenton VII, 7, Clementon VI, 25 ( $\mathrm{Hk})$.

o. microstoma Loew. Atlantic City VII, 15. Anglesea VII, 25, Cape May VI, 22.

O. flavicornis Oliv. Caldwell (Cr); Sonthern New Jersey (Sm).

O. interrupta Oliv. Sandy Hook, Westville IV, 26, Clementon V, 10 (Jn); Ashland $\mathrm{V}, 13$ ( $\mathrm{Hk})$.

o. pubescens Say. Sandy Hook.

\section{EUPARYPHUS Gerst.}

E. tetraspilus Loew. Boonton VI, 14 (GG).

\section{ADOXOMYIA Kertéz. (CLITELLARIA Auct.)}

A. subulata Loew. Riverton VII, S.

47 IN 


\section{NEMOTELUS Geoff.}

N. carbonarius Loew. Avalon VI, 8, Anglesea VII, 4, Cape May VI, 14.

N. crassus Loew. Lenola V, 30 .

\section{OXYCERA Meigen.}

O. maculata Oliv. Merchantville VI, 28, Clementon V, 30, Lenola (Jn); Egg Harbor VII, 10 (Coll).

\section{PACHYGASTER Meigen.}

P. pulcher Loew. Avalon VII, 22.

\section{Family TABANIDA:}

These are moderate or large species, popularly known as "horse-flies," but locally and referring to special types, also as "gad-flies," "deer-flies," "ear-flies," "golden-eyed flies," "strawberry flies," etc. They have short, broad heads, enormous, often gaily colored eyes, flattened abdomen, and short though many-jointed antennæ. The mouth parts consist of a series of sharp, pointed lancets, four in the male, six in the female, inclosed in a soft, fleshy labella or lip. The males live on plant nectar, and do not "bite," but the females attack animals of all kinds and are often a serious annoyance to stock. They frequent woods or the edges of woodland, low meadows or marshy places, and, as Mr. Daecke interestingly shows, the species are often present in very limited areas. They are often troublesome in wood roads, because, with three or four of these flies buzzing about, horses may be driven almost frantic; and so sharp and rigid are the mouth structures that blood appears almost as soon as the insects strike. The species along shore are usually light in color, the eyes green, whence the term "green-heads" that is applied to them. The larger species of "Tabanus" do not often attack man, but the species of "Chrysops" are frequently troublesome in the woods.

In some localities the flies are a serious pest to stock, and in such places much good can be done by collecting the flies. There are also a few animals that are especially liable to attack, and from such the flies can be collected with a small net in such quantities as to materially reduce the supply. As each female fly may lay from 200 to $500 \mathrm{eggs}$, the effect upon the future generations will be decidedly marlied. The attack may be even concentrated on a few gentle animals by treating the others with fish oil soap, to which a little crude carbolic acid has been added.

The larvæ are elongated, somewhat flattened creatures, living in the mud along water courses and in swamps, and they feed upon the organic material found in such places. Clearing and draining will gradually reAuce breeding places as the lands are brought under cultivation.

The present list has been prepared by Mr. V. A. E. Daecke, who has made a special study of the species of this family, and in general, when not otherwise rredited, the records are his, as are also the changes made in nomenclature from the previous edition. 



\section{PANGONIA Latr.}

P. pigra O. S. Dunnfield, Del. Water Gap VII, 12 (Jn).

P. rasa Loew. New Hupe (Hk).

\section{GONIOPS Aldrich.}

G. chrysocoma O. S. Dunnfielı, Del. Water Gap ViI, 11 (Ju).

\section{CHRYSOPS Meigen.}

C. excitans Wlk. Lakeluurst VI, 15 (Ds); Toms River V. 30, Bamber V, VI, 3 (Dlie).

C. celer O. S. Common everywhere, mid-May to early July.

C. carbonarius Wlk. (fugax O. S.) Newark VI, 13, Buena Vista VI, 11, Ateo VI, 4 (Jn); Clementon V. 30 (CG); Lacy V, 27, DaCosta V'I, 15, common (Dke).

C. mitis O. S. Jamesburg V'II, 14 (Hk); Brown's IIills VI, 25 (Dkel.

C. cuclux Whitney. Orange Mts. V (Wdt); Trenton VII, 1 (Coll).

c. niger Macq. Common everywhere, V, 12-Vil, $t$ (Dke).

c. brimleyi Hine. Thronghout the pine barrens V, 21-VII, 4 (Dke).

c. amazon Daecke. Brown's Mills, end r'l, early VII, rare (Dke).

c. nigrobimbo Whitney. Throughont the pine barrens end VI-IX (Dlie).

C. plangens Wied. Passaic VI, 8 (Coll): Newark meadows V'I (Wdt); Staten Island VI, 3 (Ds): Atco VI, 4, Avalon V'I, Cape Nay VI, 14 (Jn); Anglesea V, 28 (Dlie).

C. fallax O. S. Dunnfield VII, 11, Morris Plains VI, 25. Jameslyurg VII, Atco VI, 15. Buena Vista VI, 11 (Jn); Chester VIII. Millburn VII (Coll); Wenonah VI. 22; locally common (Dlie).

C. moechus O. S. From all sections of the State V'I, 2S-YIII. S.

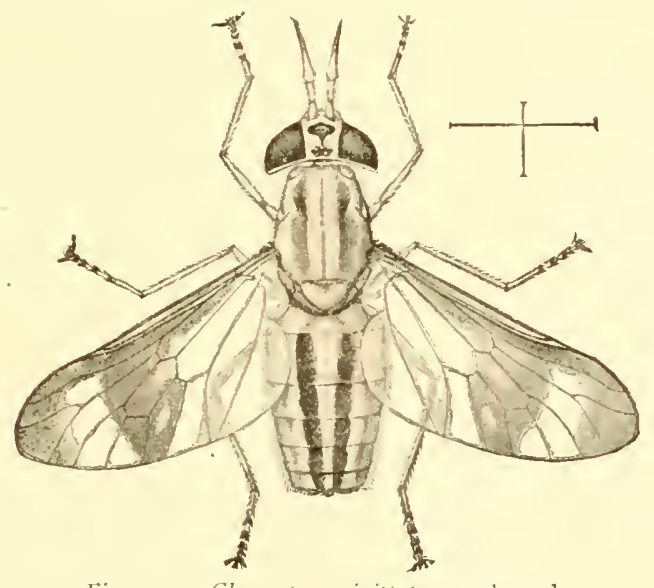

Fig. 303.-Chrysops unizittatus; enlarged.

C. univittatus Macq. Throughont the State VI, 14-VIII, 23; locally a pest along the edges of woods (Dke). 


\section{REPORT OF NEIV JERSEY S'T I'TE MUSEUM.}

C. bistellatus Daecke. Birmingham VII, 8 (Hk); Brown's Mills Dist. end VI to mid VII (Dke).

C. indus O. S. Trenton VII, 5, Ashland VI, 22, Wenonah VI, 23 (Hk); Clementon V, 10-30 (div); Almonesson V, 20 (IV); Brown's Mills V. 27 (Dke).

C. vittatus Wied. From all sections of the State VI, 28-IX, 1.

C. striatus O. S. Delair VIII, 7, rare (Dke).

C. sequax Will. Ashland VII, Clementon IX, 7 (Hk); Wenonah VII, Lucaston IX, \& (Dke).

C. lugens Wied. Trenton VII, 15 (Hk).

var. morosus O. S. Trenton VII (div); Newbold VII, 14 ( ( $\left.^{*}\right) 21$ (q), Bamber VII, 9, Toms River VII, 12 (Dke); Wenonah VI, 23 (Hk); Lake Hopatcong VIII, 6, Lakehurst VIII, 23 (Coll).

C. parvulus Daecke. Jamesburg VII, 4 (Hk); Lakehurst (Ds); Bamber VII, 9, Toms River VII, 12 (Dke).

C. hinei Daecke. Lakehurst IX, 3-16 (Ds); Atlantic Co. VIII, 7 (Coll); Weymouth VIII, 16, Iona VIII, 25 (Dke).

C. obsoletus Wied. Ft. Lee VI, 23, National Park VIII, 13, Wenonah VI, 22 (Dlie); Trenton VII, 11 (Hk); Jamesburg VII, 4, Westville VII, 26. Avalon VII, 22 (Jn); Clementon VII, 23 (CG).

C. delicatulus O. S. Lakehurst VII, 7 (Coll), Brown's Mills VI, 25, Toms River VII, 12, DaCosta VI, 29, Bamber VII, 9 (Dke).

C. callidus O. S. Common everywhere, early $\mathrm{V}$ to end of VII.

C. dimmocki Hine. Iona VI, 2, Anglesea V, 28, Cape May VI, 7 (Dlie).

C. montanus O. S. Morris Plains VI, 24, Merchantville VI, 28 (Jn); Trenton VII, 5, 11 (Hk); Clementon VI, 25-VIII, 8 (div).

C. sackeni Hine. Paterson VI, 7, Trenton VI, 28 (Coll); Ft. Lee VII, 4, Brown's Mills VI, 17, DaCosta VI, 3 (Dlie).

C. frigidus O. S. Dover VI, 23 (Jn).

C. pudicus O. S. Trenton VII, 11 (Hk); Brown's Mills VI, 27-VII, 1, DaCosta VI, 24 (Dke); Atco VI, 18, Anglesea (Jn).

C. cursim Whitney. Jamesburg VII, 4, Clementon VI, 24 (Dke); Lakehurst VI, 16 (Ds); Brown's Mills VII, 1, DaCosta VII, 4 '(Dke).

C. fulvostigma Hine. Lakehurst VII, 27, one specimen (Ds).

C. brunneus Hine. Newark meadows VII (Wdt); Cape May VIII, 9 (Dke).

C. flavidus Wied. Linden VII, 16 (Coll), Trenton VII, 5 (Hk): and from all sections south of the Piedmont Plain VI, 29-VIII, 23.

\section{HAEMATOPOTA MEIg.}

H. punctulata Macq. Jamesburg. VII, 4 (Jn).

TABANUS Linn. (THERIOPLECTUS Zell.)

T. cinctus Fab. Jamesburg VII, 4 (Hk); Lakewood (div); Lakehurst VII, 4 (Coll); Brown's Mills VII, 1 (Dke). 


T. Iasiophthalmus Macr. Common throughout south Jersey, less abundant on the Piedmont Plain and northwardly V, 28-VII, 15 (Dke).

T. trispilus Wied. Throughout the State VI, 2S-VII, 15.

T. epistates O. S. Morris Plains VI, 24 (Jn); Glassboro VI, 18 (CG); Sea Isle City V (Luccareni); Cape May Vl, 7 (Dlie); includes the records under "affinis" Kirby, of last edition.

T. hinei Johns. (politus Johns.) Type locality Nerchantrille VI. 28 (Jn); Jamesburg VII, 4 (div): Malaga VII, 20, Brown's Mills VI, 17, 25 (Dke); Clementon YI, 24 (HIs).

T. recedens Wlk. (catenatus O. S.) Caldwell VI, 15 (Cr); New Bruns. wick IX, 24 (Coll); Jamesburg VII, 4 (Hk); Merchantyille VI, 19 (Kp); Lakewood (Lansing); Brown's IIills VI, 5-21 (Dlie); Atlantic Co. VI, $24(\mathrm{Sm})$.

T. exul O. S. Caldwell (Cr); Orange Mits., Newark VII, 11, New Brunswick VII, 22, Lahaway VII, 17 (Coll); Merchantville VII, 19 (CG).

T. sulcifrons Nacq. Dunnfield VII (Jn); Boonton VI, 19 (GG); Manumuskin VIII, 26 (Dke).

T. astutus O. S. Del. Nater Gap) VII (Jn); Janiesburg YII, 4 (HK).

T. abdominalis Fab. Caldwell (Cr); Elizabeth VII, 30 (Kp).

T. molestus Say. Orange Mts. (Sm).

T. trimaculatus Say. Caldwell (Cr); Orange MIs., New Brunswick VII, Lanáway VII, 1 (Coll); Woodbury VI, 4 (Ḱp).

T. melanocerus Wied. Lakewood (Lansing); Brown's Mills VI, 27, VII, 10 (div); Wenonah VII, 15, Bamber VII, 13, Malaga VII, 27 (Dke).

T. coffeatus O. S. Common south of the Piedmont Plain V, 15-YIII, 8.

T. orion O. S. Caldwell (Cr); Palisades (Love); College Farm (Coll); Atco (Kp).

T. nivosus O. S. Type in Coll. A E S is from New Jersey; Riverton VII, 4.

T. vivax O. S. Dunnfield VII, 11, 15 (Jn).

T. longus O. S. Weymouth VIII, 8 (Dke).

T. gracilis Wied. DaCosta VII, 20, Weymouth VIII, 8 (Dke).

T. pumilus Nacq. From all the faunal regions except the maritime VI, 19-VII, 13, locally common.

T. sparus Whitney. Common south of the Piedmont Plain V, 25-VII, 26.

T. lineola Fab. Throughout the State VI, 6-IX, 6, more or less common locally; less abundant in the north.

T. nigrovittatus Macq. The common green-head of the seashore; abundant from Sandy Hook to Cape May, VI, 20-IX, 2. Extends inland sparingly, and is recorded from New Brunswick VIII, 9 (Coll); Glassboro VIII, 2 (CG).

T. costalis Wied. Throughout the State VII, 4-IX,1.

T. conterminus Wlk. Stone Harbor VII, 5 (Dke); 5-mile beach V'II, 20 $(\mathrm{Hl})$.

T. zonalis Kirby. Greenwood Lake $\mathrm{T}, 30$ (Watson); Prof. Osburn says this is the southernmost record for this species. 


\section{REPOR'T OF NEW JERSEY STATE MUSEUM.}

T. fulvulus Wied. Clementon VII, 11 (Hk); Lakewood (Lansing); Malaga VII, 20 (Dlie).

T. sagax O. S. Boonton VI, 20 (GG); Jamesburg VII, 4 (Hk); Lakewood (Lansing): Brown's Mills VI, 24, VII, 10 (div); Bamber VIII, 11, Lacy VII, 23 (Dke).

T. nigrescens Pal. Beauv. Dunnfield VII, 8, 15 (Jn); Caldwell (Cr); Lahaway VII, 22 (Coll): Brown's Mills VII, 10 (Hk).

T. superjumentarius Whitney. Dunnfield VII, 11 (Jn); Jamesburg VII, 4 (div).

T. stygius Say. Boonton VI, 20 (GG); Caldwell (Cr); New Brunswick VII. 20 (Sm): Jamesburg VII, 4 (Hk); Riverton VII, 14 (Jn); Camden, Merchantville VII, 19 (CG); Manumuskin VI, 21 (Dke).

T. atratus Forst. Throughout the State, more or less common VI \& VII. Our largest "horse fly," blue black in color, with a prninose coating when fresh.

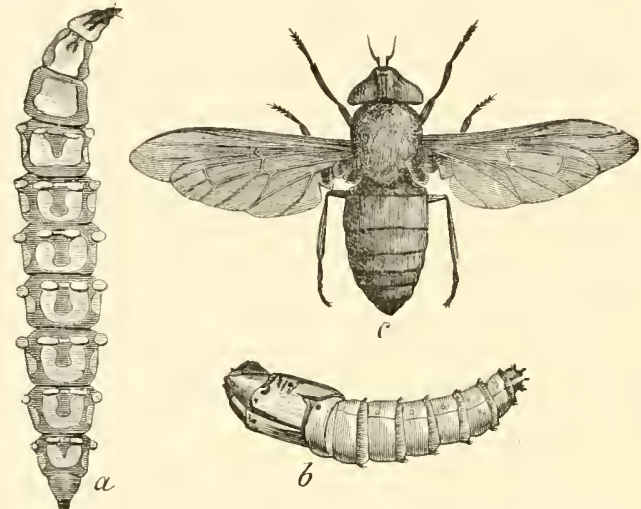

Fig. 304.-Tabanus atratus, black horse fly: $a$, larva;

b. pupa; $c$, adult.

T. americanus Forst. Glassboro VII, 1, VIII, 1 (GG); Lakewood (Lansing); Pt. Pleasant, Atlantic City VIII (Stone); Brown's Mills VIII, 4, DaCosta VII, 20 (Dke).

T. giganteus DeG. Caldwell (Cr); Ft. Lee VIII, 14 (Dke); Palisades (Lv).

T. mexicanus Linn. DaCosta VIII (Bland).

T. reinwardtii Wied. Dunnfield VII, 11 (Jn): Caldwell (Cr); New Brunswick ( $\mathrm{Sm}$ ).

T. typhus Whitney. DaCosta VI, 4 (Dke).

T. bicolor Wied. Orange Mts. VII, 4, Clementon V, 30, Buena Vista VI, 11 (Jn); Collingswood VII, 17 (CG); 2-mile beach VII, 12 (Dke).

$$
\text { Family, LEP'TID Æ. }
$$

Termed "snipe flies" by Prof. Comstock because of the general form of body in many species. The thorax is rather globular, the abdomen 


pointed, the head moderately large, antennæe short, mouth parts prolonged into a beak projecting downward and backward, legs rather long and slender. Some of the species are densely hairy, with contrasting golden yellow and black or brown markings. They are predatory in habit, but rather sluggish in motion. The larve are also predatory, and live under widely-varying conditions.

\section{XYLOPHAGUS Meigen.}

X. persequus Walk. Caldwell (Cr): Clementon IV, 22 (Dlie).

X. Iugens Loew. Caldwell (Cr): Palisades $\mathrm{H}$, under chestnut bark (Lv); Riverton IV, 17 (Jn); Woodbury IV, 29 (Kp).

X. abdominalis Loew. Riverton: the larve and pupæ were found beneath the barli of a read pine III, 20; imagroes emerged IV, 5 and 8 (Jn) ; Grenloch V, $6\left(\mathrm{~W}^{*}\right)$.

\section{XYLOMYIA Rond.}

X. pallipes Say. New Brunswick VI, 10, Lahaway VII, 6 (Sm); National Park VI, 3, Westville VI, 30 (Dlie).

X. tenthredinoides V. d. W. Ft. Lee VI, 23 (Dke); Wenonah VI, 23 (Hk).

DIALYSIS Walker.

D. rufithorax Say. Trenton VII, 3 (Hk); Westville VI, 6. Melchantville VI, 28.

D. elongata Say. Dunnfield VII, 12, Jamesburg VII, 4.

\section{LEPTIS Fab.}

L. punctipennis Say. Dover VI, 17, Newark VI, 16, Westville VI, 6, Clementon $\mathrm{V}, 30$.

L. plumbea Say. New Brunswick (Sm).

L. mystacea Macq. Palisades V, 24 (Lv); Dover VI, 18, Woodbury IV, 30, Clementon V. 30 (Jn); New Brunswick (Sm).

L. hirta Loew. Dunnfield, Del. Water Gap VII, 15.

L. ochracea Loew. Dunnfield, Del. Water Gap VII, 8-15.

L. scapularis Loew. "New Jersey" (Bt).

\section{CHRYSOPILA Macq.}

C. ornata Say. Dover VI, 18, Newark VI, 16 (Jn); Palisades V, 30 (Lv); Trenton VII, 9 (Coll).

C. thoracica Fab. Dover VI, 17, Newark VI, 13 (Jn); Orange MIs., Anglesea VII, $25(\mathrm{Sm})$.

C. fasciata Say. Dumnfield VII, 8, 14, Newark VI, 15, Westville VII, 2 (Jn); Trenton VII, 7( $\mathrm{Hk})$.

C. quadrata Say. Dunnfield VII, 8, 15, Ft. Lee; Atco VII, 12, Riverton VI, 15, Anglesea VI, 11. 


\section{REPORT OF NEIV JERSEY STATE MUSEUM.}

C. propinqua Walk. Mullica Hill, Clementon V, 30, Anglesea VII, 25.

C. basilaris Say. Ft. Lee VII, 4 (Dke); Riverton VII, 3, Westville VIII, 18.

C. rotundipennis Say. Buena Vista VI (Li); Riverton VI, 19, VII, 3 (Jn);

Egg Harbor VII, 10 (Coll).

\section{SYMPHOROMYIA Fraun.}

S. cinerea Johns. Long Branch VI, 9-12.

\section{Family CYRTID瓜.}

Called "small-headed flies" because of the unusually small head com. pared with the large hump-backed thorax and inflated abdomen. They are the "Acroceridæ" of previous list, are rare, the larvæ are parasitic upon spiders or their egg sacs, and they are of no economic importance.

\section{ONCODES Latr.}

O. costatus Loew. "New Jersey," no data.

O. pallidipennis Loew. Trenton VI, 3 (Hk); Anglesea VI, 20 (Sm).

O. incultus O. S. Boonton VI, 16 (GG); Collingswood VI, 11 (Jn).

\section{OPSEBIUS Costa.}

O. pterodontinus O. S. Lakehurst VIII, 18 (Coll); parasitic on "Agalena nævia."

\section{ACROCERA Meigen.}

A. fasciata Wied. Philadelphia, bred from "Lycosa stonei," a spider which also occurs in New Jersey.

\section{Family BOMBYLIID王.}

These are the "bee-flies." which derive their common name from the fact that they are more ol less covered with dense, diverging whitish or yellow hair, giving them a close resemblance to certain bees. Many occur. hovering over bare places in early spring, others are found on flowers, often poised in mid-air between or over them. One series resembles the bumble-bees and has a long pointed proboscis; the other is more slender, the abłomen tending to become flattened, with a short proboscis anc much less contrasting colors.

The larvæ are parasitic or partly predatory. Some are true parasites in lepidopterous larvæ; others feed on the egg-pods of grasshoppers while yet others feed in nests of bees, destroying first the bee egg or larva and then feeding upon the food stored for it.

They are never harmful to growing vegetation, hence may be classed as, on the whole, beneficial. 




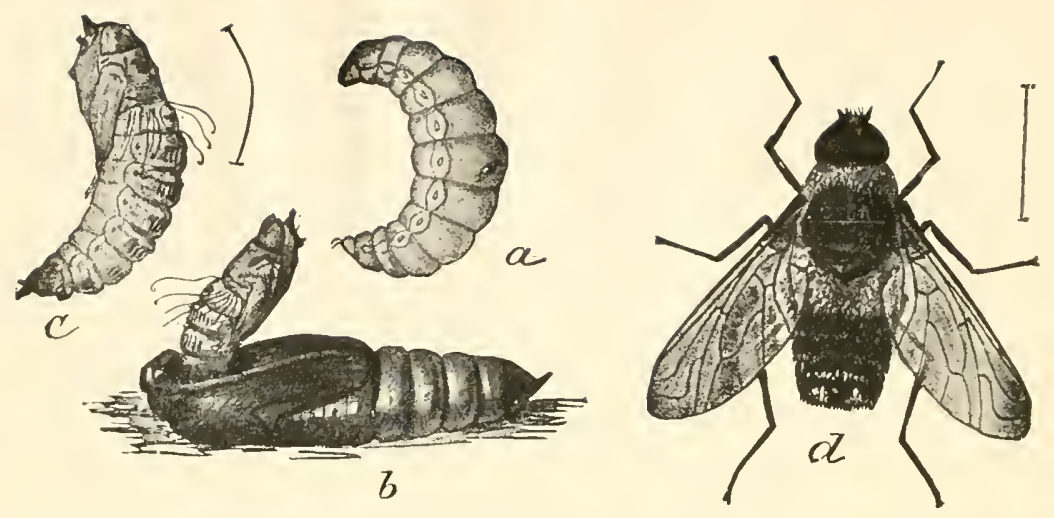

Fig. 305 .

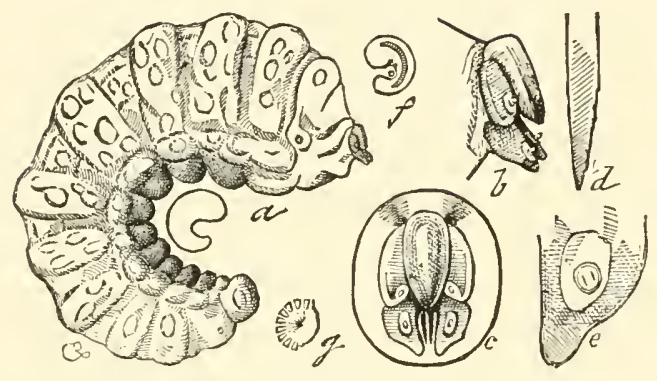

Fig. 307 .
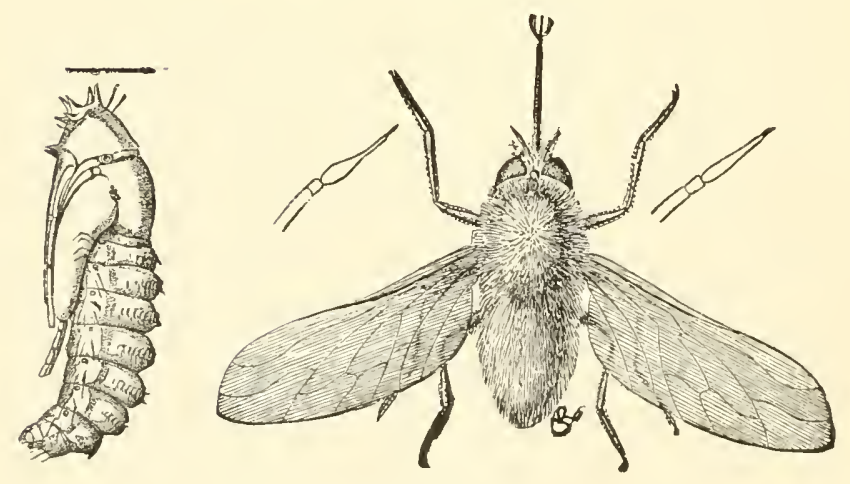

Fig. 306.

Fig. 305.-Anthrar hippomclas: a, larva; b, fly pupa projecting from cut-worm pupa; $c$, pupa; $d$, adult: all cnlarged.

Fig. 306.- Bee-fly, Systachus orcas, parasitic on grasshopper cgg-pods, pupa and adult,

Fig. 307.-Larva of Systochus oreas enlarged and details of structure. 


\section{SPOGOSTYLUM Macq.}

S. analis Say. Del. Water Gap VII, 10, Sandy Hook, Anglesea IX, 4 (Jn); Malaga IX, 5 (Hk); Lakewood VIII (Lansing); Atco IX, 1 (Kp); Clementon VIII, 9, Sea Isle VII, 22 (Jn).

S. albofasciatum Macq. Westrille VIII, 21, Atco VII, 9, Buena Vista VI, $11(\mathrm{Jn})$; Clementon VI, VIII (div); Pemberton IX, 1 (Hk); Iona VI, 2 (Dke).

S. pauper Loew. Del. Watel Gap VII, 10. Westrille V'III, 14-23 (Jn); Clementon VI, VIII (dir); Pemberton V'II, S (Hk); Atco IX, 1 (Kp); Anglesea IX, S (Dlie).

S. limatula Say. Riverton IX, 5 .

S. argyropyga Wied. Dunnfield VII, 11, 15, Riverton VII, 4 (Jn); Trenton VII, 9 ( $\mathrm{Hk})$.

S. œdipus Fab. Del. Water Gap VII, 12, Westrille V, 18, VI. 27, VIII, 23 (Jn); Chester (Dku); Caldwell (Cr); Lahaway VII, 1 (Coll).

S. simson Fab. Boonton VIII, 22, IX, 5 (GG); Caldwell (Cr); Sandy Hook (Bt); Trenton IX, 2, Pemberton IX, 1 (Hk); Westville VIII, 23, Clementon VIII, 7, Atco VII, $S$ (Jn).

S. cephus Fab. Alpine T'II, 12 (Engelhardt).

\section{EXOPROSOPA Macq.}

E. fascipennis Say. Palisades VII, 26 (Lv); Caldwell (Cl); Westville VIII, 14-23 (Jn); Lakewood VIII (Lansing); Pemberton IX, 1, Lucas ton $1 \mathrm{X}, 9(\mathrm{Hl})$.

E. emarginata Macq. Laliewood VIII (Lansing); Manumuslin VI, 23, VII, 5 (Dlie).

E. fasciata Nacq. Boonton VIII, 19 (GG); Caldwell (Cr); Riverton IX. 9. Nalaga IX, 15 (Hk); Westville VIII, 23, IX, 10 (Jn); Lakewood (Lansing); Manumitskin VIII, 26 (Dke).

\section{ANTHRAX Scop.}

A. lateralis Say. Del. Water Gap VII, 11. Jamesburg VII, 4, Westville VIII, 23, Clementon V, 30, VIII, 9, Anglesea VIII, 15 (Jn); Trenton VII, 9 ( $\mathrm{Hk})$.

var. gracilis Macq. Westville VI, 15 (Jn).

var. arenicola Johns. Riverton $\mathrm{IV}^{\mathrm{T}}, 30$, Clementon $\mathrm{V}, 16$ (Jn).

A. alternata Say. Caldwell (Cr); Sandy Hook (Sm); Westville VI, 15 VIII, $23(\mathrm{Jn})$; Clementon IX, 5, Brown's Mills VII, 10 (Hk); Manumuskin VI, 24-VII, 5 (Dke).

A. hypomelas Macq. Chester (Dkn); Orange Mts. VIl, 4, Shiloh IX, 1, Westville IX, 10; Riverton IX, 2 (GG).

A. fulvohirta Wied. Caldwell (Cr); Riverton VII, 2, IX, 22 (div); Westville VIII, 28 , Clementon VII, $26(\mathrm{Jn})$; Malaga VIII, IX (div): DaCosta VII, 20 (Dke). 


\section{REPORT OF NEIV JERSEY STATE MUSEUM.}

A. tegminipennis Say. Sandy Hook VIII (Bt).

A. ceyx Loew. Clementon VIII, 6-IX, 7 (div); Lakewood (Lansing); Atco VIII, IX, \& (GG); Manumuskin VIII, 26-IX, 3 (Dke).

A. sinuosa Wierl. Caldwell (Cr); Jamesburg VII, 4, Riverton VI, VII, DaCosta VII, 30, Buena Vista VI, 11 (Jn); Pemberton VII, 8, Brown's Mills VII, 10 ( $\mathrm{Hk}$ ).

A. lepidota O. S. Iona VI, 16 (Dke).

A. faunus Fab. Clementon $\mathrm{X}, 1$ ( $\mathrm{Hk}$.

\section{BOMBYLIUS Linn.}

B. major Linn. Palisades IV, 8 (Lv); Newark V, Westville IV, 9, Clementon IV, 15 (Jn)

B. pygmaeus Fab. Caldwell (Cr); Orange Mts., Jamesburg V, 4 (Sm); South Amboy V, 5 (Kp); Glassboro V, 19 (Hk); Manumuslin IV, 28 (Dke).

B. pulchellus Loew. South Amboy V, 5 (Kp); Jamesburg V, Westville V, 6 (Jn); Glassboro V, 19 (Hk); Hainesport V, 7 (Dke).

B. subvarius Johns. (lancifer Johns., not O. S.) Morris Plains VI, 25.

B. fulvibasis Macq. (atriceps Loew.) Clementon V, 10, 30 (Jn); Manu. muskin V, 12 (Dke).

B. varius Fab. Trenton VII, 3 (Hk); Westville VI, 15, VII, 2, Riverton VI, 17, VII, 3 (Jn); Buena Vista VI, 8 (Li); Clementon VI, 17 (GG).

B. incanus Johns. (philadelphicus Macq.) Clementon V', 30, VI, 25, Atco VI, 1S, Jamesburg VII, 4 (Jn); Albion VI, 1 (C); Brown's Mills Jc. VI, 22, Iona VI, 2 (Dke).

B. fraudulentus Johns. Dover VI, 25, Morris Plains VI, 24, Orange Mts. VII, 4, Jamesburg VII, 4 (Jn); Iona VI, 2 (Dke).

B. mexicanus Wied. Clementon V, 30, Riverton VI, 9-16 (Jn); Iona VI, $\$$, Brown's Mills VII, 4 (Dke).

\section{SYSTCECHUS LOEW.}

S. vulgaris Loew. Pemberton IX, 1 (Hk); DaCosta VII, 19, Clementon VIII, 7-9 (Jn); Lakewood, Burlington Co. (Sm) ; Iona V1II, 25, Weymouth VIII, 16, Brown's Mils VII, 10 (Dke).

\section{ONCODOCERA MaCS.}

O. leucoprocta Wied. Clementon V, 30, VI, 25, Atco VI, 18 (Jn); Toms River (Edwards); Bamber VII, 13, Manumuslin VII, 5, Iona VII, 13 (Dlie).

\section{PHTHIRIA Meig.}

P. sulphurea Loew. Lakewood, Atco VI, 13, 18, Riverton IX, 11 (Jn); Lucaston VIII, 11, Hammonton IX, 6 (Dke).

P. coquilletti Johns. Jamesburg VII, 4, Riverton VII, 4-6. 




\section{LEPIDOPHORA Westwood.}

L. ægeriiformis Westw. Caldwell (Cr); DaCosta VII, 28, Brown's Mills IX, 15 (Dke).

\section{SPARNOPOLIUS LOEW.}

S. fulvus Wied. Chester (Dlin); Riverton IX, 11, Westville VIII, 28 (Jn); Clementon IX, 5 (Hk); Atco IX, 11 (Nell); Belleplain IX, S, Lucaston IX, 12 (Dlie).

\section{ECLIMUS Loew.}

E. niger Macq. Brown's Mills VI, 15, V1, 23 (Dke).

\section{METACOSMUS Coo.}

M. mancipennis Coq. Pemberton VII, 11 (CG).

\section{SYSTROPUS Wied.}

S. macer Loew. Caldwell (Cr); Lakewood (Lansing); Clementon VIII, 9 (Jn); Atco IX, 1 (Kp); lucaston V1l, 27 (GG): Anglesea IX, 8 (Dke).

\section{GERON Meig.}

G. senilis Fab. Jamesburg VII, 4, Atco V11, 12, Clementon VI, 25, VIII, 7 (Jn); Hammonton IX, 6 (Dlie).

G. subauratus Loew. Dunnfield VII, S, Westville VI, 27 (J11); DaCosta V'II, 19, Brown's Mills VI, 24-VII, 21 (Dlie).

G. calva Loew. Dunnfield, Del. Water Gap VII, 11-12.

G. capax Coq. Riverton IS, 30 (Jn); Manumuslin IV, 28 (Dke).

TOXOPHORA Meigen.

T. amphitea Walk. Lakehurst VII, 7 (Coll); Buena Vista VI, 11, Atco VI, 18, DaCosta VII, 30 (Jn): Hammonton VilI, 21 Bamber VII, 13, VIII, 11, Manumuskin VI, 23 (Dlie).

\section{Family THEREVID EE.}

Called "stiletto flies" by Comstock, because of their slender, pointed abdomen. They resemble the robber flies, but have longer legs and are more slightly built. They are also predatory, but the lips are broad and fleshy, and they are not nearly so active as the "Asilidæ."

The larvæ are long and slender, the segments constricted so that they seem doubled in number, and they live in mold, fungi, rotten wood and vegetable decay generally, feeding sometimes upon the material among which they are found, sometimes upon such other insects as come in their way.

They can scarcely be said to be beneficial, for the prey of the adult does not usually consist of insects that are harmful to the farmer. 


\section{$7+8$ REPORT OF NEW JERSEY STATE MUSEUM.}

\section{TABUDA Walker.}

T. fulvipes Walk. Riverton IV, 17, 30, Westville IV, 16, Clementon IV, 15, V, 5 (Jn); Lahaway IV, 20 (Sm); Manumuskin IV, 24-V, 5 (Dke).

\section{PSILOCEPHALA Zett.}

P. hæmorrhoidalis Macq. Newark VI, 16, Jamesburg VII, 4, Westville, VIII, 13, Shiloh IX, 1, Avalon VI, 9, Cape May VI, 14 (Jn); Pemberton VII, 8, IX, 1 ( $\mathrm{Hk})$.

P. morata Coq. Avalon VI, 8, Cape May VI, 14.

P. aldrichii Coq. Jamesuurg VII, 4, Riverton VI, 15, Weymouth VIII, 16 (Dlie); Westville VII, 12, Stone Harbor VIII, 3.

P. rufiventris Loew. Clementon V, 30, Pleasantville VI, 13 (Lt); Westville VII, 2, Atlantic City VIII, Avalon VI, 9, Anglesea VII, 16.

P. scutellaris Loew. Dunnfield VII, 8,12 , Jamesburg VII, 4.

P. pictipennis Wied. Jamesburg VII, 4 (div); Riverton VII, 3, Atco VI, 18, VII, 9 (Jn); Pemberton VII. 8. Clementon V, 30 (Hk).

\section{THEREVA Latr.}

T. senex Wik. Dunnfield VII, 15 (Ju); Boonton VIII, 23 (GG); Caldwell (Cr); Trenton VIII, 11 ( $\mathrm{Hk})$.

T. albifrons Say. Riverton V, 14, Clementon V, 6.

T. sp. Toms River V, 30 (Dke).

\section{Family SCENOPINIDE.}

The "window-flies": small, slight, blue flies, somewhat flattened, and with yellow or red legs. The larvæ are slender and worm-like often found under carpets, where they feed on "moths" and other carpet pests.

\section{SCENOPINUS Latr.}

S. fenestralis Linn. Caldwell (Cr); New Brunswick (Sm); Riverton, Atco VII, 21 (Jn); Glassboro VII, 5 (CG); DaCosta VII, 20 (Dke); Ashland $\mathrm{V}$, VI (Hk).

s. glabrifrons Meig. New Jersey (Jn).

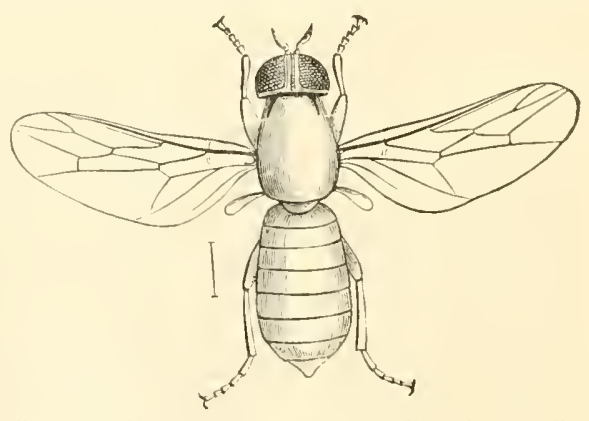

Fig. 308.-The window fly, Scenopinus fenestralis: enlarged. 



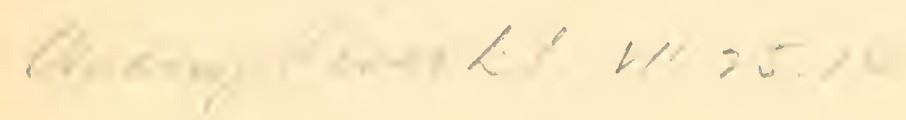




\section{Family MYDAIDA:}

The "Midas flies," resemble the "Asilida" in form and are, like them, predatory. They are much larger, however, with contrasting black and orange colors, the antennæ being long and clubbed at tip. They are practically unimportant.

\section{MYDAS Fab.}

M. clavatus Drury. Ft. Lee (Bt); Caldwell (Cr); Riverton VII, 3, DaCosta VII, 30, Anglesea Vil. 19 (Jn); Brown's Mills VII, 10 (Hk); Manumuskin VI, 22 (Dke).

M. chrysostoma O. S. ( $q$ fulvifrons Illiger) Stone Harbor VII, 3 (Dke); Avalon VII, 29, Anglesea VII, 19 (Jn).

\section{I'amily ASILIDA:}

Head prominent, very hairy, with short, several-jointed antennæ and a short, stout proboscis formed for piercing. The body is robust, hairy. the abdomen long. slender, cylindrical, tapering very gradually to the tip. The wings are long and narrow, the legs moderately long and very powerful, densely clothed with spines, while the tips of the tarsi are supplied with unusually long, stout claws. The insects are called "robber-flies" from their habit of pouncing upon, piereing and sucking the juices of other insects in mid-air while holding them in the grasp of their nowerful legs. Some of the species are brightly colored, but most of them are of a sober gray with blackish mottlings. These robber-flies. though predatory, can scarcely be considered of much real value to the farmer, because they take anything that comes along, useful or otherwise, and are just as reidy to destroy bees as some harmful species.

The larvæ are also carnivorous so far as known, and live in the ground or in decaying wood.

\section{LEPTOGASTER Meigen.}

L. badius Loew. Dunnfield VII, \&, Jamesburg VII, 4, Riverton VII, 30.

L. flavipes Loew. Dunbfield VII, 15, Newark VI, 16 (Jn); Trenton VII, $i(\mathrm{Hk})$.

L. testaceus Loew. Caldwell (Cr); Westville (Jn).

L. incisularis Loew. Delair VIII, 7 (Dlie), Riverton VII, 30, Atco.

L. annulatus Say. (histrio Wied.) Princeton VII, 21 (Jn); Trenton VII, 7 (Hk).

L. pictipes Loew. Dunnfield VII, 12, Clementon V, 30, Atco VI, 18 (Jn); Belleplain IX, \& (Dke).

L. eudicranus Loew. Pemberton VII, 11 ( $\mathrm{Hk})$.

L. favillaceus Loew. Newark IV, 14. 


\section{REPORT OF NEW JERSEY STATE MUSEUM.}

L. varipes Loew. Pemberton VII, 11 (Hk); Clementon VIII, 30 (Hk); Dacosta VII, 4, Banıber VII, 13 (Dke).

L. carolinensis Schimer (virgatus Coq.) Trenton VII, 7 (HK).

\section{LAPHYSTIA LOEW.}

L. sexfasciata Say. Avalon VII, 29, VIII 2 (Jn); Stone Harbor VII, 5, Cape May VII, 15̄ (Dke).

\section{CERATURGUS Wied.}

C. aurulentus Fab. Chester (Coll); Trenton VII, 7 (Hk); Westville VIII, $21(\mathrm{Jn})$.

C. cruciatus Say. Dunnfield VII, 8 (Jn); Caldwell (Cr); Dover VII, 16 (CoII); Great Notch VII, 10 (Dke); 'Trenton VII, 11.

\section{DIOCTRIA Meigen.}

D. albius Walk. Dunnfield VII, 14, Newark.

\section{CYRTOPOGON LOEW.}

C. chrysopogon Loew. Clementon V, 16.

c. marginalis Loew. Clementon $\mathrm{V}, 10$ (CG); Manumuskin V, 10 (Dke).

\section{LASIOPOGON LOEW. (DAULOPOGON Loew.)}

L. opaculus Loew. New Jersey (A E S) ; Riverton V. 3, Clementon V, 6 (CG).

L. terricola Johns, Riverton V, 29, Clementon V, 9, Wenonah V, 14 (Jn); Hainesport $V, 7$ (Dlie).

L. tetragrammus Loew. Clementon Y, 9, Albion V, 16 (Dlie).

\section{HOLCOCEPHALA Jænn.}

H. abdominalis Say. Dunnfield VII, 9, Princeton VII, 21 (Jn); Trenton VII, 11 (HK); Cumberland Co. IX, 1 (Sm).

H. calva Loew. Princeton VII, 21 (Jn); Trenton VIII, 11 (Hk); Cumberland Co. IX, 1 (Sm).

\section{HOLOPOGON LOeW.}

H. guttula Wied. Dunnfield VII, 9, Newark VI, 14, Jamesburg VII, 4 (Jn); Clementon V, 30, VI, 25 (div); Brown's Mills VII, 10 (CG); Manumuskin VI, 23 (Dke).

\section{STICHOPOGON LOEW.}

S. argenteus Say. High Point VIII, 5 (HK); Sandy Hook VIII, Anglesea VII, 22, Avalon VII, 29, VIII, 2 (Jn).

S. trifasciatus Say. Caldwell (Cr); Sandy Hook, Jamesburg VII, 4, Westville VII, 12, Cumberland Co. IX (Jn); Lahaway IX, 26 (Sm); Pemberton IX, 1, Clementon VIII, 15, 5-mile beach VIII, 5 (Hk).

\section{DEROMYIA Philippi.}

D. discolor Loew. Caldwell (Cr); Merchantville VII, 19 (Kp); Glassboro VIII (CG). 


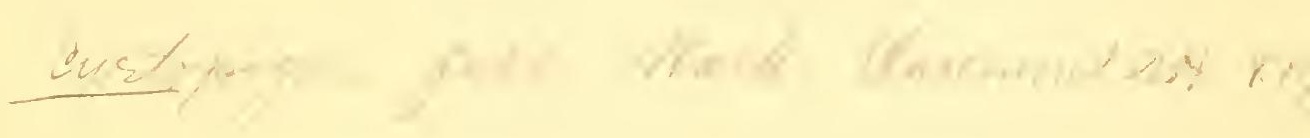



D. umbrina Loew. Dunnfield, Del. Water Gap VII, 14.

D. winthemi Wied. Morristown VII, 18, Lakewood, Atco V'II, 12 (Jn); Atlantic Highlands VII, 11 (Lv); Glassboro VIII, 1 (CG); Lucaston 1X, 9, Malaga IX, $15(\mathrm{Hk})$.

\section{TARACTICUS LOEW.}

T. octopunctatus Say. Dunnfield V'lI, 11 (Jn); Trenton VII, 5 (Hk); Clementon VI, 25 (CG); Buena Vista VII, 10 (Li).

\section{NICOCLES Jænn.}

N. pictus Loew. Clementon IV, 15.

N. politus Say. Riverton IX, 11, Anglesea 1X, + (Jn); Clementon IX, 5, $\mathrm{X}, 4$ (Hk); Manumuskin IX, $\mathbf{X}$ (Dke).

\section{CEROTAINIA Schiner.}

C. macrocera Say. Newark VII, 14, Princeton VII, 21 (Jn); Trenton VII, $\delta$ (Hk); Newbold VII, 14 (Dlie).

\section{ATOMOSIA Macq.}

A. puella Wied. Caldwell (Cr); Trenton VII, 5 (Hili); Merchantville Vrl, 29, VII, $19(\mathrm{Jn})$.

A. sayii Johns. New Brunswick VIlI, 21 (Sm); Laurel Springs VII, 12.

A. glabrata Say. Springfield VIIl, 23 (Jn); Trenton VII, 5 (Hk).

\section{POGONOSOMA Rondani.}

P. melanoptera Wied. Atlantic Co. XI, 24 (Sm); Malaga VIII, 4 (CG).

DASYLECHIA Will. (HYPERECHIA Schiner.)

D. atrox Will. New Brunswick VIII, 28( Sm).

\section{LAMPRIA Macq.}

L. bicolor Wied. DunnfieId VII, 15 (Jn): Cal(Iwell (Cr).

\section{DASYLLIS Loew.}

D. flavicollis Say. Dunnfield VII, 12, Morris Plains V'I, 17, 25, Newark VI, 4, Jamesburg VII, 4, Atco VI, 18 (Jn); Brown's Mills VI, 22 (Dke).

D. posticata Say. Dunnfield VII, 11, Jamesburg V1I, 4, Westrille V, 17, Atco YI, 4 (Jn); LaureI Springs $V$, 23, bred from decaying pine stump, Manumustin VI, 24 (Dlie).

D. thoracica Fab. Dunnfield VII, 11, Morris Plains VI, 25, Newark VI, 14, Atco VI, 4 (Jn): Trenton VII, 3 (Hk); Westville VI. 6 (CG); Prospertown VI, $T(\mathrm{Sm})$.

D. grossa Fab. Dunnfield VII, 11 (Jn); Caldwell (Cr); Jamesburg VII, 4 (CöIl); Lakiewood (Lansing); Glassboro (CG); Brown’s Mills VII, 10 ( $\mathrm{Hk}$ ). 


\section{REPOR'T OF NEIT JERSEY S'TATE MUSEUM.}

D. melanopogon Wied. (affinis Macq.) Riverton $\mathrm{X}, 20(\mathrm{Jn})$; Malaga $\mathrm{X}$, 15 (CG) ; Hammonton IX, 6, Brown's Mills IX, 16, Mannmuskin X, 21 (Dlie).

D. analis Macq. (lata Macq.) Atco VI, 18 (Jn).

\section{LAPHRIA Meig.}

L. canis Will. Ft. Lee VI (Lv); Dover VI, 18, Newark VI, 12, Merchantville VI, 25, Clementon V, 30 (Jn); Trenton VII, 11 (Hk); Delair VIII, 14 (Dlie).

L. sericea Will. Dunnfield, Del. Water Gap VII, S-15.

L. æratus Wlk. New Jersey (Jn).

\section{OMMATIUS IIIiger.}

O. marginellus Fab. (tibialis Say.) Dunnfield VII, 15, Morris Plains VI, 24, Vestville VII, 5, Shiloh IX, 1, Avalon VII, 23 (Jn); Trenton VII, 11 (Hk); DaCosta VII, 28 (Dke).

\section{PROCTACANTHUS Macq.}

P. philadelphicus Macq. Caldwell (Cr); Lahaway IX, 26 (Sm); Riverton VII, 31, VIII, 21, Westville VIII, 28, IX, 13 (Jn); Clementon VIII, 15, Malaga IX, 15 (Hk); Manumslin VI, 22 (Dke).

P. brevipennis Wied. Clementon VI, 6, VII, 4 (div); Lahaway VIII, 3 $(\mathrm{Sm})$; Atco VII, 12, Anglesea VI, 25, VII, 12 (Jn); Manumuskin VI, 22 (Dlie).

P. rufus Will. Dunnfield VII, 12, Jamesburg VII, 4, Merchantville VI, 26, Anglesea VII, 19 (Jn); Clementon VII, 9 (Hk); DaCosta VII, 28 (Dke); Avalon VII, 5 (CG).

\section{ERAX Macq.}

E. æstuans Linn. (bastardi Macq.) Dunnfield VII, 14, Orange MIt. VII, 4, Jamesburg VII, 4, Riverton V, 29 (Jn); Trenton VII, 11 (Hk); Dacosta VII, 28 (Dke).

E. albibarbis Macq. (cinerascens Bell.) Jamesburg VII, 4, Westville VIII, 16, Anglesea VII, 9, VIII, 24 (Jn); Pemberton VII, \& (Hk); Atco VI, 21 (CG); DaCosta VII, 16, Iona VI, 2 (Dlie).

E. rufibarbis Macq. (æstuans Auct.) Chester (Dn); Malaga IX, 15; Shiloh IX, 1 (Jn); Glassboro, Avalon VIII, 29 (CG); DaCosta VII, 28 (Dke).

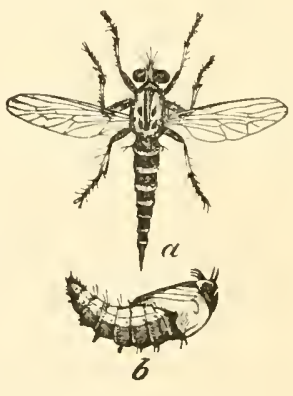

Fig. 309.- Erar astuans and its pupa.

\section{MALLOPHORA Macq.}

M. clausicella Macq. Pemberton IX, 1 (Hk); Atco VII, 9, DaCosta VII, 30 (Jn); Clementon VII, 26 (CG); Avon IX, 14, Lucaston IX, 2 (Dke). 


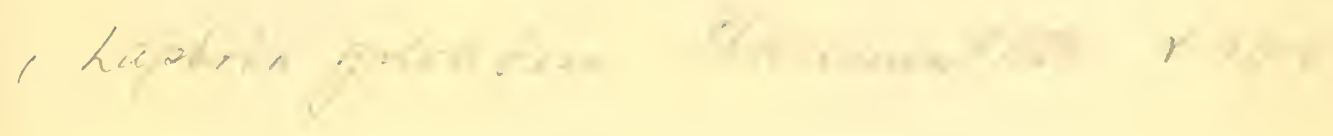

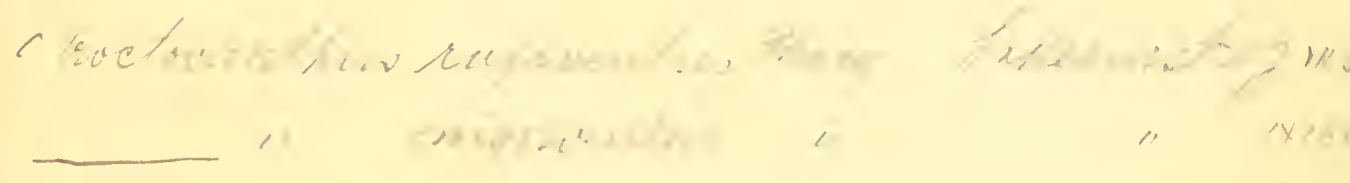

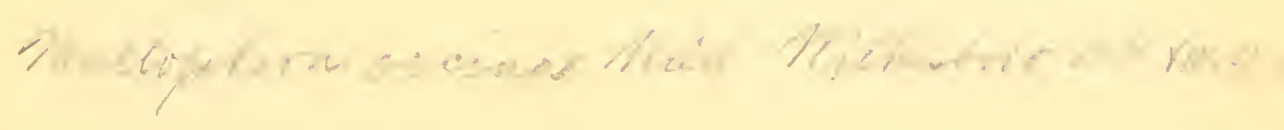




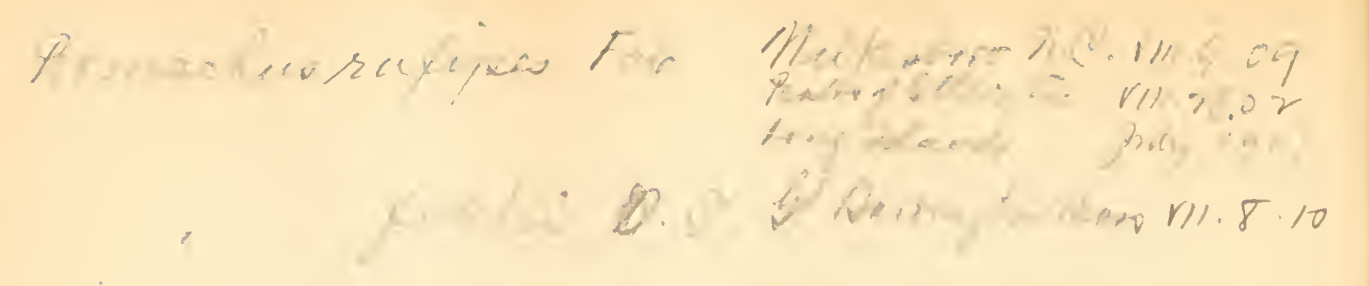


PROMACHUS LOEW.

P. bastardi Macq. New Jersey (A E S).

\section{ASILUS Linné.}

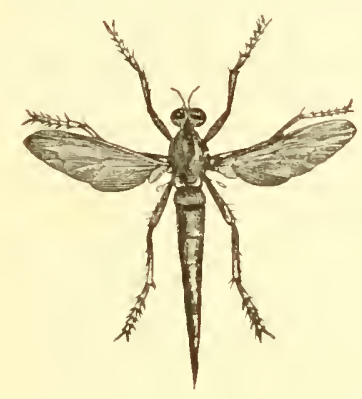

liig. 3 ro.

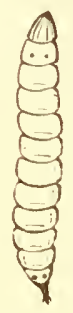

Fig. 31 .

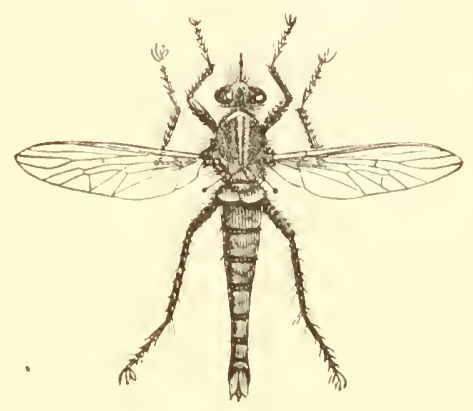

Fig. 312 .

lig. 310 - Silky robber fly, Asilus sericens.

Fig. 312.- Isilid larva.

Fig. 312. Missouri bee-killer: 1silus missouriensis.

A. sericeus Say. Ft. Lee VII, 4 (Dke): Caldwell (Cr); Orange Mts. VII, 4, Merchantrille VI, 26, Atco VI, 19 (Jn); Trenton VII, 3 (Hk).

A. cacopilogus Hine. Atlantic City VII, 15 (Jn); Anglesea (Hk).

A. fuscatus Hine. Newark VI, 1:), Jamesburg VII, 4 (Hk); Riverton VI, VII (div).

A. lecythus Walk. Dover VI, 1S, Morris Plains VI, 25, Newarle VI, 14.

A. orphne Walk. (distinctus Will.) Del. Water Gal VII, 8, Dover VI. 17 (Jn); Roonton VT, S (GG).

A. flavofemoratus Hine. (flavipes Will.) Dover V1. 18, Newark VI, 14, Jamesburg VII, 4, Fiverton V. 30 (Jn): Trenton V, 25 (Hk).

A. atiricomus Hine. Iona (Dlie); Malaga IX. 15 (CG).

A. notatus Wierl. Del. Water Gap VII, 15, Newark VI, 14, Clementon V, 30, Anglesea VI. 11 (Jn); Ft. Lee VII, 4 (Dke).

A. novæ-scotize Macq. Del. Water Gap VII, 14, Orange Mts., Riverton VII, 31, Anglesea IX, 3 (Jn); Manumuskin IX, 15 (Dke).

A. paropus Walk. Nerchantville VI, 28.

A. sadyates Walk Atco VIII, 9.

A. snowii Hine. (annulatus Will.) New Jersey (Hine); Trenton V, 25 ( $\mathrm{Hli})$.

A. erythrocnemius Hine. New Jersey (Hine).

A. maneei Hine. Malaga VIII, 4 (CG).

The subgeneric terms for the species of this genus have been omitted, for convenience. 


\section{REPORT OF NEW JERSEY STATE MUSEUM.}

\section{Family DOLICHOPODIDA:}

Small, usually shining green, sometimes black or yellow flies, with short antennæ, plump body and comparatively long legs, which are often contrasting yellow or brown. The tarsi or feet are unusually long, whence they are called "long-footed flies," and in the male the anterior pair are often flattened or otherwise modified. In the same sex the abdomen is frequently furnished with curiously complex claspers, which are bent down beneath the body. In the female there is usually a pointed, flat ovipositor. They are predatory in habit, feeding chiefly upon smaller flies. The larvæ are long, slender, cylindrical and feed on decaying vegetation.

\section{PSILOPODINUS Bigot. (PSILOPUS Meigen.)}

P. inermis Loew. Shariz River VII, 12, Buena Vista VI, 11, Atlantic City VIII, 11, Avalon VI, 30.

P. cauciatus Wied. Great Notch IX, 8 (GG); Merchantville VI, 28, Cape May VI, 14.

P. scobinator Loew. Westville V, 5, Atco VII, 9, Clementon VIII, 6.

P. scaber Loew. Caldwell (Cr); Shark River VII, 12.

P. patibulatus Say. Passaic VI, 8 (Coll); Jamesburg VII, 4, Westville VII, 26, Anglesea VII, 19.

P. sipho Say. Caldwell (Cr); Merchantville VI, 28, Mullica Hill V, 30 (Jn); Glassboro VII, 20 (CG).

\section{AGONOSOMA Guérin. (GRAMPTOPSILOPUS Aldrich.)}

A. unifasciatum Say. (bicolor Loew.) Common, DunnfieId VII, 11. Jamesburg VII, 4, Riverton VII, 3, Clementon VIII, \&, Atco VII, 9.

A. tener Loew. Dumnfield, Del. Water Gap VII, 15.

A. scintillans Loew. Princeton VII, 21, Avalon VI, 30, VII, 29.

A. psittacinum Loew. Avalon VI, 35 (Jn); Anglesea VII, 4 ( Lv).

A. variegatus Loew. Avalon VI, 30, Cape May VI, 22.

A. pallens Wied. New Jersey (Bt).

MESORHAGA Schiner. (APTORTHUS Aldrich.)

M. albiciliata Aldr. Types at Westville VII, 5, 20, 1891.

M. townsendii Aldr. Atlantic City VIII, 11.

\section{DIAPHORUS Mieig.}

D. mundus Loew. Avalon VII, 22, 29.

P. sodalis Loew. Westville VI, 6.

D. leucostomus Loew. Shark River VII, 12, Riverton IX, 11 (Jn): Anglesea $\mathrm{V}, 28$.

D. opacus Loew. Jameshurg VII, 4, Buena Vista VI, 11. 




\section{ASYNDETUS Loew.}

A. ammophilus Loew. Riverton VII, 30, Westville VIII, 19 (Jn); Egg Harbor VII, 10 (Coll).

A. syntormoides Wheelel'. Type taken at Avalon VIII, 22, '94 (Jn); Vineland VII, 29 (Coll).

\section{CHRYSOTUS Meigen.}

C. barbatus Loew. Trenton VIII, 21 (Hk).

C. obliquus Loew. Jamesburg, Ocean Co. V, Vineland VII, 2, Anglesea T, 28 (Coll).

CAMPICNEMUS Halid.

C. hirtipes Loew. Manahawkin IX, 5 (Hk).

\section{ARGYRA Macq.}

A. calcitrans Loew. Westville VI, 6, Clemmeton V, 30, VI, 3.

A. minuta Loew: Dumnfield, Del. Water Gap VII, 15.

A. aldrichi Johns. Long Branch VI, 11.

A. albicans Loew. Princeton VII, 21 (Jn); Riverton VI, 15 (Dke).

\section{LEUCOSTOLA LOEW.}

L. cingulata Loew. Dusnfield VII, 15, Shark Rivel V'II, 12, Woodbury YI, T.

\section{PORPHYROPS Meig.}

P. fumipennis Loew. Woolbury $\mathrm{V}, 14$.

P. melampus Loew. Westrille $Y, 19$, Lenola $V, 30$.

P. nigricoxa Loew. Lenola $\mathrm{r}, 31$.

\section{NEMATOPROTUS LOEW.}

N. venustus Melander. Mestville VI, 6.

\section{SYMPYCNUS Loew.}

S. lineatus Loew. Princeton VII, 21, Avalon VI, 30.

S. sp. nov. Riverton $\mathrm{T}, 20$.

\section{NOTHOSYMPYCNUS Wheeler.}

N. fortunatus Wheeler. Dunnfield, Del. Water Gap VII, 11, 13.

N. n. sp. Riverton $\mathrm{X}, 9$.

\section{NEURIGONA Rond.}

N. carbonifer Loew. (floridula Wheeler.) Type taken at Dover VI, 23, '92, Dunnfield VII, 15, Riverton VI, 20.

N. lateralis Say. (Saucropus superbiens Loew.) Riverton VII, 3, IX, 11 (Jn); Lucaston V, 30 (CG).

N. rubella Loew. (Saucropus) "New Jersey" (Bt); Orange Mts. 


\section{REPORT OF NEIT JERSEY STATE MUSEUM.}

\section{THINOPHILUS WahIb.}

T. neglectus Wheeler. Cape May VI, 6.

\section{MEDETERUS Fischer.}

M. princeps Wheeler. Types collected at Farmingdale VII, 14, '97.

M. nigripes Loew. "New Jersey" (A E S).

M. aberrans Theeler. Avalon VII, 22 (Wheeler).

\section{HYDROPHORUS Fallen.}

H. pirata Loew. New Jersey (Bt).

H. glaber Walk. Manahawkin IX, 5 ( $\mathrm{Hk}$ ).

H. viridiflos Walk. Atlantic City V, 6 .

H. æstuum Loew. Avalon VIII, 8 ( $\mathrm{Hl}$ ).

\section{LIANCALUS Loew.}

L. genualis Loew. "New Jersey" (Bt).

\section{DOLICHOPUS Latr.}

D. johnsoni Aldr. Type taken at Jamesburg VII, 4, 1891.

D. gratus Loew. Palisades (O S): Dunnfield VII, 8.

D. calcaratus Aldr. Type at Dover VI, 18, '92, Dunnfield VII, S.

D. setifer Loew. Passaic VI, 8 (Coll); Riverton IX, 9, Westville V, 19, Clementon V, 16.

D. acuminatus Loew. Westville V, 19, Clementon V, 30 .

D. albicoxa Aldr. Clementon V, 30, Anglesea V, 28 (Jn); Burlington and Ocean Cos. V (Sm).

D. palæstricus Loew. Dover VI, 18.

D. scapularis Loew. Iona IX, 12 (CG).

D. tonsus Loew. Clementon V, 30.

D. variabilis Loew. Dunnfield VII, 14, Westville VIII, 14.

D. cuprinus Wied. Dover VI, 16, Jamesburg VII, 4, Merchantville VI, 28.

D. virga Coq. Manahawkin IX, 5 ( $\mathrm{Hl}$ ) .

D. Iongipennis Loew. Dunnfield VII, 11, Merchantville VI, $2 S$.

D. ramifer Loew. Monmouth Co. VII, 31, Avalon VII, 22.

D. pugil Loew. (henshawi Wheeler.) Cape May VI, 23 (Vk).

D. cornutus Loew. Newark VI, 16, Riverton IX, 11, Westville V, 19, VII, 5, Avalon VII, 22, Anglesea V, 25.

D. lobatus Loew. Dunnfield, Del. Water Gap VII, 15.

D. scoparius Loew. Dover VI, 23.

D. quadrilamellatus Loew. Palisades VI (O S).

D. funditor Loew. Merchantville VI, 28.

D. incisuralis Loew. Merchantville VI, 28 . 


D. albiciliatus Loew. Dover VI, 23.

D. bifractus Loew. Jamesburg VII, 4, Ocean Co. (Sm); Westrille VIII, 18.

D. eudactylus Loew. Riverton VII, 3, Woodbury VI, 7.

D. vittatus Loew. Princeton VII, 21.

D. batillifer Loew. New Jersey (Bt).

D. reflectus Ald. Lenola V. 30. Jamesburg VII, 4 (Jn).

D. comatus Loew. Trenton VI. 1 (Coll); Jamesburg, Anglesea V, 28.

D. myosota O. S. Trenton VIll, 21 ( Hk).

\section{GYMNOPTERNUS Loew.}

G. flavus Loew. Dumnfield VII, S, Dover VII, 16, Westrille VII, 21.

G. spectabilis Loew. Westrille $V, 19$, Clementon $V, 30$.

G. scotias Loew. Shark River V'II, 12.

G. ventralis Loew: Shark River VII, 12.

G. debilis Loew. Jamesburg VII, 4, Merchantville VI, 28.

G. barbatulus 1,oew. Westrille VI, $1 \mathrm{~S}$.

G. exilis Loew. Merchantville V1, 28, Aralon VI, 30.

G. Iunifer Loew. Ocean Co. V (Sin).

G. albiceps Loew. Manahawkin IX, 5 (Hk).

G. subdilatatus Loew. Delaware Water Gap VII, S.

G. humilis Loew. Boonton VI, 2 (CG); Ocean Co. (Sm).

\section{HERCOSTOMUS Loew.}

H. vetitus Melander. Clementon $\mathrm{V}, 30$.

TACHYTRECHUS Stannius.

T. vorax Loew. Westrille VIII, 18 (Jn): Clementon $\mathrm{F}, 10$ (CG).

T. protervus Melander. Clementon $\mathrm{V}, 10$.

T. binodatus loew. Durham Pond, Morris Co. VIII, 18 (GG).

T. junctus Cog. Manahawkin LX, 5 ( $\mathrm{Hk})$.

\section{PELASTONEURUS Loew.}

P. vagans Loew. Princeton VII, 21, Clementon V, 30.

P. lugubris Loew. Cape May $\mathrm{VI}, 22$.

P. lamellatus Loew. Jersey City IX, 1S, Brigantine V'III, ż.

P. lætus Loew. Trenton V'III, 21 ( $\mathrm{Hk})$.

\section{Family EXIPID.E.}

The "dance-flies," so called because of their habit of congregating in swarms under trees or near shrubs and about brooks, dancing up and down. The mouth parts are often prolonged into a bealk, and they are 


\section{$75^{8}$ REPORT OF NEW JERSEY S'TATE MUSEUM.}

predatory in habit. The larvæ are predatory, and live under leaves and other decaying vegetable matter, where their prev occurs.

\section{PLATYPALPUS Maca.}

P. æqualis Loew. Dunnfield VII, 14, Merchantville VI, 28, Clementon VI, $16(\mathrm{Jn})$; Trenton $\mathrm{V}, 20(\mathrm{Hk})$.

P. mesogramma Loew. Dunnfield VII, S, 15, Merchantville VI, 28. Westville VII, 21.

P. trivialis Loew. Trenton V, 13 (Hlk).

P. pachycnema Loew. Westville VI, 6, Clementon V, 9, 16.

P. Iateralis Loew. Trenton VII, 25.

\section{TACHYDROMIA Meig.}

T. fenestrata Say. Boonton IX, 5, Clementon V, 2 (GG).

T. pusilla Loew. Riverton V, 1, Clementon V, 9.

T. brachialis Melander. Boonton IX, 9 (CG).

\section{HEMERODROMIA Meig.}

H. empiformis Say. Dunnfield VII, 11 (Jn); Trenton V, 20 (Hk).

H. defecta Loew. Avalon VI, 9.

H. capta Coq. Boonton IX, 5-9 (CG).

H. scapularis Loew. Clementon V, 16, 30.

LITANOMYIA Melander.

L. elongata Melander. Avalon VI, 9.

\section{CHIROMANTIS Rond.}

C. vocatoria Fall. Delaware Water Gap VII, 12.

\section{SYNECHES Walk.}

s. thoracicus Say. Ft. Lee VII, 4 (Dlie); Jamesburg VII, 4, Merchantville VI, 28, Atco VII, 12.

S. simplex Walk. Westville VII, 2, Atco VI, 18, Avalon VII, 22 (Jn); Clementon VI, VIII (div); 5-mile beach ( $\mathrm{Hk})$.

S. rufus loew. Ft, Lee VII, 4 (Dke); Atco VII, 9, Avalon VI, 30 (Jn); Buena Vista VII, 19 (Li).

s. hyalinus Coq. Westville VII, 21, Avalon VII, 22 (Jn); Malaga VIII, 4 (GG); Bamber VII, 13 (Dlke).

S. pusillus Loew. Jamesburg VII, 4 (Jn); Trenton VII, 7, Riverton VI, 27 ( $\mathrm{Hk})$.

\section{SYNDYAS Loew.}

S. polita loew. Riverton VII, 18 (CG); Manahawkin IX, 5 (Hk); Buena Vista VI, 11, Brown's Mills VI, 25 (Dke).

S. dorsalis Loew. Lucaston IX, 3 (Dke). 




\section{HYBOS Meig. (EUHYBUS Coq.)}

H. triplex Walk. Chester IX, 9 (Coll); Westville V, 30, Clementon V, 22, MIullica Hill, Atlantic City V, 15, Anglesea V, 28 (Jn); Ashland VII. 1.5 ( $\mathrm{Hli})$.

H. subjectus Walk. Jamesburg VII, 4, Riverton IX, 9, Clementon V, 30 , Atco VII, 12, Avalon VII, 22.

H. slossonæ Con. Del. Water Gap VII, 14, Riverton VIII, 11, Atco VI, 12.

H. reversus Walli. Del. Water Gap VII, 12, Jamesburg VII, 4.

\section{OEDALEA Meig.}

O. ohiensis Melander. (stigmatella?) Newark VI, 13.

LEPTOPEZA Macq.

L. flavipes Mleig. Dover VI, 18.

L. compta Coq. Riverton VI, 20) (Jn); National Park V, 6, Newhold VI, 30 (Dlie).

\section{PACHYMERIA Stephens.}

P. pudica Loew. Great Notch V, 4 (Dke).

\section{EMPIS Linn.}

E. spectabilis Loew. Caldwell (Cr); Riverton V, 1, Wenonah V, 14, Clementon IY, 15.

E. longipes Loew. "New Jersey" (OS).

E. loripedis Coq. Palisades V, 24 (Lv); Clementon V, 9 (Jn).

E. tridentata Coq. Woodbury VI, 7.

E. humilis Coq. Great Notch V, 4 (Dke).

\section{HILARA Meigen.}

H. testacea Loew. Clementon V, 9.

H. lutea L.oew. Clementon V, 10, 30.

H. leucoptera Loew. Avalon VI, 9.

H. macroptera Loew. Riverton VI, 20 (Hk).

H. mutabilis Loew. Clementon V, 10, Avalon VI, 9.

H. femorata Loew. Pemberton V, 10 (Hk); Avalon VI, 8.

H. tristis Loew. Dover VII, 17.

H. umbrosa Loew. Clementon VI, 2.

H. gracilis Loew. Dunnfield VII, 12 (Jn); Brown's Mills VI, 22 (Dke).

H. seriata Loew. Clementon V, 26.

H. trivittata Loew. Ashland V, 13 (Hk).

\section{GLOMA Meigen.}

G. n. sp. Clementon V, 30 . 


\section{REPOR'T OF NEW JERSEY STATE MUSEUM.}

\section{RHAMPHOMYIA Meigen.}

R. longicauda Loew. Dunnfield, Del. Water Gap VII, 12.

R. tersa Coq. Prospertown VI, 1 (Sm).

R. priapulus Loew. Clementon V, 9.

R. gracilis Loew. Dunnfield, Del. Water Gap VII, 11.

R. glabra Loew. Caldwell (Cr); Newark VI, 16 (Jn); Trenton VIr, 7 (Hk).

R. compta Coq. Clementon VI, 16.

R. basalis Loew. Clementon V, 9.

R. nana Loew. Del. Water Gap VII, 10, Clementon V, 10 (Jn); Riverton IV, 26 (CG).

R. pulla Loew. Clementon V, 30 ( Jn); Atco VI, 3 (Li); Wenonah V, 30, Merchantville V, 26 (Dke).

R. angustipennis Loew. Trenton V, 20 (Hk); Clementon V, 9, 30 (Jn); Brown's Mills V, 21 (Dke).

R. vittata Loew. Clementon V, 30 .

R. luteiventris Loew. Morris Plains VI, 24, Clementon VI, 3 (Jn); Brown's Mills V, 21 (Dke).

R. minutus Walk. Dover VI, 17 .

R. limbata Loew. Clementon V, 9, 10.

R. candicans Loew. Morris Plains VI, 24, Clementon V, 30, Avalon VI, 9.

R. manca Coq. Riverton VI, 19, VII, 3, Clementon V, 9 (Jn); Brown's Mills V, 13 (Dlie); Glassboro V, 19 (Hk).

R. pulchra Loew. Westville VI, 6 (Jn); Lahaway VII, 12 (Sm).

R. pusio Loew. Riverton V. 1 ( $\mathrm{Jn}$ ) ; Brown's Mills V, 12 (Dke).

R. polita Loew. Culver's Lake T, 29 (Coll); Riverton V, 29.

R. vara Loew. Newark V (Sm).

R. leucoptera Ioew. Riverton IV, 11, 20 (Jn); Lucaston IV, 10 (Dke).

R. scolopacea Say. Dusnfield, Del. Water Gap VII, 15.

R. clauda Coq. Clementon V, 10.

R. diversa Coq. Clementon $r, 9,10$.

R. macilenta Loew. Dinnfield VII, 11 (Jn); Lahaway VII, 5 (Sm).

R. irregularis Loew. Riverton IV, 20 (Jn); Iona IV, 21 (Dke).

R. mutabilis Loew. New Brunswick V1, $T(\mathrm{Sm})$; Clementon $V$, 10 , Wenonah $\mathrm{V}, 14$.

R. sordida Loew. Clementon V, 10.

R. umbrosa Loew. Boonton VI, 6 (CG).

R. brevis Loew. Iona IV, 20 (Dke).

R. amplipedis Coq. Brown's Mills V, 12 (Dke).

R. aperta Loew. Iona IV, 21 (Dke).

R. otiosa Coq. Fort Lee VII, 4 (Dke).

R. exigua Loew. Iona V, 16 ( $\mathrm{Hk}$ ).

R. rustica Loew. Riverton VI, 13 (Hk). 




\section{Fanily LONCHOP'TERIDA:}

The "spear-winged" flies, characterized by the pointed wings that induced the common name. Ther occur near water courses, and little is known of them or their habits. Only two species have been collected in New Jersey.

\section{LONCHOPTERA Meig.}

L. lutea Panz. New Brunswick VII, 20 (Sm): Westville VII, 4, Anglesea VII, 19 (Jn).

L. riparia Meig. Ocean Co. V (Sm); Manunuskin X, 20 (Dke).

\section{Family PHORID.E.}

Small, hunch-back flies, with large, broal wings, often observed running about on fallen leaves, windows, etc. The larva are cylindrical, ihinner in front than behind, and live in dearl snails, insects, decaying . fungi, vegetables, etc., and possibly in living insects.

\section{HYPOCERA LIOY.}

H. johnsoni Brues. Riverton Vlll, :31.

H. clavata Loew. National Park V, 6 (Dke); Clementon X, 3 (CG); Pemberton $\mathrm{V}, 10$ ( $\mathrm{Hl}$ ).

\section{APHIOCHAETA BrUES (PHORA).}

A. rufipes Neig. Del. Water Gap VII, 12, Riverton V, 23 (Jn); Stelton VI, 21 (Coll).

A. fasciata Fall. Delaware Water Gap VII, S.

A. picta Schiner. (interrupta Zett). Del. Water Gap V'II, 8, 12.

A. nigriceps Loew. Del. Water Gap VII, 12, Shark River VII, 12 (Jn); Ocean Co. V ( Sm).

A. albidihalteris Felt. Types bred from mushrooms, New Brunswick $(\mathrm{Sm})$.

A. fungicola Coq. Del. Water Gap VII, 12, Clementon V, 9.

A. agarici Lint. Fort Lee $(\mathrm{Lv})$.

A. scalaris Loew. Del. Water Gap VII, $12(\mathrm{Jn})$; New Brunswick VIII, 7 (Coll); Lucaston IX, 28 (Dlie).

A. epeiræ Brues. Dunnfield VII, 18, Avalon VI, 9.

A. flava Fallen. "New Jersey."

A. atlantica Brues. Atco.

A. minuta Aldr. Boonton I, 15 (GG).

A. microcephala Loew. Trenton IV, 19 (Hk). 


\section{REPORT OF NEW JERSEY STATE MLSEUM}

\section{TRINEURA Meig.}

T. aterrima Fab. Del. Water Gap VII, 8, Riverton V, 14, Clementon V, 9

\section{CONICERA Meig.}

C. atra Meig. Dunnfield VII, 8, Newark VI, 14.

\section{GYMNOPHORA Macq.}

G. arcuata Meig. New Jersey.

\section{Family PLA'TYPEZID王.}

Termed "flat-footed" flies because in the males the posterior tarsi are broad and much flattened. They are smaller than, but resemble a housefly, and occur in swarms near water courses, though locally. The larvæ live in mushrooms, and are not of economic importance.

\section{AGATHOMYIA Verrall.}

A. notata Loew. (Callomyia tenera Loew.) Riverton VII, 23, Westville VII, 2, 21 (Jn); "New Jersey" IV (A E S).

\section{PLATYPEZA Meigen.}

P. velutina Loew. Dunnfield VII, 11, Riverton VII, 30.

P. anthrax Loew. National Park VI, 3 (Dke).

P. tæniata Snow. Clementon IX, 9, X 3 (CG).

\section{I.amily PIPUNCLLID F.}

The "big-eyed" flies of Comstock, so called because of their relatively enormous head, which is made up almost entirely of eyes. The species are rare, and little is known of the larvæ, save that they are parasitic on bugs.

\section{CHALARUS WIK.}

C. spurius Fall. Del. Water Gap VII, 12 (Jn); Bamber VII, 13 (Dke).

\section{NEPHROCERUS Zett.}

N. dæckei Johns. Forest Hill (Wdt).

\section{PIPUNCULUS Latr.}

P. albofasciatus Hough. Westville VII, 2.

P. similis Hough. Westville VIII, 13.

P. atlanticus Hough. Newark VI, 14, Riverton VI, 18, Clementon V, 17 (Jn); Brown's Mills VII, 4 (Dlie). 


P. subvirescens Loew. Riverton VI, VII $\left(\mathrm{J}_{\mathrm{n}}\right)$; Delair VIIl, 14 (Dlie).

P. nigripes Loew. Newark IX (Wdt); Clementon X, 4 (Hk); Buena Vista VI, 10 (Jn).

P. nitidiventris Loew. Trenton $\mathrm{V}, 20$ (Hk); Riverton IX, 14 (Jn).

P. subopacus Loew. Newark VII (Wdt); Riverton VI, 1, VIl, 19 (Jn), Clementon $\mathrm{V}, 30$ ( $\mathrm{Hk}$ ).

P. pallipes Johns. Trenton VIII, 21 (Hk); Vildwood VIII, 27.

P. fuscus Loew. Trenton VII, 7, Wenonah VI, 23 ( $\mathrm{Hk}$ ).

P. cingulata Loew. Forest Hill (W'dt).

P. houghi Kertéz. Trenton V, 24 (Hli); Brown's Mills, V, 13.

\section{Fanily SIRPHID.E.}

These are "flower-flies," usually brightly colored and banded witl yel. low on a black, bronze or blue ground. They have very short, aristate or stylate three-jointed feelers, barrel-shaped bolles, and sonwhat flattened ablomen, varying from slender to broadly oval. Sometimes they are almost bare and resemble wasps in appearance and habits: at others they are hairy and resemble bees, even in the droning or buzzing noise that chey make. The mouth parts are formed for scraping and lapping only, and they feed upon loney or pollen.

In larval habits they vary greatly. Sonie are predatory and feed upon plant lice: these are usually winkled, pointed anteriorly, and live among their prey upon leaves of plants. Others feed in Hlant tissue, being more or less maggot or grublike; and yet others are scavengers, the larva feeding in the foulest excrementitious matter; these are usually furnished with a long breathing tube from the anal end, and are known as rattailed larvæ. Some few species seem to feed

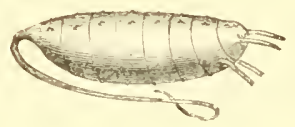

Fig. 313.-A "rat-tailed" larva.

upon pollen, and at least one form occurs between the leaf and stalk of corn, feeding upon the juices. Yet on the whole the species are beneficial.

\section{MICRODON Meig.}

M. globosus Fab. Riverton IX, 14, Westville VII, 2, IX, 10, Anglesea IX, 4 (Jn); Pemberton VII, \& ( Hk); DaCosta VII, 1-16 (Dke); Cape May VII, 31 (Vk).

M. megalogaster Snow. Clementon V.,30 (Jn); Wenonah VI, 23 (Hk).

M. tristis Loew. Ft. Lee (Osburn); Dover VI, 17, Newark VI, 14, Clementon V, $9(\mathrm{Jn})$; Brown's Mills VI, 22 (Dke).

M. aurifex Wied. Forked River MIs. VII, 9 (Fenninger).

M. rufipes IIacq. Laliehurst VII, 7.

\section{MIXOGASTER Macq.}

M. breviventris Kahl. Lucaston VIII, 27, IX, 14 (Dlie). 


\section{REPORT OF NEIT JERSEY S'TATE MUSEUM.}

\section{CALLICERA Meig.}

C. johnsoni Hunt. Glassboro IV, 29 (CG); Manumuskin IV, 28 (Dke).

\section{CHRYSOTOXUM Meigen.}

C. laterale Loew. IVestville IX, 10 (Jn); Clementon V, 30, X, 4 (Hk).

C. pubescens Loew. Caldwell VI, 15 (Cr); Westfield (Bueno); New Brunswick $(\mathrm{Sm})$; Woodbury IV, $2(\mathrm{Jn})$; Clementon IX, 7 (Hk); Atco IX, 19 (CG).

C. derivatum Wall. Riverton $1 \mathrm{X}, 8,14$.

\section{CHRYSOGASTER Meig.}

C. nigripes Loew. Orange (Loew); Morris Plains VI, 25, Riverton V, 10, Westville VI, 15 (Jn); New Brunswick (Sm); Bridgeport V, 20 (Dke); Trenton V, 21, Clementon V, 30 (Hk).

C. nitida Wied. Ft. Lee (Osburn); Trenton VII, 3, Clementon IX, 5 (Hk) : Jamesburg VII, 15, Westville V, 19, Anglesea VII, 19, Bridgeport V, 20. (Dke).

C. pictipennis Loew. Riverton IV, 26 (CG); Clementon V, 9, Lenola V, 30.

C. pulchella Will. New Brunswick V. 24 (Sm); Jamesburg VlI (Jn); Ashland VIl, 16 (Hk).

PSILOTA MeIg.

P. buccata Macq. Clemcnton V, 3 (Hk); Manumuskin IV, 28, Iona IV, 30 (Dke).

\section{PIPIZA Fall.}

P. modesta Loew. Delair X, 19 (Dke); Atco VII, 9, Clementon V, 30.

P. radicum Walsh \& Riley. (postica Will.) Newark VI, 14. Riverton VIII, 14, Clementon $\mathrm{V}, 30$ (Jn); Wenonah VI, 23 (Hk).

P. pulchella Will. Trenton $\mathrm{V}$. 26 (Hk); Lucaston V, 28 (Dke); Sandy Hook VIII, 11, Avalon VI, 9, Wildwood Y'III, 12, Cape May VI, 3.

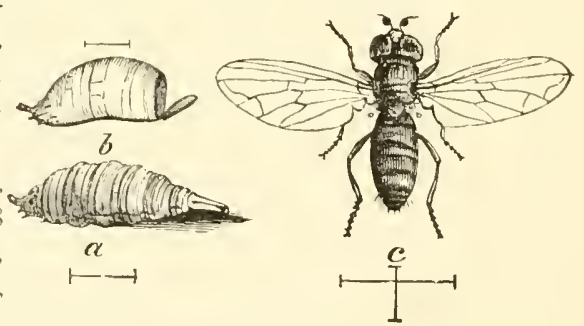

P. calcarata Loew. Dunnfield VII, 12, Riverton VII, 4.

Fig. 314.-Pipiza radicum; a root-louse Syrphid: $a$, larva; $b$, pupa; $c$, adult: all enlarged.

PARAGUS Latr.

P. angustifrons Loew. Jamesburg VII, 15, Westville VI, 15, Atco VII, 12, Anglesea VII, 19 (Jn); Ashland VII, 16 ( Hk). 


P. bicolor Fab. Ft. Lee (Osburn); Princeton VII, 21 (Jn); Clementon $\mathrm{X}, 4$ (Hk).

P. tibialis Fall. Ft. Lee (Osburn); Orange NIt. VIII, 29 (Coll); Dover VI, 23, Jamesburg VII, 4, Clementon VIII, 6, Atco VI, 4 (Jn); Trenton IX, $12(\mathrm{Hk})$.

\section{CHILOSIÁA Meig.}

C. similis Coq. Riverton IX, 20; Lucaston IX, \&, Clementon IX, \& (Jn); Iona $\mathrm{IX}, 12$ (CG).

C. pallipes Loew. Dunnfield VII, 11, 15, Caldwell VI, 15 (Jn); Paterson V. 3 (Osburn); Delair VIII, 18 (Dacke).

C. capillata Loew Clementon V, 9.

C. tristis Loew. Riverton IX, 11 (CG); Clementon IX, 5, X, 4 (Hk); Hammonton IX, 6, Ramber IX, 9, Manumuskin IX, 15, X, 8 (Dke).

C. comosa Loew. Garrett Rock, Paterson $\mathrm{r}, 3$ (Osburn); Clementon IV, 21 (Dke).

\section{MYIOLEPTA Newman.}

M. varipes Loew. Clementon VI, 2 (Dke).

\section{BACCHA Fab.}

B. tarchetius Walk. Riverton IX, 9 (CG); Westrille, VIII, $28(\mathrm{Jn})$; Clementon XiI (Hk): Weymouth VIII, 16 (Dke).

B. clavata Fab. Riverton IX, 11, Avalon VI, 9.

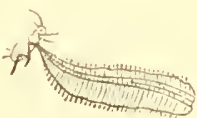

Fig. 3ะ5. - Syr phus larva cat ing a plant-louse.

B. lugens Loew. Mantmuskin X, 8 (Dke).

B. fascipennis Wied. (aurinota Harris.) Trenton IX. 3, Riverton IX, y (Hk): Ocean Co., Cumberland Co. IX, 1 (Sm).

B. cognata Loew. Dunnfield, Del. Water Gap VIl, 11.

\section{OCYPTAMUS Macq.}

O. fuscipennis Say. Trenton VII, 11 (Hi): Westville VII, 4, VIII, 14, Clementon VilI, 9 (.Jn); Lakewood (Lansing).

\section{PYROPHAENA Schr.}

P. rosarum Fab. Delaware Water Gap VII, 15.

\section{PLATYCHIRUS St. Farg. \& Serv.}

P. quadratus Say. Palisades VII, 10 (Lv); Jamesburg VII, 4, 15, Westville V, 19, VIII, 23 (Jn); Trenton VII, 5, Clementon V, 30 (Hk).

P. hyperboreus Stæger. Caldwell (Cr); Ft. Lee (Osburn); Elizabeth V, 6 (Kp); Jamesburg VII, 4 (Jn); Clementon V, 30 (Hk).

P. peltatus Meig. Merchantville V, 26 (Dlie).

P. chætopodus Will. Ft. I_ee (Osburn). 


\section{MELANOSTOMA Schiner.}

M. obscurum Say. Caldwell (Cr); Ft. Lee (Osburn); Riverton IV, 26 (CG) ; Westville VI, 15, IX, 10 (Jn).

M. mellinum Linn. Caldwell (Cr); Ft. Lee (Osburn); New Brunswick (Sm) ; Jamesburg VII, 4, Westville V, 19 (Jn); Trenton V, 21, Clementon $\mathrm{V}, 30(\mathrm{Hk})$.

\section{DIDEA Macq.}

D. fasciata Macq. (fuscipes Loew.) Jamesburg, Westville VIII, 21, Clementon V, 16, Ocean Co. V, 18 (Jn); Delair X, 19, Iona IV, 30 (Dlie).

\section{SYRPHUS Fab.}

S. arcuatus Fall. New Brunswick V, 3 (Sm); Camden IX, 14, Westville IV, 16 ( $\mathrm{Kp}$ ); Clementon X, 1 ( $\mathrm{Hl}$ ).

S. perplexus Osburn. New Jersey (Osburn).

S. ribesii Linu. Newark VI, 14, Westville VIII, 14, Cumberland Co. IX, 1.

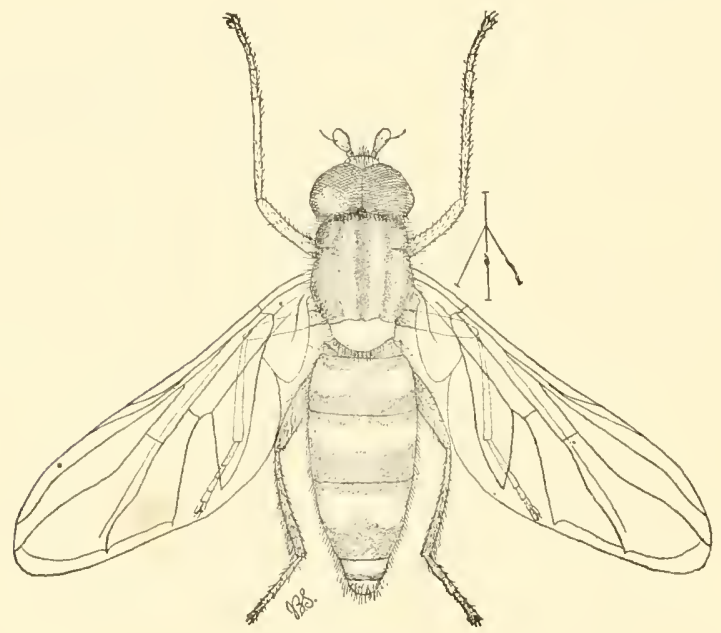

Fig. 3 I6.

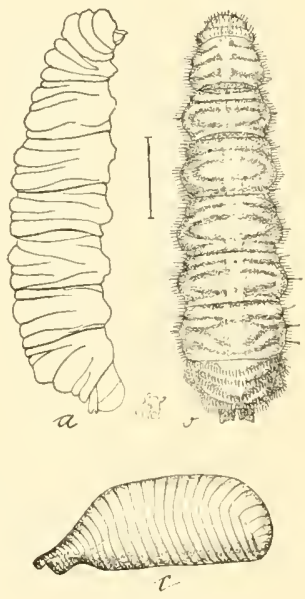

Fig. 317 .

Fig. 3r6.-Syrphus torr'us: much enlarged.

Fig. 317.- I arva $a$ and $b$, pupa $c$, of Syrphus torous: much enlarged.

S. torvus O. S. Caldwell (Cr); Camden V, 26 (CG): Westville IX, 13 $(\mathrm{Jn})$; Prospertown, common in Monmouth and Burlington Cos., feeding on the wheat-louse; the species of this genus are usually feeders upon plant-lice (Sm).

S. grossulariæe Meig. (lesueurii Macq.) Dunnfield VII, 14, Atco VI, 13 (Jn); New Brunswick VII, 9, Prospertown VI, 6 (Sm); Anglesea V, $31(\mathrm{Brn})$. 


S. amalopis O. S. Paterson V, 3 (Osburn).

S. diversipes Macq. Paterson V, 3 (Osburn).

S. americanus Wied. Del. Water Gap VII, 12, New Brunswick VI, 1 (Sm); Trenton V, 21 (Hk); Westville VI, 26, IX, 13, Merchantville VI, 28 $(\mathrm{Jn})$.

S. umbellatarum O. S. Riverton VII, 30 (Jn); Pemberton VII, 11 (CG).

S. abbreviatus Zett. Ft. Lee (Osbum); Clementon V, 11 (CG).

S. pyrostri Linn. Garret Rock, Paterson $\mathrm{V}, 18$; the first eastern record for this European species (Osburn).

S. xanthostomus Will. Ft. Lee (Osburn); Westfield (Bno); Lakehurst (Ds).

\section{ALLOGRAPTA O. S.}

A. obliqua Say. Caldwell (Cr); Highlands Vll, 11, Riverton IX, 5, Westville VI, 27, Atlantic City Vll, 15 (Jn); Pemberton V'lI, 8, Clementon IX, 5 ( $\mathrm{Hk})$.

\section{XANTHOGRAMMA Schiner.}

X. emarginata Say. Riverton IX, 20 (CG); Westrille (Jn); Clementon IX, $5(\mathrm{Hk})$; Lakehurst (Ds).

X. flavipes Loew. Norris Plains VI, 25, Newark VI, 16 (Jn); Palisades (Ds): Trenton VII, 5 (Hk).

$X$. æqualis Loew. Clementon $\mathrm{V}, 9,10$ (div): Malaga $\mathrm{V}, 1$ (Hk).

X. habilis Snow. Clementon LX, 11 (CG); heretofore regarded as western.

\section{MESOGRAMMA LOeW.}

M. polita Say. Caldwell (Cr); Sandy Hook VIII, 17, Riverton IX, 5, Gloucester VIlI, 14 (Jn); Trenton IX, 2, Clementon VII, 5 (Hk); this species is sometimes a corn pollen feeder in the larval stage, and occurred in large numbers in the summer of 1899 between the leaves and stalk of corn in Atlantic County.

M. marginata Say, Common throughout the State VI to X.

M. geminata Say. Ft. Lee (Osburn); Riverton IX, 5, Westville VI, 27, Clementon VIII, 9 (Jn); Ashland V, 13, Clementon IX, 5 (Hk).

M. boscii Macq. Avalon VII, 22.

\section{SPHEROPHORIA St. Farg. \& Serv.}

S. cylindrica Say. Common throughout the State $Y$ to IX.

\section{PELECOCERA Meig.}

P. pergandei Will. Riverton IX, 20 (CG); Lucaston IX, 28 (Dke).

\section{SPHEGINA Meig.}

S. keeniana Will. Clementon V, 16, VI, 7 . 


\section{REPORT OF NEIV JERSET STITE MUSEUM.}

S. lobata Loew. Dunnfield VII, 8, 15, Riverton VI, 19 (Jn); Clementon $\mathrm{T}, 30$ (CG).

S. rufiventris Loew. Caldwell (Cr); Lakehurst (Ds).

\section{NEOASCIA Will.}

N. globosa Walk. Princeton VII, 21, Westville V, 19, Buena Vista VI, 11.

N. distincta Will. Ashland V, 13 (Hk); Malaga IV. 3 (CG).

\section{RHINGIA Scopoli.}

R. nasica Say. Dover VI, 1S, Newark VI, 16, Westville VIII, 2S, Cumberland Co. IX, 1 (Jn); Clementon V, 30 (Hk).

\section{VOLUCELLA Geoff.}

V. evecta Walk. Dunnfield VII, 12, Orange Mts. VI, 13, Clementon V, 30. var. sanguinea Will. Clementon VI, 25 (Hk).

V. vesiculosa Fab. Dunnfield VII, 8, Riverton V, 29 (Jn); DaCosta VI, 4, Manumuslín VI, 23 (Dlie).

V. fasciata Macq. Bred from Cactus ("Opuntia"), obtained at Clementon; flies continued to emerge from V. 31 to VI, 16 (Kp): Anglesea VII, 10, Lahaway VII, $17(\mathrm{Sm})$; Avalon VI, S (Jn); this insect is found wherever the prickly pear occurs, and there is no outward indication of its presence, save that it is always associated with the larva of the Phycitid, "Melitara prodenialis."

\section{SERICOMYIA Meig.}

S. chrysotoxoides Macq. Ft. Lee (Erlwards): Newark VI, 16, Clementon Y, $9(\mathrm{Jn})$; Blackwood X, 10 ( Vk); Manumuslin IX, 15 (Dke).

\section{ERISTALIS Latr.}

E. tenax Linn. This is the common "drone" or "chrysanthemum fly," which occurs throughout the State until late fall, and is said to pollenize chrysanthemums. It resembles a honey bee so closely that most persons decline to handle it, therefore it is also called "dronefly." Its larva lives in the foulest excrement, and is a typical rat. tailed maggot.

E. æneus Fab. Boonton IX, T (GG); Orange, New Brunswick (Sm); Jamesburg, Clementon V, 10, Cape May VI, 14 (Jn); Ashland VII, 16, 5-mile beach VII, 20 (Hk).

E. dimidiatus Wied. Caldwell (Cr); Orange Mts., Westville VII, 5, Clementon $\mathrm{V}, 10(\mathrm{Jn})$; Lucaston IX, 9 ( Hk).

E. saxorum Wied. Caldwell (Cr); Trenton VII, 3 (Hk); Jamesburg VII, 4, Clementon V, 10 (div); Westville VII, 26, Anglesea VII, 19 (Jn).

E. meigenii Wied. Snake Hill IV, 26 (Lv); Westville VII, 5 (Jn); Trenton VII, $11(\mathrm{Hk})$. 


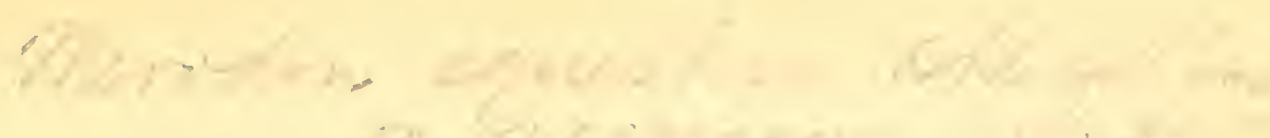

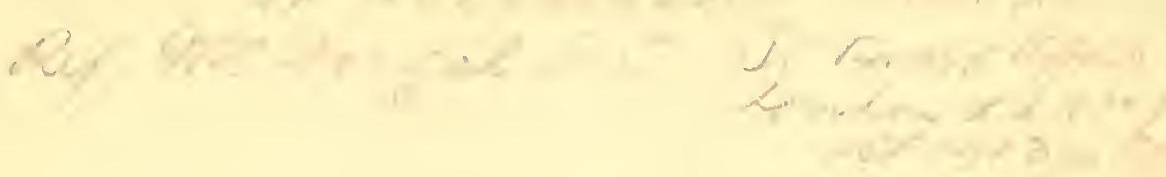



E. bastardi Macq. Snake Hill IV, $26 \mathrm{Lv}$ ) ; Newark (Sm); Trenton VII, 7 , Ashland VIII, 16 (Hli): Shark River VII, 12, Westville VII, 9, Anglesea VII, $19(\mathrm{Jn})$.

E. flavipes Walk. Boonton VII, 30 (GG); Ft. Lee (Osburn); Sandy Hook VII, 6 (Bt); Westville IX, 13, Clementon V, 16, Anglesea VII, 19.

var. melanostomus Loew. Trenton IX, 3 ( $\mathrm{Hk}$ ).

E. transversus Wjed. Orange Mits. VII, 4, Westville VII, 5, IX, 10 (Jn); Clementon V, VI, IX, X (div).

TROPIDIA Meig.

T. quadrata Say. CaldweIl (Cr); Westrille VII, 2, VIII, 23. Clementon $\mathrm{V}, 1 \mathrm{n}$ (Jn); Trenton VII, 11, 5-mile beach VI, 11 (HK).

T. calcarata Will. Westrille $V, 19$, Woodbury VI, 7 .

T. albistylum Macq. Gloucester Co. VII, 15 (Sm); Clementon (Hk).

\section{HELOPHILUS Meig.}

H. latifrons Loew. Caldwell $(\mathrm{Cr})$; Westville IX, 13 (Jn); Burlington Co. $(\mathrm{Sm})$; Clementon V, 11, 16 (CG).

H. similis Macq. Ft. Lee (Osburn): Newark $V^{r}$ (Sm); Sandy Hook, Jamesburg $\mathrm{V}$, 19, Westville IX, 9 (Jn); Clementon X. 1 (Hk).

H. latus Loew. Ft. Lee (Osburn); Merchantville $\mathrm{V}, 19,31$ (CG); Westville $\mathrm{V}, 19$, VIII, 16 (Jn).

H. chrysostomus Wied. Caldwell (Cr); Ft. Lee (Osburn); Jameslourg VII, 4 (Hli); Riverton V, 19, Westrille VIl, 2 (Jn); Prospertown V'I, $7(\mathrm{Sm})$.

H. distinctus Will Jamesburg VII. 4, Westrille V, 19 .

H. conostomus Will. Ft. Lee (Osburn); Cramer Hill V, 30 (CG); Westville V'II, 2.

H. divisus Loew. Westrille $\mathrm{V}, 14$.

H. integer Loew. Newark VI. 16, Westville VI, 15. VII, 21 (Jn); New Brunswick Vl, 5 ( $\mathrm{Sm})$.

H. hamatus Loew. Newark $\mathrm{V}$ (Sm); Elizabeth $\mathrm{V}, 15$ (Kp).

H. flavifacies Bigot. Dunufield, Del. Water Gap VII, 11.

MALLOTA Meigen.

M. posticata Fab. Morris Plains VI, 25, Clementon V. 16 (Jn); Caldwell (Cr); New Brunswick VII. 1 (Sm).

M. cimbisiformis Fall. Hewitt, Lakehurst (Ds): Trenton VII, 3 (Hli); Riverton VII, 3, Clementon V. 9.

\section{TRIODONTA Macq.}

T. curvipes Wied. Elizabeth V, 17, 21 $(\mathrm{Kp})$; Anglesea IX, 20, Cape May Fig. 3IS.-Mallota posticata and its VI, $14(\mathrm{Jn})$.
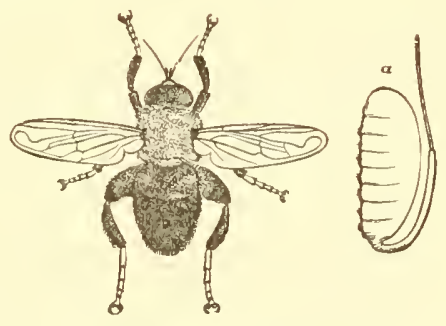
770 REPORT OF NEW JERSEY STATE MUSEUM.

\section{TEUCHOCNEMIS O. S.}

T. bacuntius Walk. Palisades (Lv); Ft. Lee (Osburn); Clementon V, (CG).

T. lituratus Loew. Great Notch V (Dke); Malaga V, 1 (Hk).

\section{PTERALLASTES Loew.}

P. thoracicus Loew. Ft. L.ee VIII, 30 (Dke); Gloucester Co. (Sm).

SYRITTA St. Farg. \& Serv.

S. pipiens Linn. Common throughout the State, V to IX.

\section{XYLOTA Meigen.}

X. pigra Fab. Ft. Lee (Osburn); Iona IX, 12 (CG); Shark River VII, 1, Clementon V, 10, Anglesea VI, 19.

X. tuberans Will. Brown's Mills VI, 5 (Dke).

X. bicolor Loew. Hewitt (Ds); Englewood (OS); Clementon V, 30 (CG).

X. ejuncida Say. Morris Plains VI, 23, Orange Mts. VII, 4. Clementon V, $16(\mathrm{Jn})$; Palisades VI, $28(\mathrm{Lv})$; Riverton V, 19, 5-mile beach VI, 11. VIII, 5 ( $\mathrm{Hk})$.

X. angustiventris Loew. Morris Plains VI, 25, Dunnfield VII, 15 (Jn); Trenton VII, 5, Anglesea VI, 11 (Hk).

X. metallifera Bigot. Clementon IV, 25 (Dke).

X. arithreas Walk. Jamesburg VII, 4, Merchantville VI, 28.

X. analis Will. Palisades VI, 7 (Lv); Clementon VI, 3 (Jn); Anglesea $\mathrm{V}, 28$ (Dke).

X. chalybea Wied. Hewitt (Ds); Ft. Lee (Osburn); Caldwell (Cr); Clementon V, 14 (CG); DaCosta VI, 3 (Dke).

X. fraudulosa Loew. Ft. Lee (Osburn); Clementon IX, 5, Anglesea VI, 11.

\section{CHRYSOCHLAMYS Rond.}

C. dives O. S. Westville VI, 15 .

BFACHYPALPUS Macq.

B. frontosus Loew. Newark V (Sm); Sandy Hook, Riverton V, 1 (Jn); Atco IV, $2(\mathrm{Kp})$; Clementon $\mathrm{V}, 5(\mathrm{Hk})$; Manumuskin $\mathrm{V}, 5$ (Dke).

B. rileyi Will. Riverto' IV, 14 (CG); Westville IV, 9, Clementon IV, 15.

B. sorosis Will. Clementon V, 14, 16; Manumuskin IV, 28 (Dlie).

\section{CRIORHINA HOffm.}

C. umbratilis Will. So. Amboy V, 10 (Jn); Merchantville V (Kp) ; Glassboro V, 19 (CG); Clementon V, 9-30 (div); Manumuskin V, 10 (Dlie).

C. analis Macq. Hewitt (Ds); Newark VI, 16 (Jn); Clementon V, 16, 30 (div); Malaga VI, 1 (GG). 


c. intersistens Walk. "New Jersey" (Walk); Clementon V, 30 (Hk).

c. verbosa Harris. Bergen Co. IV, $2 S$ (Kp); Glassboro III, 28 (CG).

c. decora Macq. Hewitt (Ds); Caldwell (Cr); Newark VI, 14, Clementon $\mathrm{V}, 16 \mathrm{(Jv})$; 'Trenton VII, 3 (Hk); Manumuskin $\mathrm{V}$, 10 (Dlie).

\section{MILESIA Latr.}

M. virginiensis Drury. (ornata Fab.) Dunnfield VII, 11. 15, Clementon VIII, 9, Cumberlanıl Co. IX, 1 (Jn); New Brunswick VIII, 7 (Sm); Clementon IX, 5, Malaga (Hk).

\section{SPILOMYIA Meig.}

S. longicornis Loew. Ft. Lee (Osburn); Riverton IX. 5, Westville IX, 13 (Jn); Clementon IX, 5 (Hk); Anglesea IX, $3(\mathrm{Sm})$.

S. fusca Loew. Dunnfield VII, $14(\mathrm{Jn})$; Hewitt (Ds); Palisades VIII, 14 (Dlie).

s. hamifera Loew. Caldwell (Cr); Ft. Lee (Osburn); New Brunswick - JI, $5(\mathrm{Sm})$; Trenton VII, 3 (Hk); Clementon V, 30 (CG).

\section{SPHECOMYIA Latr.}

S. vittata Wied. Caldwell (Cr); Riverton $\mathrm{V}$, 1, Clementon $\mathrm{T}, 9,16(\mathrm{Jn})$; Malaga $T, 1$ (CG).

\section{TEMNOSTOMA St. Farg.}

T. bombylans Fab. Ft. Lee (Osburn); Long Branch VI, 9 (Jn); Riverton $1 \mathrm{~V}, 4$. Clementon VI, 2 (CG); Trenton VII, 3 (Hk): Merchantville $\mathrm{r}, 26$ (Dke).

T. alternans Loew. Hewitt (Ds); Orange MIts. (Wdt).

T. trifasciata Robt. Anglesea VI, 11 (Hk).

T. pictula Will. Trenton VII, 3 (Hk).

\section{CERIA Fab.}

C. abbreviata Loew. Treuton VII, 3 (Hk); Merchantville V, 26 (Dke); Clementon $\mathrm{V}, 16,30$ (div).

\section{Family CONOPID.玉.}

Medium-sized flies, with a large head, comparatively small, chunky body and a long abdomen, which is often constricted at base and enlarged bulb-like at tip, as in certain wasps. They are called "thick-head" flies, and have rather slender antennx, though long for this series. The larvæ are parasites upon bees and grasshoppers.

\section{CONOPS Linn.}

C. brachyrhynchus Macq. Del. Water Gap VII, 11, Merchantville VI, 29, Atco VII, 12 (Jn); Clementon VIII, 15 (Hk). 


\section{REPORT OF NEW JERSEY STATE MUSEUM.}

C. bulbirostris Loew. Delair VIII, 5 (Dke); Westville V, 31 (CG); Atco VII, $12(\mathrm{Jn})$.

C. sylvosus Will. Caldwell (Cr); Clementon VI, 15 (Hk); Atco VII, 12 (Jn).

C. xanthopareus Will. Jamesburg VII, 4, Westville VIII, 16, Clementon V, 30 (Jn); Ocean Co. (Sm).

C. excisus Wied. Riverton VII, 3, DaCosta VII, 30 .

\section{PHYSOCEPHALA Schiner.}

P. tibialis Say. Dunnfield VII, S, Riverton VI, 20, VII, 30, Westville VII, 5 (Jn); Orange MIs. (Sm); Clementon VII, 15, Pemberton IX, 1 ( $\mathrm{Hk}$ ).

P. sagittaria Say. Ft. Lee (Bt); Orange Mts., Riverton IX, 11, Clementon VIII, 6, Anglesea VII, 15 (Jn).

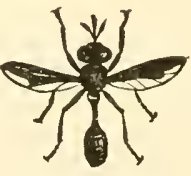

P. furcillata Will. Dunnfield, Del. Water Gap VII, 14.

P. marginata Say. Manahawkin IX, 5 ( $\mathrm{Hk})$.

Conops tibialis. Fig. 319 .

\section{ZODION Latr.}

Z. fulvifrons Say. Morris Plains VI, 25, Westville IX, 10, Clementon V, $10(\mathrm{Jn})$; Prospertown VI, $7(\mathrm{Sm})$.

Z. nanellum Loew. Buena Vista VI, 11, Atco VII, 12 (Jn); Hammonton VIII, 26 (Dlie).

Z. obliquefasciatum Macq. Riverton VII, 29, VIII 11.

Z. pygmæum Will. Avon IX, 27 (Hk); Iona IX, 12, Clementon VII, 29, Pemberton VII, 11 (CG).

\section{STYLOGASTER Macq.}

S. neglecta Will. Dunnfield VII, 11, Riverton VII, 30 (Jn); Wenonah VII, 22 (Dke); Clementon VII, 29 (Hk).

S. biannulata Say. New Jersey (Bt).

\section{DALMANNIA Desv.}

D. nigriceps Loew. Clementon V, 15-VI, 6 (div); Buena Vista Vl, 11 (Jn).

\section{ONCOMYIA Loew.}

O. abbreviata Loew. Delair VIII, 5 (Dke); Woodbury VI, 7, Merchantville VI, 28, Atco VI, 4 (Jn); Clementon VI, 25.

MYOPA Fab.

M. vesiculosa Say. Newark V (Sm); Jamesburg VII, 4, Buena Vista VI, 11 (Jn); Camden V; 18, Lenola IV, 29 (Kp); Riverton IV, 23 (CG). M. vicaria Walk. Riverton IV, 17 (Vk). 




\section{Family GESTRID.E.}

These are the "bot-flies," usually of good size, sometimes very large, and peculiar by having the mouth parts almost entirely aborted. Some are hairy, yellow, with rather a pointed abdomen; others are very plump, blue black. with a white bloom, and very formidable in appearance. The larre live in the nasal passages, in the stomach or beneath the skin of the animals infested by them, and often cause serious functional disturbance. They also lessen the value of the skins. The ordinary bots attacking horses and cattle lay their eggs on the hair of the animals, where they are likely to be licked off, and so brought into the mucus-lined passages; hence it is a good plan, where bots are numerous, to keep horses cleaned and brushed and to prevent their licking themselves. Bots beneath the skin should be treated with mercurial ointment, and after a day or two squeezed out through a sufficient incision. Where they infest the stomach, or get into the nasal passages, a veterinarian must be consulted.

\section{GASTROPHILUS Leach.}

G. equi Fab. The horse bot-fly, which spends the larval stage in the intestines, and is passed naturally when full grown; it pupates under ground and the eggs are laid on the hair.

G. nasalis Iinn. Caldwell ( $\mathrm{Cr})$.

HYPODERMA Clark.

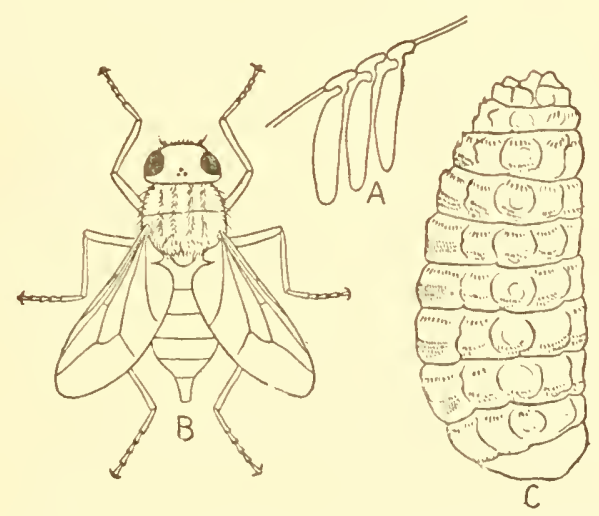

The ox bot, Hypoderma lineata: $a$, eggs attacher? to hair; $b, \mathrm{fly} ; c$, larva.

Fig. 320 ,

H. lineata Villers. The "Ox Warble"; occurs rarely throughout the State.

H. bovis De Geer. Atlantic City, Belvidere (U S Ag).

These species live under the skin and form tumors and ulcers. 


\section{CESTRUS Linn.}

O. ovis Linu. The sheep-bot. This species lives in the nasal and other head passages of sheep and causes a disease known as staggers, often resulting in death.

\section{CUTEREBRA Clark.}

C. buccata Fab. Ocean Co. VI (Sm); Dunnfield VII, 12. A species living under the sliin of rabbits.

C. horripilum Clark. Riverton VII, 6.

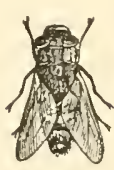

1

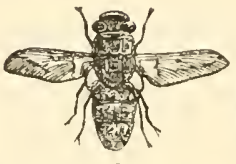

2

\section{Family TACHINIDF.}

The Tachina flies are almost all parasitic and of the very highest usefulness, since they form the chief control of many caterpillars. They resemble house-flies, flesh-flies, and blue-bottles in appearance, but are much more bristly; sometimes formidable-looking from the array of sharp points projecting in every direction. The bristle on the third antennal joint is always bare, and this is the best character for the recognition of the family.

These flies often lay their eggs on the outside of the caterpillar, usually just back of the head, where the larvæ cannot easily get at them. They are white in color and quite large enough to be easily seen.

Cut-worms are a common prey of these flies; sometimes of hundreds of such larvæ gathered not two per cent. will be free of these white eggs. In an army worm year sometimes scarcely one per cent. of the last brood is free. Anywhere from one to 100

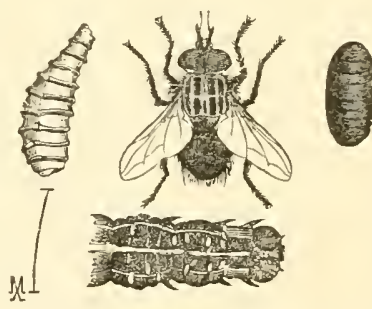

Fig. 422.- Tachinid parasite on cut-worms showing larva, pispa and adult, as well as the eggs on the anterior segments of a caterpillar.

grubs may infest a single caterpillar, depending upon the size of the host.

GYMNOCLYTIA B. \& B. (CISTOGASTER.)

G. immaculata Macq. Westville VI, 26 (Jn); Glassboro VII, 8 (CG); Clementon V, 30, IX, 5 ( $\mathrm{Hk})$.

G. occidua Walk. Dover VI, 17, Chester VII, 25, Westville, Atco VII, 12 (Jn); Middlesex Co. VII, 7, Jamesburg VII, 4 (Sm).

\section{GYMNOSOMA Meig.}

G. fuliginosa Desv. Caldwell (Cr); Woodbury VI, 7, Clementon VIII, \&, Buena Vista VI, 11, Anglesea VII, 19 (Jn). 


PHORANTHA Rond.

P. occidentis Walk. Trenton $\mathrm{V}, 5$ (Hk); Westrille V, 19, Woodbury VI, 7, Atco ViI, 9, Buena Vista VI, 11, Clementon V, 10.

P. nigrens V. d. W. Riverton X, 12, 20.

\section{ALOPHORA Desv.}

A. æneoventris Will. Clementon V, 16.

A. fumosa Coq. Dunnfield VII, 12, Clementon $\mathrm{r}, 16$.

A. subopaca Coq. Type at Woodbury VI, 7 , Riverton IX, 11.

A. pulverea Coq. Riverton X, 20.

A. diversa Coq. Riverton X, 12.

\section{POLISTOMYIA TOWNS.}

P. trifasciata Loew. (plumipes Fab.) Caldwell (Cr); Glassboro VII, 10, VIII, 2 (CG); DaCosta VII, 17 (Lt); Clementon IX, 7 (Hk).

\section{TRICHOPODA Latr.}

T. pennipes Fab. Cramer Hill VIII, 24, Merchantville VI, 2S, Shark River VII, 12, Anglesea VII, 19, DaCosta VII, 30; a parasite of the squash bug, "Anasa tristis" (Jn); Clementon IX, 5 (Hk).

\section{GALACTOMYIA TOWns.}

G. radiata Loew. Del. Water Cap VII, 10, Orange Mts. VII, 4, Westrille II, 15.

\section{MYIOPHASIA B. and B.}

M. ænea Wied. New Brunswick (Coll); Riverton IX, 20 (CG); Atlantic City VII, 15, Cape May VI, 22 (Jn); Lucaston IX, $9(\mathrm{Hk})$; a parasite of "Balaninus nasicus," "Conotrachelus juglandis" and "Splienophorus parvulus," all of which are injurious weevils.

M. setigera Town. Avalon VII, 22, Cape May IX, 25.

\section{CRYPTOMEIGENIA Br. and Berg.}

C. theutis Walk. Caldwell $(\mathrm{Cr})$; New Brunswick $\mathrm{V}(\mathrm{Sm})$; Riverton III, $20(\mathrm{Jn})$; 5-mile beach VI, $11(\mathrm{Hk})$; a parasite of "Lachnosterna in. versa."

PHASIOCLISTA TOWn.

P. metallica Town. Boonton VIII, 8 (GG); Anglesea IX, 1 (Jn).

\section{CERATOMYIELLA TOWn.}

C. conica Town. Westville VII, 2. 
776 REPORT OF NEW JERSEY STATE MUSEUM.

EULASIONA TOWn.

E. comstockii Town. Clementon VI, $6(\mathrm{Hk})$.

\section{ADMONTIA Br. and Berg.}

A. demylus Walk. Atlantic Co. VIII; parasite of the pine saw-fly, "Lophyrus abbotii."

A. degeerioides Coq. New Brunswick (Sm); Trenton V, 21 (Hk).

A. pergandei Coq. "New Jersey" (A E S); Pemberton VII, S (Hk).

A. polita Coq. Lucaston VI, 27 (Dke).

A. hylotomæ Coq. Chester IX, 16 (Coll); Newark X (Jn); Trenton VIII, $8(\mathrm{Hk})$.

A. nasoni Coq. Clementon IX, 11 (CG).

\section{CLAUSICELLA Rondani.}

C. johnsoni Coq. Riverton IX, 14.

ACTIA Desv.

A. pilipennis Fallen. Dumnfield VII, 15 (Jn); Trenton V, 21 (Hk).

\section{CELATORIA Coquillett.}

C. spinosa Coq. Dunnficld, Del. Water Gap VII, 12.

HYPOSTENA Meig.

H. dunningii Coq. New Iirunswick VI, 18 (Sm); Woodbury T, 14, VI, 7.

H. tortricis Coq. Avalon VII, 22.

H. variabilis Coq. Dunnifeld VII, 8, 15 (Jn); Trenton VII, 3, Clementon $\mathrm{V}, 30$ (HK) ; a parasite of "Pyrausta penitalis."

H. gilvipes Coq. Shiloh $\mathrm{X}, 1$.

H. floridensis Town. Trenton VII, 3 (Hk); Riverton IX, 11 (Jn).

H. flaveola Coq. Asbury Park VIII, 16.

MACQUARTIA DESV.

M. pristis Walk. Dunnfis]d VII, \&, 15 (Jn); New Brunswick VII, 1 S $(\mathrm{Sm})$; Trenton VII, \& ( $\mathrm{Hl})$.

POLIDEA Macq.

P. areos Walk. Chester IX, 1 (Coll).

HYPOCHAETA Br. and Berg.

H. longicornis Schiner. Dunnfield, Del. Water Gap VII, 15. 
. 



\section{METHYPOSTENA TOWns.}

M. barbata Coq. Trenton VII, 17 (Hk).

\section{LESKIA Desv.}

L. thecata Coq. Riverton VII, 3 (Jn); Clementon VI, 25 (HK).

L. analis Say. Riverton IX, 22 (Hk); Collingswood (CG); Westville VIII, 14, Clementon ViII, 6, Anglesea V, 28 ( $\left.J_{n}\right)$.

\section{LESKIOMIMA Br. and Berg.}

L. tenera Wied. Dunnfiejd VII, 9, Riverton VII, 31, Woodbury V, 15 $\left(J_{11}\right)$; Clementon IX, E. ( $\mathrm{Hl}_{\mathrm{i}}$.

\section{EUPHYTO TOWn.}

E. subopaca Coq. Type taken at Clementon V, 30 (Jn), VIII, 30 (Hk).

\section{LEUCOSTOMA Meig.}

L. senilis Town. Westrille VIII, 13, Woorbury VI, 7.

\section{SCIASMA Coq.}

S. rebulosa Coq. James'surg VII, 4. Riverton V, 14.

\section{HYALOMYODES TOWn.}

H. triangulifera Loew. Culver's Lake $V, 29$ (Coll); Riverton IX, 14, Clementon VI, 25 (Hli); Pemberton V, 10 (CG).

\section{CESTROPHASIA Br. and Berg.}

CE. ochracea Bigot. Orange Mts. (Jn); I ahaway VII, 5 (Sm).

CE. clausa B \& B. Clementon VI, $i$ (I.i).

CE. signifera V. d. Wuḷ. Clementon VI, 7 (Li); Atco VI, 3 (Jn).

\section{XANTHOMELANODES TOWn.}

X. arcuata Say. Clementron VIII. 31, IX, 8, Iona IX, 12 (CG).

X. atripennis Say. Hannonton VII, 6 (Dke); Lakehurst VII, 18 (Coll); Clementon [X, 5 (Hk); Lucaston IX, 8, Iona IX, 12 (CG).

\section{HEMYDA Desv.}

H. aurata Desr. Trentoll VII, 5 (Hk): Woodbury V'I. 7, Clementon VII, 29 (CG).

\section{EPIGRYMYIA TOWn.}

E. polita Town. Woodbury VI, T (Jn); Clementon V, 30, VI, 25 (Hk).

E. floridensis Town. Westville VII, 4 ( Jn); Riverton IX, 22, Clementon VII, 4 (Hk). 


\section{REPORT OF NEIT JERSEY STA'TE MUSEUM}

\section{SIPHONA Meig.}

S. geniculata DeGeer. Del. Water Gap VII, 8, Shark River VII, 12, Lenola V, 30, Ocean Co. V, Avalon VI, 30.

PAFAPLAGIA Br. and Berg.

P. spinulosa Bigot. Chester IX, 3 (Coll); Pemberton IX, 1 (Hk); Atlantic Co. VII, $24(\mathrm{Sm})$; Atco VI, 6 (Jn).

\section{CYRTOPHLCEBA Rond.}

C. horrida Coq. Westville IV, 19 (Jn); Clementon V, 3 (Hk).

\section{PLAGIA Meig.}

P. americana V. d. W. Trenton VIII, 11, Pemberton VII, 8 (Hli); Riverton VII, $31(\mathrm{Jn})$.

\section{SIPHOPLAGIA TOWn.}

S. rigidirostris V. d. W. Riverton IX, $22(\mathrm{Hk})$; Westville VIII, 13.

\section{DISTICHONA V. d. W.}

D. varia V. d. W. Atco VII, 12.

D. auriceps Coq. Trenton IX, 1, Clementon X, 4 (Hk); Belleplain IX, 8 (Dke).

\section{PACHYOPHTHALMUS Br. and Berg.}

P. signatus Meig. Jamesburg VII, 4; a parasite of "Pelopoeus cementarius."

P. floridensis Town. Woodbury VI, 7, Clementon V, 16, Atco VI, 18, Cape May VI, 6; also a parasite of "Pelopoens cementarius."

\section{SENOTAINIA Macq.}

S. rubriventris Macq. Riverton, IX, 5, Atco VII, 12, Atlantic City VII, 15, Buena Vista VI, 11 (Jn); Clementon V, 30, Lucaston IX, 9, Ashland VII, $16(\mathrm{Hk})$.

S. trilineata V. d. W. Trenton VII, 3 (Hk): Farmingdale VII, 14, Atco VI, 6, AvaIon VII, 29 (Jn); Clementon V-VIII (div); a parasite of "Sphecius speciosus."

\section{SIPHOSTURMIA COQ.}

S. rostrata Coq. Iona $\mathrm{V}, 26$ (Dke).

\section{TRIACHORA TOWns.}

T. unifasciata Desv. (Belvosia) Chester (Dkn); Trenton VII, 3 (Dke); West. ville VIII, 23, Clementon VI, X, a parasite of the army worm "Lencania unipuncta."

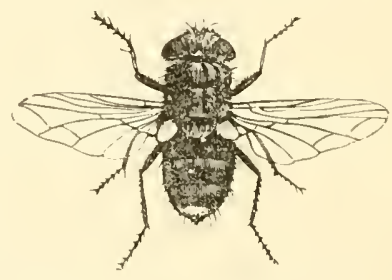

Fig. 323.-Triachora unifasciata. 


LATREILLIMYIA Towns.

L. bifasciata Fab. (Belvosia) Palisades TII, 13 (Lv); Westrille TII, 26, Clementon VIII, IX, 5 (Jn): Lakewood (Lansing); bred from "Eacles imperialis" and aIso infests "Citheronia regalis" and "Dryocampa rubicunda."

\section{APHRIA Desv.}

A. ccypterata Town. Jamesburg VII, 4, Clementon

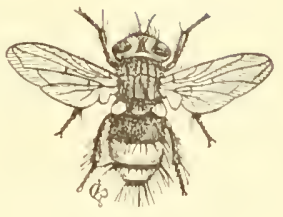

Fig. 324.-Latrcillimyia bifasciata.

V. 3" (Hk); Westville VII, 21, Atco VII, 12, DaCosta VII, 30, Buena V'ista VI, 11 (Jn).

OCYPTERA Latr.

O. carolinæ Desv. Caldwell ( $\mathrm{Cr})$; Westrille VI, 26. Atco VI. 18, Atlantic City VII, 15, Cape May VI, 14 (Jn); Pemberton VII, 8, Clementon VI, $24, \mathrm{X}, 4(\mathrm{HK})$; parasite of the army worm, "Leucania unipuncta."

O. argentea Town. Orange MIs. VII, 4, Westville TII, 2.

O. dosiades Walk. Dover VI, 25, Westrille VI, 26, Atco VII, 12, Atlantic City VII, 15, Anglesea VII, 19.

\section{LINNAEMYIA Desv.}

L. comta Fall. New Brunswick VIII, 11 (Coll); Trenton VII, 11, Pem. berton IX, 1. Aslland $\mathrm{V}, 13$ (Hk); Farmingdale VII, 14, Westville VI, 27, VII, $21(\mathrm{Jn})$.

\section{PANZERIA DESV.}

P. radicum Fab. Riverton $V, 3$ (GG); Clementon $V$ (div); a parasite of "Hyphantria cunea."

P. penitalis Coq. Riverton X, 9 (Jn); Clementon V'III. 31" (CG); a para. site of "Pyrausta penitalis."

\section{MACROMEIGENIA Br. and Berg.}

M. chrysoprocta Wied. Orange Mt. VIII, 29 (Coll): Trenton VII, 7 (Hk); Pemberton IX, \& (CG); Lakewood (Lansing).

\section{GYMNOCHAETA DesV.}

G. alcedo Loew. Newark VI, 16, Jamesburg VII, 4. Woodbury VI, 7, Riverton IV, 17, IX, 22 (CG); Clementon V, 30, VT, 25 (Hli).

\section{EXORISTOIDES COQ.}

E. slossonz Coq. Westrille V, 30, Clementon VI, 25, VII, 21.

\section{EUSISYROPA TOWn.}

E. blanda O. S. Dunnfield VII, 14, Farmingdale VII, 14 (Jn); New Hope VII, 10 (HK); a parasite on "Euclea cippus," "Nisoniades blizo" anu "Pyrameis cardui" (Coq). 


\section{SO REPORT OF NEIY JERSEY STATE MUSEUM.}

E. boarmiæ Coq. Atlantic Co. VII; bred from the oak tortrix, "Cacœcia fervidana" (Sm).

\section{EXORISTA Meig.}

E. helvina Coq. Dunnfield VII, 14, New Brunswick, Jamesburg, Anglesea VII, 11.

E. confinis Fall. Dunnfield VII, 12, Orange Mts. VII, 4, Farmingdale VII, 14, Riverton III, 3, Woodbury V, 14 (Jn); Trenton VIII, 11 (Hk); a parasite of "Lycæna pseudargiolus" and "Thecla calanus."

E. futilis O. S. Westville V, 19 (Jn); Ashland V, 13 (HK); a parasite of "Hadena apamiformis" and "Pyrameis atalanta."

E. griseomicans V. d. W. New Brunswick VIII, 14 (Sm); Anglesea V, 11 $(\mathrm{Hk})$; a parasite of "Orgyia leucostigma."

E. eudryæ Town. Clementon VII, 26; a parasite of "Acronycta hamamelis," "Agrotis ypsilon," "Eudryas unio," "Hyperchiria io" and "Pyrameis atalanta."

E. spinipennis Coq. Anglesea IX, 1.

E. dorsalis Coq. Riverton VIII, 25.

E. pyste Walk. Trenton V, 15 (Coll).

\section{EUPHOROCERA TOWn.}

E. claripennis Macq. Throughout the State III-VIII; a parasite of "Anisota senatoria," "Clisiocampa disstria," "Empretia stimulea," "Orgyia Ieucostigma," "Yanessa antiopa" and other Lepidoptera; also of "Epilachna borealis."

E. cinerea V. I. W. Clementon IV, 21 (Dke).

\section{PHOROCERA DESV.}

P. rufilabris V. d. W. Newark VI, Jamesburg VII, 4 (Jn); Trenton VIII, 11, Clementon VI, 24 ( $\mathrm{HK}$ ).

P. comstocki Will. Dover VI, 1 .

P. doryphoræ Riley. Parasite on potato beetle.

P. leucaniæ Coq. Riverton IV, 24 हi: (HK); Lucaston IV, 14 (DKe); a parasite of "Leucania unipuncta."

\section{FRONTINA Meig.}

F. ancilla Walk. Dunnfield, DeI. Water Gap VII, 15.

F. frenchii Will. New Brunswick (Sm) ; Lucaston IX, 9, Pemberton IX, 1 (Hk); bred from "Telea polyphemus" IV, 10 (Sm); brerl III, 17 from "Attacus cecropia" by

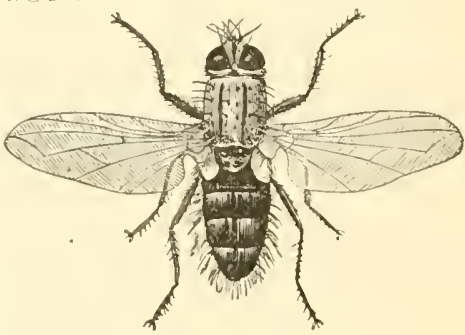

Fig. 325.-Phorocera doryphora. G. Valentine, of Hammonton; also parasite on "Anisota senatoria," "Clisiocampa americana," "Orgyia lencostigma," "Papilio turnus," etc. 



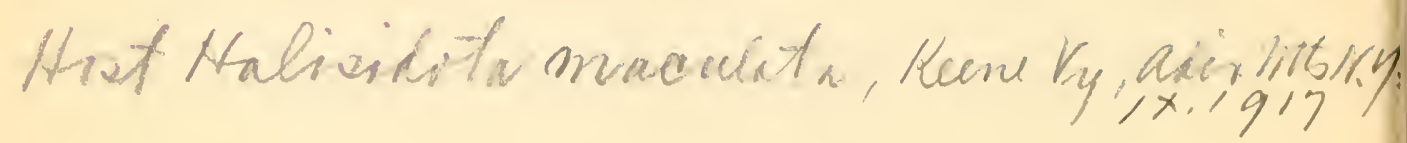


F. rubentis Coq. Clementon VIII, 6.

F. aletiæ Riley. Anglesea VI, 11 (Hk); a parasite of "Halisidota tessellata," "Dasylophia anguina" and "Orgyia leucostigma."

\section{STURMIA Desiv.}

S. albifrons Walk. Burlington Co. VII (Sm); Riverton IX, 5, 22; a parasite of "Ecpantheria scribonia" and "Lencarctia acræa."

S. inquinata V. d. W. Newark; bred from "Eacles imperialis" (Sm); also a parasite of "Protoparce celeus," "P. carolina," "Deilephila Iineata," etc.

S. normula V. d. W. Trenton IX, T, Clementon V, 30 (HK).

S. nigrita Town. New Brunswick V, 27 (Sm); Riverton V, 19 (HK).

S. australis Coq. New Hope VII, 10 (Hk).

\section{MASICERA Maç.}

M. tenthredinidarum Town. Jamesburg VII, 4, Woodbury VI, 7.

M. celer Coq. Dunnfield VII, S, 14, Westrille VI, 27.

M. eufitchiæ Town. New Brunswick (Sm); Clementon V, 5-30 (Hk); a parasite of "Eufitchia ribearia," and "Hyphantria cunea."

\section{ACEMYIA Desv.}

A. dentata Coq. Chester IX, 3 (Coll); Lucaston IX, 9 (HK).

\section{PSEUDOCHAETA COO.}

P. argentifrons Coq. Merchantville Vi, 28.

PROSPHERYSA V. d. W.

P. æmulans $\mathrm{T}, \mathrm{d}$. W. Anglesea.

\section{EUTHERA LOeW.}

E. tentatrix Loew. Clementon $\mathrm{V}, 30$ (Hk).

\section{TACHINOMYIA TOWn.}

T. robusta Town. (Tachina) Clementon V, II (Jn); Prospertown VI, 1 $(\mathrm{Sm})$; a parasite of "Agrotis ypsilon."

\section{TACHINA Meigen.}

T. mella Walk. Newark $\mathrm{Y}$ (Sm); Riverton IV, 16, Westville IV, 19, VII, $21(\mathrm{Jn})$; Clementon X, $4(\mathrm{Hk})$; Lakewood (Lansing): a parasite of "Orgyia leucostigma." "Pyrrharetia isabella," "Lencarctia acræa," etc.

\section{BLEPHARIPEZA Maca.}

B. leucophrys Wied. Dunnfield VII, 15 (Jn); Trenton VII, \& (HK). 
7S2 REPORT OF NEW JERSEI STATE MUSEUM.

\section{WINTHEMIA DesV.}

W. quadripustulata Fab. Throughout the State V-X; parasitic on "Attacus cecropia," "Telea polyphemus," "Orgyia leucostigma," "Leucania unipuncta," "Halisidota tessellata," "Protoparce celeus," etc.

PARADIDYMA B. and B.

P. singularis Town. Riverton VII, 3, IX, 25, Atco VII, 9 (Jn); Buena Vista VII, 10 (Li).

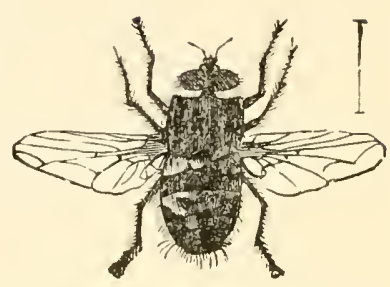

Fig. 326. - I'inthemin quadripustulata.

\section{METACHAETA Coq.}

M. helymus Walk. Shark River VII, 12, Riverton IV, 17, Westville VII, 21, Clementon V, 16, Buena Vista VI, 11, Anglesea VII, 19.

\section{PHORICHETA Rond.}

P. sequax Will. Atco VI, 4.

\section{CHAETOPLAGIA Coq.}

C. atripennis Coq. Type taken Westville VII, 2, '92; Riverton VI, 18.

\section{METOPIA Meigen.}

M. leucocephala Rossi. Trenton VII, 3, Clementon $\mathrm{V}, 30$ ( $\mathrm{Hk}$ ); Riverton VIII, 13 (Jn).

\section{ARABA Desv.}

A. tergata Coq. Riverton VI, 16, Shiloh, Cumberland Co. IX, 1.

\section{OPSIDIA Coq.}

O. gonioides Coq. Type taken Atlantic City VII, 15, '94; Shark River VIl, 12 (Jn); Anglesea VII, 20, VIII, 5 (Hk).

\section{HILARELLA Rond.}

H. decens Town. Jamesburg VII, 15 (Sm).

H. fulvicornis Coq. Del. Water Gap VII, 13, Atlantic City VIII, 28, Avalon VI, 29 (Jn); Pemberton VII, S, Clementon V, 30, Anglesea VI, 11 ( $\mathrm{Hk})$.

H. polita Town. Westville V, 19, Woodbury VI, 7 (Jn); Clementon V. 21 ( $\mathrm{Hk}$ ) ; Atco VI, 21 (CG).

H. siphonina Zett. Clementon (Jn); Lucaston IX, $\delta$ (CG). 




\section{BRACHYCOMA Rond.}

B. intermedia Town. Westville VII, 21, Anglesea VII, 16.

B. sarcophagina Town. Shiloh IX, 1.

B. sheldoni Cog Trenton $\mathrm{V}, 23$ (Hk).

\section{GONIA Meig.}

G. senilis Will. Split Rock Lalie V, 28 (GG); Trenton V, 21 (Hk); Buena Vista VI, 6 (Li); Clementon V. 12, Atco VII, 12.

G. capitata DeGeer. Caldwell (Cr); Westrille IV, 9, Clementon IV, VI, Buena Vista VI, 11; a parasite of cut-worms, - Hadena devastatrix," "Peridroma saucia," etc.

\section{SPALLANZANIA Desv.}

S. hesperidarum Will. Westrille V1, 27, VII, 2, Atco IX, 11, Anglesea VI. 25 (Jn) ; Clementon VI, 25 (Hk); a parasite of "Eudamus tityrus."

\section{GAEDIOPSIS Br. and Berg.}

G. ocellaris Coq. Newark VII (Sm); Trenton VII, 7 (Hk).

\section{CHATOGÆDIA Br. and Berg.}

C. analis V. d. Wulp. Trenton Vil, 11 (Hk).

\section{MICROPHTHALMA Macq.}

M. disjuncta Wieci. Boonton VIII, 28 (GG); Dunnfield VII, 15, Riverton IX, 11. Atco VII, 12, IX. 8; a parasite of "Lachnosterna arcuata."

\section{TRICHOPHORA Macq.}

T. ruficauda V. d. W. Caldwell (Cr); Trenton VIII, 11 (Hk); Westrille VII, 24, VIII, $14(3 \mathrm{n})$.

\section{CUPHOCERA Macq.}

C. fucata V. d. W. New Brunswick, Ocean Co. (Sm); Jamesburg VII, 4, Westville VI, 14, Atco IX, 11 (Jı); Clementon V, 30, VIII, 9 (Hk).

\section{PELETERIA Desv.}

P. robusta Wied. Boonton VII, 10 (GG); Glassboro VIII, IX, 6 (CG); Clementon VI, 25, X, 4 ( $\mathrm{Hk})$.

\section{ARCHYTAS Jaen.}

A. hystrix Fab. Caldwell (Cr); Shark River VII, 12. Westville VII, 10, Clementon VIII, 6 (Jn); Lucaston IX, $9(\mathrm{Hk})$; Atco IX, 8 (CG); Chester (Dn). 


\section{REPORT OF NEW JERSEY STATE MUSEUM.}

A. aterrima Desv. Throughout the State VI-X; a parasite of "Acronycta occidentalis," "Lagoa crispata," etc.

A. analis Fab. Clementon $\mathrm{X}, 4(\mathrm{Hk})$.

\section{E.CHINOMYIA Dumeril.}

E. decisa Walk. "New Jersey" (Coq).

E. florum Walk. Clementon V, 10, X, 4 (div); Atco VI, 4, Buena Vista VI, 11.

E. dakotensis Town. Lucaston VIII, 27 (CG); Atco IX, 11, Buena Vista VI, 11 (Jn); Clementon IX, 5, X, 4 (Hk); Anglesea (W).

\section{EPALPUS Rond.}

E. signiferus Walk. Split Rock Lake IV, 28 (GG); Caldwell (Cr); New Brunswick (Sm); Riverton IV, 17, Westville IV, 26 (Jn); Atco IV, 2 $(\mathrm{Kp})$.

\section{BOMBYLIOMYIA B. and B.}

B. abrupta Wied. Dunnfield VII, 4, Morris Plains (Jn); Caldwell (Cr); Ft. Lee (Bt); Camden IX, 2 (Kp); Trenton (U S Ag).

\section{Family DEXIIDA:}

The "nimble flies" of Comstock differ from the Tachinids which they otherwise resemble, in the longer legs and in having the bristle of the antennæ plumose to the tip. They are much less abundant, but are also parasitic in habit.

\section{MYOCERA Desv.}

M. simplex Big. (eremides Wlk.) Chester IX, 16 (Coll); Westville VI, 21, Woodbury VII, 7, A.tco VI, 18, Buena Vista VI, 11.

\section{PARAPROSENA B. and B.}

P. apicalis Desv. Del. Water Gap VII, 14, Dover VI, 7.

\section{MELANOPHORA Meig.}

M. roralis Linn. Del. Water Gap VII, 12, Clementon VIII, 6 (Jn); Avalon VI, VII (div).

DEXIA Meig. (ZELIA Desv.)

D. vertebrata Say. Delaware Water Gap VII, 8.

PHASIOPS COQ.

P. flava Coq. Caldwell $(\mathrm{Cr})$. 


PTILODEXIA B, and B.

P. tibialis Desv. Del. Watel Gap VII, 14, Orange MIts. VII, 4, Riverton V, 29, Clementon $\mathrm{V}, 16$ (Jn).

EUANTHA V. d. WuIp.

E. liturata Oliv. DaCosta VII, 30.

CHAETONA V. d. WuIp.

C. macroptera V. d. Wulp. Trenton VII, 7 (Hli).

THELAIRODES V. d. WuIp.

T. basalis Giglio-Tos. Dover VI, 23, Orange Mts.

T. cinereicollis V. d. Wulp. Riverton V. 30.

\section{THELAIRA Desv.}

T. leucozona Panz. Avalon VII, 22.

THERESIA DesV.

T. tandrec Desv. Chester (Sm); Malaga VIII, 4 (CG).

\section{Family S.IRCOOFH.IGID.E.}

These are the "ffesh flies," so called because they lay theil eggs on exposed meats or other animal matter, these eggs being either ready to hatch or actually hatched when laid. The antennal bristle is here plumose at the base and bare at tip, and as scavengers the insects are useful, some larvæ occurling in excrement and decay of all sorts.

\section{SARCOPHAGA Meig.}

S. carnaria Linn. Anglesea VII, 19, Cape May VI, 14. This is the common flesh-fly.

S. segra Walk. Westville V, 19, Anglesea VII, 19.

s. georgiana $\pi^{\top}$ i ed. C o $\mathrm{mmon}$ throughout the State.

S. sarraceniæ Riley. New Brunswick VIII, 7 (Coll).

S. incerta Walk. Lakehurst IX, 26 (Coll).

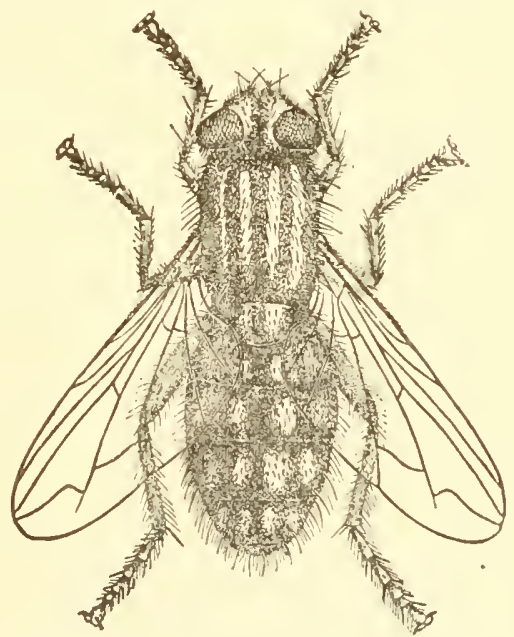

Fig. 327.- I flesh-fly, very much enlarged. 


\section{REPORT OF NEW JERSEY STATE MUSEUM.}

\section{HELICOBIA COq.}

H. helicis Town. Chester IX, 3, New Brunswick VI, 4 (Coll); Avalon VII, 22.

\section{Family MUSCIDE:}

This family contains the common house-fly, the stable fly, the horn-fly, the blow-fly and similar well-known insects. All of these have the antennal bristle hairy or plumose to the tip, but have no spines on the abdomen except at the end, about the anal segments.

The larvæ of these flies are true maggots, and with few exceptions they live in decaying material of all kinds, excrement, putricl meat, garbage, etc. Eggs are laid in masses and hatch in a few hours, the larval life being often scarcely a weel.

As scavenger's these insects are useful, but they become a nuisance in the house and in the stahle. While the majority of the flies gain their living by scraping and lapping liquid or pasty foods, a few of them are blood-suckers, the mouth being developed for piercing and sucking.

\section{POLLENIA Desv.}

P. rudis Fab. Common throughout the State V-VIII; this is a larger fly than the common house-fly, but is also found on windows, especially in late summer.

\section{CHRYSOMYIA Desv.}

C. macellaria Fab. Common throughout the State VI-VIII; the larva of this fly, known as the screw-worm, has done great harm in the southwest, but is not injurious in New Jersey.

\section{CYNOMYIA Desv.}

C. cadaverina Desv. Boonton X, 9 (GG); Westville IX, 9, Clementon V 9 (Jn); Lakehurst IX, 26 (Coll).

\section{CALLIPHORA Desv.}

C. erythrocephala Meig. Common throughout the State IV-X,

c. vomitoria Linn. This is the common "blow-fly" which occurs everywhere in the State, all season.

c. viridescens Desv. Westville IV, 9.

\section{LUCILIA Desv.}

L. cæsar Linn. Common throughout the State IY to XI.

L. sylvarum Meig. Jamesburg, Westrille V, 19, Atlantic City. Anglesea VII, 10. 


L. sericata Meig. Atlantic Highlands VII, 11 (Lv); Riverton IX, 9, Clementon T. $9(\mathrm{Jn})$.

\section{PROTOPHORMIA TOWN.}

P. terræ-novæ Desv. Dover VI. 17, Westville VI, 15 (Jn); Paterson V, 28 (Coll).

\section{PHORMIA Desv.}

P. regina Meig. Boonton IV, 12 (GG): Caldwell (Cr); New Brunswick (Sm); Jamesburg VII. 4, Westrille V, 15, Avalon VIII, 22 (Jn).

PSEUDOPYRELLIA Girschner.

P. cornicina Fab. Riverton IX, 9, Westville.

\section{PROTOCALLIPHORA Hough.}

P. splendida Macq. Ashland VII, 16 (HK).

\section{MORELLIA Desv.}

M. micans Macq. Newark VI, 16, Westville VII, 21, Shiloh IX, 1 (Jn); New Brunswick $(\mathrm{Sm})$.

\section{MUSCA Linn.}
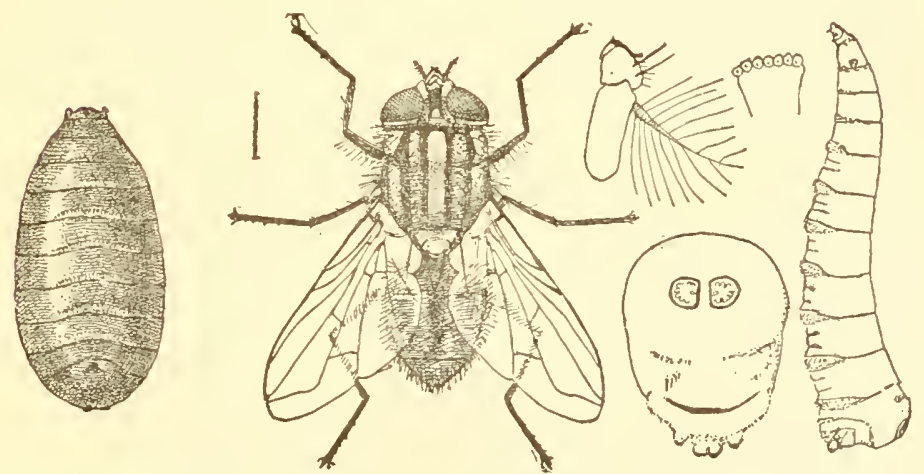

Fig. 328.-The "house fly," Musca domestica: larva with details at right: puparium at left; adult in center: all enlarged.

M. domestica Linn. House or "typhoid fly"; common throughout the State, all year around in sheltered places. It breeds preferably in horse manure, but is not averse to other excrementitious matter. 


\section{REPORT OF NEW JERSEY STATE MUSEUM.}

\section{GRAPHOMYIA Desv.}

G. maculata Scop. Jamesburg VII, 4, Clementon V, 12, VIII, $8, \mathrm{X}, 1$ (Jn); Riverton VII, 12 (CG).

\section{STOMOXYS Geoff.}

S. calcitrans Linn. The "stable-fly," common throughout the State; a great pest to cattle $(\mathrm{Sm})$.

\section{LYPEROSIA Rond. (HAEMATOBIA Desv.)}

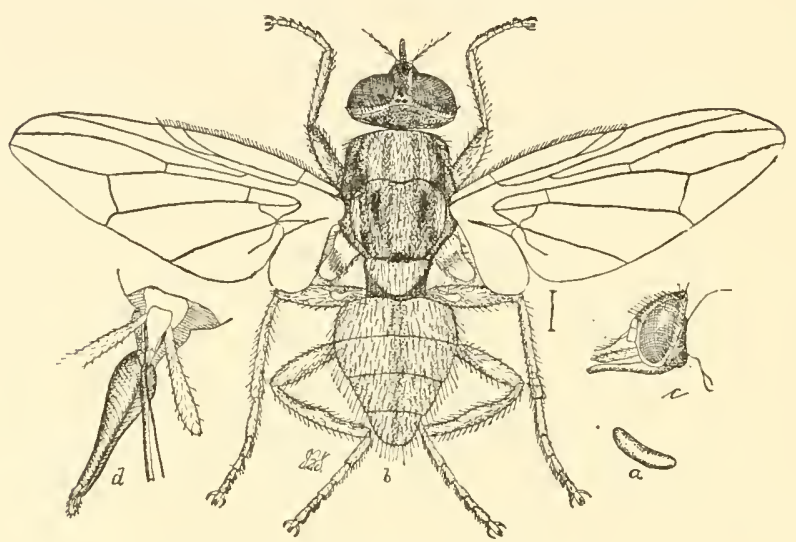

Fig. 329.-The horn fly, Lyperosia irritans: $a$, egg; $b$, fly; $c, d$, head and mouth parts: much enlarged.

L. irritans Linn. (serrata Desv.) "The horn-fly"; common throughout the State, but not so abundant as in previous years. Cattle may be protected from its attacks by sponging lightly with fish oil, to which a little crude carbolic acid has been added.

\section{MUSCINA Desv.}

M. stabulans Fall. New Brunswick VI, VII (Sm); Riverton IX, 20 (CG); Shark River VII, 9, Westville VII, 5.

M. assimilis Fall. New Brunswick, Monmouth County VII (Sm); Westville IV, 9 (Jn).

\section{MYOSPILA Rond.}

M. meditabunda Fab. Westville VII, 21, Clementon $\mathrm{V}, 10$.

\section{Family ANTHOMYIDFE.}

The flies of this family so closely resemble those of the preceding that, to the ordinary observer, they seem to be alike. Some of the species 


come into houses at times and are not usually noticed as being different from the common species.

In the larval stages the habits differ. Many, perhaps the most, are scavengers, as are the muscids; a few are parasitic, as are the Tachinids: quite a number feed in living vegetation, either in roots, as the onion and cabbage maggot, or mine in leaves, as in beets.

The root maggots are difficult to deal with, and not all methods are equally useful in all localities. Tobacco, hellebore, kainit, lime with carbolic acid or turpentine have all been used as repellants or destroyers with more or less Fig. 330. Hlead and scraping hooks of a root magsuccess.

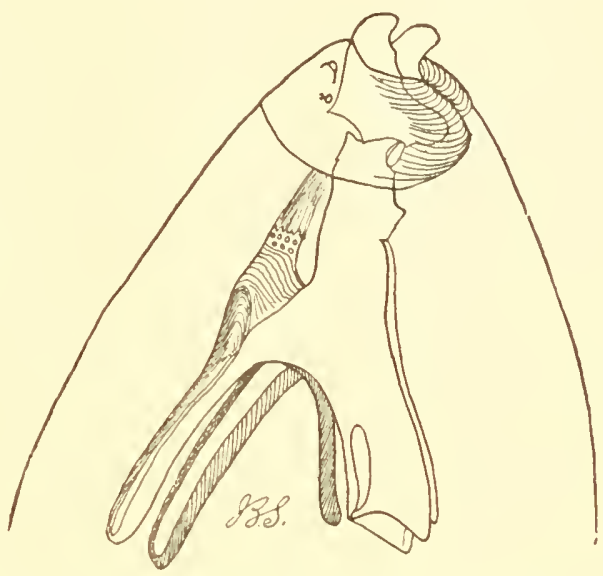

got, very nutteh enlarged.

Bisulphide of carbon injected into the soil has proved useful in some cases, and so has a tarred card surrounding a plant and resting on the surface. The farmer must usually learn by experience the particular method most useful in his locality.

\section{HYDROTAEA DESV.}

H. dentipes Fal). Pemberton V, 10 (Hdi).

H. armipes Fall. New Brunswick (Sm): Rirerton V, 14, Avalon VII, 22 (Jn); Pemberton V, 10 (CG).

H. impexa Loew. Dunnfield, Del. Water Gap VII.

H. metatarsata Stein. Clementon V, 3 (Hli).

\section{OPHYRA DESV.}

O. leucostoma Wied. Boonton VII, 19 (GG); New Brunswick VI, 1 (Sm); WVestville VII, 21 DaCosta VII, 19, Shiloh IX, 1.

\section{HOMALOMYIA Bouché.}

H. canicularis Linn. New Brunswick VII, Burlington Co. (Sm); Delair III, 1, bred from nest of "Vespa germanica" (Dke).

H. scalaris Fab. Del. Water Gap VII (Jn); New Brunswick (Sm).

H. incisurata Zell. Shark River VII, 12.

H. fasciculata Loew. Delaware Water Gap VII. 


\section{REPORT OF NEIV JERSEY STATE MUSEUM.}

H. manicata Meig. (acra Walk.) Caldwell (Cr); Lucaston IX, 2 (Dke).

H. fuscula Fall. Forest Hill VIlI (Wdt).

HYETODESIA Rond.

H. houghii Stein. Del. Water Gap VII, 11, Woodbury VI, 7.

H. leucorum Fall. (pylone Walk.) Del. Water Gap VII, 8, Clementon V, 16 (Jn); Merchantville V, 26, VI, 4 (Dke).

H. errans Meig. Delaware Water Gap VII, 14.

H. serva Meig. Delaware Water Gap VII, 12, 14 .

H. rufitibia Stein. Cape May IX, 21 (Dke).

H. pallidula Coq. Delaware Water Gap VII, 12.

H. pruinosa Macq. Woodbury TI, 7 (Jn); Manumuskin X, 8 (Dlie).

H. umbratica Meig. Forest Hill VI (Wdt).

H. proxima V. d. Wulp. Newark V (Wdt).

H. varipes Coq. Iona IX, 12 (CG).

\section{LASIOPS Meig.}

L. cunctans Meig. Newark V (Wdt).

\section{MYDAEA Desv.}

M. obscuripennis Stein. Clementon IV, 25 (Hk).

\section{SPILOGASTER Macq.}

S. pagana Fab. Del. Water Gap TII, 14, Newark VI, 16, Merchantville VI, 21, Westville VII, 21.

S. fusca Stein. Atco VI, 6.

S. abiens Stein. Delaware Water Gap VII, 11.

S. Iysinoë Walk. (amœba Stein.) Riverton V, 29.

S. humeralis Zett. Westville VI, 6 (Jn); Merchantville V, 26 (Dlie).

S. urbana Meig. Del. Water Gap VII, 4 (Jn); Orange Mts. VII, 1 (Wdt).

S. demigrans Zett. Atco VI, 6.

S. obscurinervis Stein. New Brunswick VI, 1 (Sm); Brown's Mills V, 21 (Dke).

S. socialis Stein. Orange Mts. V (Wdt); Trenton VII, $4(\mathrm{Hk})$.

S. crepuscularis Stein. Del. Water Gap VII, \&, Westville VIII, 14.

S. diruta Stein. Princeton VII, 21, Shiloh IX, 1.

S. uniseta Stein. Malaga IX, 15 ( Hk).

\section{LIMNOPHORA Desv.}

L. æquifrons Stein. New Brunswick (Sm). 


L. narona Walk. (cyrtoneurina Stein.) Toms River IX, 22 (Dle); Sea Isle City VII, 22 (Jn); Anglesea VII, 12 (Coll).

L. arcuata Stein. Riverton IX, 29, Manumuskin X, 8 (Die).

L. discreta Stein. Lncaston IX, 28 (Dlie).

\section{ANTHOMYIA Meigen.}

A. pluvialis Linn. Great Notch V, 5 (Dlie); New Brunswick VIII, 5 (Coll): Trenton VIII, 11 (Hk).

A. albicincta Fall. Jamesburg. Farmingdale VII, 14, Atco IX, 9.

A. radicum Linn. This is the radish maggot, and often decidedly troublesome.

A. pratincola Panz. Jamesburg VII, 4 (HK); Atco VII, 9 (Li); Iona V, 24 (Dlie); Lahaway VIII, 1 (Sm).

A. latitarsis Zett. Del. Water Gap VIII, 15 (Jn); Manumuskin X, 20 (Dke).

\section{HYDROPHORIA Desv.}

H. ambigua Fall. Fort Lee VII, 4 (Dke).

H. divisa Meig. DaCosta YII, 30 (Dke).

\section{HYLEMYIA DesV.}

H. lipsia Walk. Del. Water Gap VII, 12, Dover VI, 18 (Jn); Ft. Lee TIl, 4 (Dke); Woodbury V, 14, Clementon V, 30, Iona VI, S, Avalon VII, 29 (Jn).

HAMMOMYIA Rond.

H. unilineata Zett. Trenton IV. 16 (Coll).

\section{EUSTALOMYIA KOW.}

E. vittipes Zett. Del. Water Gap VII, 8 (Jn); National Park V, 20 (Dke): Iona IX, 12 (CG).

\section{EREMOMYIA Stein.}

E. cylindrica Stein. Riverton $\mathrm{X}, 12$ (Jn),

\section{PHORBIA DESV. (CHORTOPHILA RONd.)}

P. fusciceps Zeit. (cilicrura Rond.) Palisades IV, 4, Highlands VII, 11 (Lv) ; Jamesburg VII, 4, Riverton IX, 25, Westville VII, 2 (Jn); Burlington Co. V, Cumberland Co. ( $\mathrm{Sm}$ ). A general feeder in roots of cabbage, raddish, onions, seed corn, etc., etc.

P. cinerella Fall. Newark $V$. New Brunswick (Sm).

P. lavis Stein. Riverton VII, 24. 


\section{REPORT OF NEW JERSEY STATE MUSEUM.}

P. brassicæ Bouché. The common cabbage maggot; occurs throughout the State, some seasons very abundantly.

P. cepetorum Mead. imported onion maggot often injurious throughout the State.

P. ceparum Meig. (antiqua Schiner.) The common onion maggot; often a pest in South Jersey.

P. anane Walk. Newark VI, 16.

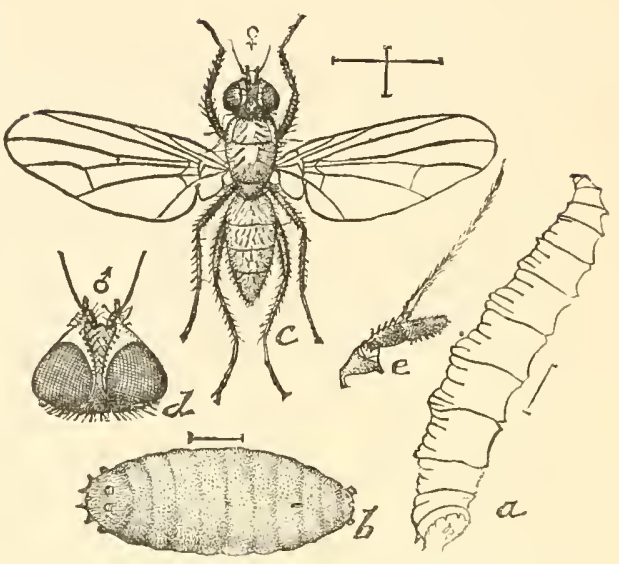

\section{PEGOMYIA Macq.}

P. vicina Lintner. Richfield

Fig. 33r.-The cabbage maggot, Phorbia brassica: $a$, larva; $b$, pupa; $c$, adult: all enlarged.

VI, 7 (Coll); Farmingdale VII, 14, Westville VII, 21; this is one of species mining the leares of beets in the larval stage.

P. latitarsis Stein. Delaware Water Gap VII, 15.

P. unicolor Stein. Delaware Water Gap VII, 15.

CHIROSIA Rond.

C. capito Coq. Lucaston IX, 28, Hammonton IX, 6. Toms River IX, 22, Manumuslin X, 21 (Dle).

\section{HOPLOGASTER Rond.}

H. nigritarsis Stein. Woodbury V, 14, Clementon V, 30, VIII, 11, Avalon VII, 29.

TETRACHAETA Stein.

T. unica Stein. Avalon VIII, 8 (CG).

TETRAMERINX Berg.

T unica Stein. Atlantic City VII, 21 (Dke): Ocean City V, 7 (Jn).

\section{PHYLLOGASTER Stein.}

P. cordyluroides Stein. Aralon VII, 19 (Hk).

\section{CARICEA DesV.}

C. antica Walk. Ocean County V (Sm); Westville VII, 5, Anglesea VII, 19, Sea Isle City VII, 22. 




\section{CEENOSIA Meigen.}

C. tibialis Stein. Anglesea IV, 26 (Sm).

C. nivea I oew. Del. Water Gap VII, 15, Atco VII, 12. Aralon VII, 29, Anglesea VII, 19 (Jn); Lucaston IX, 23 (Dlie).

C. calopyga Loew. Merchantville VI, 28 (Jn); Delair X, 19 (Dke).

C. ausoba Walk. (aurifrons Stein.) Passaic VI, \&, Westrille V, 24, Shiloh IX, 1 (Jn); Merchantville $\mathrm{V}$. 26 (Dke).

C. lata T'alk. (canescens Stein.) Riverton VI, VII (CG); Lucaston V. 2S, IX, 12 (Dlie); Clementon $V, 10$, Atlantic City VII, 15, Anglesea Y II, $19(\mathrm{Jn})$.

C. nudiseta Stein. Ft. Lee VII, 4, Iona V'l, 8 (Dlie); Anglesea V. 28 (Sm).

C. triseta Stein. Orange MIts. $\mathrm{I}^{+}\left(\mathrm{W}^{\prime} d t\right)$; Jamesburg VII, 4.

C. sexnotata Meis. Pemberton V. 10 (Hk).

c. fuscopunctata Macq. New Brunswick VII (Sn).

c. flavicoxa Stein. Clemeuton $\mathrm{r}, 10$ (CG).

C. antennalis Stein. Lucaston VIIl, 27 (Dlie).

C. hypopygialis Stein. Culver's Lake V. :9 (Coll): Delail VIlI, 18 (Dlie).

c. verna Fab. Lucaston T, 28 (Dlie).

\section{DEXIAPSIS Pok. (LISPOCEPHALA Stein.)}

D. lacteipennis Zett. Delaware Watel Gap VIl, 15.

\section{SCHCENOMYZA Haliday.}

S. dorsalis Loew. Ocean Co. V, Anglesea V, 28 (Sm); Manunuslin 1X, 15 (Dlie).

S. chrysostoma Loew. Shark River VII, 12, Riverton IV, 30.

LISPA Latr.

L. uliginosa Fall. Jamesburg VII, 4 (Jn); Pemberton VII, S (Hl); DaCosta VII, 20 (Dke).

L. albitarsis Stein. Trenton VIII, 11, Clementon $\mathrm{X}, 18$ (Hk).

L. hispida. Walk. Iona VI, S, Lucaston IX, 28 (Dke).

L. consanguinea Loew. Brown's Mills X, 6 (Dke): Trenton, Clementon X. $1 \mathrm{~S}(\mathrm{Hk})$.

L. tentaculata DeGeer. Riverton XI, 28 (Jn); Trenton, Clementon X, 18 ( $\mathrm{Hk})$.

L. polita Coq. Clementon X, 18, Trenton ( $\mathrm{Hl}$ ).

L. sociabilis Loew. Trenton VIII, 5 ( $\mathrm{Hk})$.

L. palposa Walk. Trenton VIII. 21, Avalon VIII. 8 (Hk).

\section{FUCELLIA Desv.}

F. fucorum Fall. New Brunswick III, 27, Anglesea IV. 11 (Coll); Riverton $\mathrm{V}, 1$, Hainesport III, 26 (Dke); Clementon IV, 15 (Jn). 


\section{Family SCATOPHAGIDE.}

Resembles the Borborida and differentiated from it by characters obvious to the specialist only. The larval habits are various, a number occurring in stems of "Rumex," but they are not at any time economically important.

\section{CORDYLURA Fall.}

C. confusa Loew. Newark VI (Wdt); Seaside Park V, 16 (Vk).

C. adusta Loew. Ft. Lee VII, 4 (Dke).

C. carbonaria Walk. Ashland V, 13 (Hk).

C. latifrons Loew. Shark River VII, 12, Westville V, Riverton VI, 19.

c. setosa Loew. "New Jersey" (A E S).

C. pleuritica Loew. Newark VI, 6, Clementon V, 12.

C. præusta Loew. Westville VI, 12, Clementon V, 30.

C. gracilipes Loew. Del. Water Gap VII, 12, Woodbury V, 14, Clementon V, 9 (Jn); Boonton VI, 2 (GG); Ashland V, 13 (Hli).

C. gilvipes Loew. Manumuskin IV, 2, National Park V, 6 (Dke).

\section{PARALLELOMMA Becker.}

P. varipes Waik. (bimaculata Loew.) Westville VII, 2, Clementon V, 30, Buena Vista VI, 7.

PSELAPHEPHILA Becker.

P. similis Coq. Glassboro V, 19 (Hk).

\section{HYDROMYZA Fallen.}

H. confluens Loew. Boonton VIII (GG).

\section{SCATOPHAGA Meig.}

S. stercoraria Linn. Newark VI, 17, Aralon VI, 30, Anglesea V, 28 (Jn); Camden IV, 18 (Kp).

S. furcata Say. New Brunswick IV, 20, Jamesburg IV, 8, V, 14 (Sm); Camden IV, 18 (Kp).

S. pallida Wlk. Delaware Water Gap TII, 14.

s. cerea Coq. Orange Mts. V (Wdt).

\section{Family HETERONELRID A.}

Small flies, with a large hemispherical head, the front broad and bristly to the base of the antennæ, which are short. Abdomen elongate, narrow, somewhat compressed, wings broad and long, legs long. The larvæ are slender, cylindrical, and live in decaying wood, under barli of trees, etc. 



\section{THE INSECTS OF NEII HERSEL. T\%}

\section{HETERONEURA Fallen.}

H. Iatifrons Loew. Dunnfield VII, S (Jn); Jamesburg VII, 15 (Sm).

H. albimana Meig. Delaware W'ater Gap VII, 12.

H. pictipes Zett. Riverton V, 14, Westrille VI, 6.

H. melanostoma Loew. New Brunswick V, 28 (Sm) : bred from decaying mood, Atco (Dke).

\section{CLUSIA Haliday.}

C. lateralis Walk. (spectabilis Loew). Palisades, Jamesburg VII, 4 Anglesea $\mathrm{V}, 2 \mathrm{~s}$ (Dlie).

C. flava Meig. Ft. Lee IV (Ly); Jamesburg VII, 15 (Sm).

$$
\text { Family HELOMTZID.E. }
$$

The species of this family have the abdomen Iong, broad and more or less flattened, the male genitalia being somewhat prominent. The wings are comparatively large and the costa is bristly. The larræ live in dung of bats, rabbits, truffles, decaying wood, etc., and are not in any way harmful.

\section{HELOMYZA Fallen.}

H. longipennis Loew. Dunnfield, Del. Water Gap VII, 11.

H. plumata Loew. DunnfieId VII, 11 (Jn): Boonton VI, 16 (GG).

H. quinquepunctata Say. Boonton VI, 16 (GG); Lucaston IX, 7 (Dlie).

\section{ALLOPHYLA Loew.}

A. Iævis Loew. - Delaware Water Gap VII, 12.

\section{ANOROSTOMA LOEW.}

A. marginata Loew. Clementon V, 30 (Hk); DaCosta VI, 3, Lucaston V 30, Brown's Mills VII, 4 (Dke).

\section{TEPHROCHLAMYS LOEW.}

T. rufiventris Meig. Orange $\mathrm{Mts}$. VII (Wdt).

\section{LERIA Desv.}

L. pectinata Loew. Merchantrille VII, 15 (Dke); Sea Isle City VII, 22.

L. pubescens Loen: Forest Hill IV (Wdt); Clementon V.

L. tristis Loew. Newark VI.

L. defessa O. S. Forest Hill IV (Wdt).

L. helvola Loew. (Scoliocentra) Dunnfield VII, 14, Newark VI, 13 (Jn); Boonton VI, 16 (GG). 
Family BORBORID王.

Medium to small black, brown or yellowish flies, having a short. quick flight. They are almost invariably found about decomposing organc, matter, and often hover in clouds about dung or sewage, where their larvæ live.

\section{LIMOSINA Macq.}

L. limosa Meig. Culver's Lake V, 29, New Brunswick VII, Ocean Co. V (Coll).

\section{BORBORUS Meigen.}

B. equinus Fall. Culver's Lake V, 29 (Coll); Newark VI, 16, Westville V, 19 (Jn); Riverton iV, 8 (Dke).

B. geniculatus Meig. Boonton III, 3 (CG); Merchantville XI, 16 (Dke).

\section{SPHAEROCERA Latr.}

S. subsultans Fab. Culver's Lake V, 30, Newark (Coll); Woodbury V, $14(\mathrm{Jn})$.

\section{Family SCIOMYZID.E.}

Head rounded, short, as broad or broader than the thorax. face retreating, abdomen long and narrow. Legs and wings long, the latter exceeding the abdomen. The flies occur along the banks of streams in which the larvæ live, and the wings are often ornamented. Nonc are harmftil in any way.

\section{SCIOMYZA Fallen.}

S. nana Fallen. Trenton VIII, 21 (HK); Riverton IX, 1, Camden VIII, 21 (Jn); Cape May IX, 21 (DKe).

S. obtusa Fallen. Trenton VIII, 21 (Hk); Westville V, 19.

S. pucera Loew. Trenton VIII, 21 (Hk); Riverton IX, 29.

S. apicata Loew. Trenton V, 24 (Hk).

S. humilis Loew. Trenton VIII, 19 (Hk).

\section{DRYOMYZA Fallen.}

D. simplex Loew. DunufieId VII, 14, Dover VI, 18.

\section{NEUROCTENA Rond.}

N. anilis Fall. Dunnfield, Del. Water Gap VII, 12.

TETANOCERA Latr.

T. arcuata Loew. Chester VIII, 7 (Coll); Dover VI, 18, Merchantville VI, 28. 



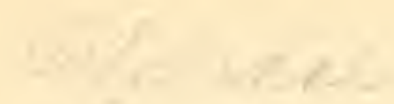

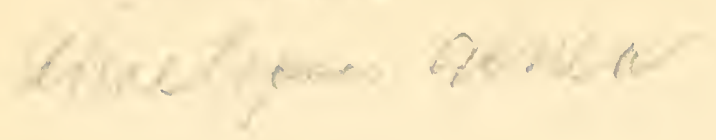


T. flavescens Loew. Del. Water Gap VII, S, 15, Morris Plains VI, 25, Westville VIl, 12 (Jn); Merchantville VI, 26 (Dke).

T. combinata Loew. Elizabeth VII, 24 (Kp); Westville V, 19, Lenola V, 3), Woodbury VI, $T$ (Jnl); Pemberton VII, 18 (Hk); Anglesea V, 28 (Dke).

T. lineata Say. Newark, salt meadow IX (Wit), X, 30 (Sm).

T. sparsa Loew. Dunnfield, Del. Water Gap VII, 15.

T. pallida Loew. Dunnfield VII, 8, Atco VII, 9 (Jn); Chester VIII, 7 (Coll); Camden V.I. 6 (Kp).

T. umbrarum Loew. (bictipes Loew.) Dunnfield VII, 15, Westville V, 19, Lenola V, 30 (Jn); Pemberton VII, S (Hk); Cape Nay IX, 21 (Dke).

T. saratogensis Fitch. Chester IX, 1, Paterson VI, 7 (Coll:; Pembertor VII, 8 (Hk); Atco VII, 9, Mullica Hill V, 30, Anglesea VII, 25.

T. clara Loew. New Hope VII, 10 (HK); Dunnfield VII, S, Merchantville VI, 28, Atco VI, 17, Clementon VIII, 9.

T. plebeja Loew. Boonton VI, 19 (GG); Culver's Lake V, 29 (Sm); Dunnfield VII, 8, Westrille VIII, 28, Woodbury VI, 7.

T. plumosa Loew Jameshurg VIII, 10 (Sm); Trenton IX, 7, Ashland VI, $22(\mathrm{Hl})$; Lenola $\mathrm{V}, 30$, Atlantic City VIII (Jn).

T. canadensis Macq. Ashland YI, 22 (HK).

\section{SEPEDON Latr.}

S. armipes Loew. Westrille V, 19, Lenola V, 30 (Jn); Pemberton YII, 8 ( $\mathrm{Hk}$ ).

S. pusillus Loew. Westrille V. 19, VII, 21 (Jn); Ashland VII, 16, Pemberton IX, 7 ( $\mathrm{Hk})$.

S. fuscipennis Loew. Trenton VII, 5 (Hk); Wrestville IV, 19, V, 19, VIIİ, 23 (Jn); DaCosta VII, 17 (Dlie); Clementon V, 1 (CG).

\section{Fanily SAPROMYZZID E.}

Small species, the head as broad or broader than the thorax, antenna short and porrect, legs never elongate. The ovipositor is not horny but ends tube-like. The larvæ are slender and live in decaying vegetation.

\section{LONCHAEA Fallen.}

L. rufitarsis Macq. Palisades VI (Lv); Iarvæ and pupæ at, Riverton in decayed wood IV. 3, imagoes IV, 16, Atco VII, 7 (Jn); Lahaway VII, $5(\mathrm{Sm})$.

L. polita Say. Clementon X, 10 (CG).

PALLOPTERA Fallen.

P. superba Loew. Forest Hill VII, Orange Mts. VIII (Wdt) 


\section{CAMPTOPROSOPELLA Hendel.}

C. vulgaris Fitch. (Pachycerina verticalis) Chester IX, 2 (Coll); Trenton IX, 7, Clementon $\mathrm{V}, 30$ ( $\mathrm{Hk})$; Jamesburg VII, 4, Merchantville VI, 28, Anglesea VII, 19.

\section{LAUXANIA Latr.}

L. obscura Loew. Culver's Lake V, 29 (Sm); Dover VI, 17, Jamesburg VII, 4, Mullica Hill, Clementon V, 30.

L. gracilipes Loew. Palisades VII, 26 (Lv); Del. Water Gap VII, 11, Lenola VIII, 7, Clementon VIII, 11 (Jn).

L. cylindricornis Fab. Trenton V, 21 (Hk); Ocean Co. V (Sm); Clementon $\mathrm{V}, 30$.

L. latipennis Coq. Buena Vista VI, 7 (Li); Egg Harbor VII, 10 (Sm).

L. opaca Loew. Buena Vista VI, 8 (Li); Avalon VI, 9.

L. muscaria Loew. Merchantville VI, 28, Avalon VI, 8 .

\section{SAPROMYZA Fallen.}

S. decora Loew. Pemberton VIII, S (Hk); South Camden VI, 6 (Li).

S. compedita Loew. Jamesburg VII, 4, Atco VI, 4 (Jn); Anglesea V, 28 (Sm).

S. philadelphica Macq. New Brunswick VII, 20, Jamesburg VII, 15 (Sm); Cramer Hill VI, 10 (CG); Anglesea V, 28 (W).

S. fraterna Loew. Chester VII, 5 (Coll); Merchantville VI, 28.

S. umbrosa Loew. Lahaway VI, 21 (Sm); Atco VI, 17, Merchantville VI, 28, Anglesea VII, 10.

S. macula Loew. New Brunswick VII, 1 (Sm); Atco VII, 7, Westville V, 19, Cape May VIII, 20.

S. bispina Loew. Trenton VI, 3, Jamesburg VII, Anglesea VII (Coll).

S. quadrilineata Loew. Trenton V, 20, Glassboro V, 19 (Hk); Jamesburg VII, 4, Merchantville VI, 28, Clementon V, 30.

S. Iupulina Fab. Boonton VI, 6, (GG); Middlesex County VII, 7 (Sm); Trenton Y, 21, Lucaston IX, 9, Ashland T, 13 (HK); Jamesburg VII, 4, Clementon $\mathrm{V}, 30$ ( Jn).

S. longipennis Meig. Clementon V, 10.

S. innuba Giglio-Tos. Riverton VI, 20.

S. houghii Coq. Atco VII, 12, Egg Harbor VII, 10 (Coll).

S. connexa Say. Merchantville T, 26, National Park VI, 10 (Dlie).

S. magna Coq. Anglesea V, 28 (Dke).

S. rotundicornis Loew. Malaga VI, 1 (Dlie).

\section{Family ORTALID.玉.}

Small or medium-sized flies, often with metallic colors, the wings banded with brown or black. Head of good size, front broad, legs stout and only moderately long. The larval stages are not well known. 




\section{PYRGOTA Wied.}

P. undata Wied. Caldwell (Cr); Orange MIts., Woodbury V, 22 (CG); Atco VI, 19 (Nell); Clementon VI, 5 (Dlie).

P. valida Harris. Caldwell V, 16 (Cr); Westville V, 18, VII, 12 (div).

\section{AMPHICNEPHES Loew.}

A. pulla Wied. (pertusus Lw.) Newark VI, 16, Jamesburg VII, 4, Atco VI, 4, Buena Vista VI, 11, DaCosta VIl, 30 (Jn); Wenonah Vi, 14 (Dke); Egg Harboi VII, 10 (Coll).

\section{RIVELLIA Desv.}

R. conjuncta Loew. Jamesburg VII, 4, Atco VII, 12 (Jn); Buena Vista VI, 14 (Li); Malagal VII, 20, Anglesea V, 28 (W).

R. viridulans Desv. Throughout the State V-VIII, common.

R. quadrifasciata Macq. New Brunswick VII, 30 (Sm); Jamesburg VII, 15, Westville VI, 26, Clementon $\mathrm{V}, 30$, VIII, S (Jn); Anglesea $\mathrm{V}, 28$ (II).

R. flavimana Loew. Westrille $\mathrm{V}, 19$ (Jn); Clementon $\mathrm{V}, 30$ (Hk).

R. variabilis Loew. Avalon TII, 29 (Jn); Anglesea V, 28, VII, 19 (div).

R. pallida Loew. Boonton VII, 10 (GG); Newark VI, 13 (Jn); Ocean Co. i (Sm); Anglesea VI, 11 ( Hk).

R. brevifasciata Johns. Atco VI, 18 (Jn); Lacy VII, 14 (Dke).

R. boscii Desv. Trenton $\mathrm{V}, 21(\mathrm{Hk})$.

\section{TRITOXA Loew.}

T. flexa Wied. Westville VIII, 23, Woodbury VI, ¡. Atco VI, 18 (Jn); Malaga IX, 15 (CG); Lucaston IX, 9 (Hk).

T. incurva Loew. Caldwell (Cr).

CAMPTONEURA MaCq.

C. picta Fab. Throughout the State VI-X, common.

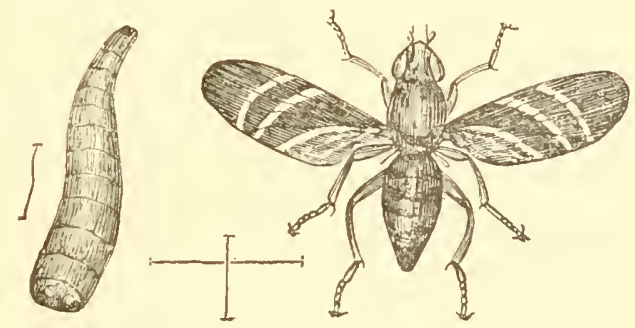

Fig. 332--The onion Ay. Triwra Acra and 1 ts larva: enlarged.

IDANA Loew.

I. marginata Say. "New Jersey" (A E S).

TEPHRONOTA LOEW.

T. narytia Walk. (humilis Loew.) Jamesburg VII, 4, Atco VII, 9. Buena Vista VI, 11 (Jn); Belleplain IX, 8, Brown's Mills VII, 5 (Dke). 
SOO REPORT OF NEIV JERSEY STATE MUSELM.

TETANOPS Loew.

T. Iuridipennis Loew. Camden VII, 2424 (DaCosta VII, 30, Clementon VII, 8, VIII, 9 (Jn); Glassboro VII, 5 (CG).

\section{CALLOPISTROMYIA Hendel. (CALLOPISTRIA Loew.)}

C. annulipes Macq. Boonton VII, 18 (GG); Merchantville VIII, 1 (Dke).

\section{PSEUDOTEPHRITIS JohnS. (STICTOCEPHALA LOeW.)}

P. vau Say. Boonton VIII, 12 (GG); Westville VII, 21 (Jn); National Park V, 20 (Dke); Prospertown IX, 25 (Sm).

P. corticalis Loew. New Brunswick V, 18 (Sm); Riverton IV, 22.

\section{CHRYSOMYZA Fallen.}

C. demandata Fab. Bloomfield IX (Wdt); New Brunswick X, 18 (Sm); Riverton IX, 9, X, 20 (Jn).

\section{EUXESTA Loew.}

E. notata Wied. Riverton V, 29, VIlI, 21, Westville VI, 27 (Jn); Glassboro V, 19 (CG); Cumberland Co., bred from onions ( $\mathrm{Sm}$ ).

E. scoriacea Loew. Lacy V, 27 (Dlie); Sea Isle City VII, 22, Two-Mile Beach VII, $22(\mathrm{Jn})$.

\section{CHAETOPSIS LoeW.}

C. ænea Wied. New Brunswick (Sm); Trenton V, 21 (Hk); Pemberton V, 10 (CG) ; Lenola V, 30, Anglesea VII, 16, Cape May VI, 14.

C. apicalis Johns. Avalon VI, 9, Sea Isle VIl, 22, Anglesea VII, 16.

\section{SEOPTERA LOEW.}

S. vibrans Linn. Caldwell (Cr); New Brunswick VI, 4, Egg Harbor VII, 10 (Coll); Newbold VI, 30 (Dke).

¿. colon Loew. New Jersey.

\section{STENOMYIA Loew.}

S. tenuis Loew. Atco VI, 4, 18, Buena Vista VI, 11, DaCosta VII, 30, Clementon VIII, 6.

\section{EUMETOPIA Macq.}

E. rufipes Macq. Trenton VII, 7, Pemberton VII, S (Hk); Camden VIII, 24, IVestville VII, 4, 21.

\section{SEPSISOMA Johns.}

S. flavescens Johns. Trenton VII, 3 (Hk); Westville VIII, 19 (Jn); Wenonah VI, 14 (Dke). 




\section{Family 'TRIPFTIDA:}

The "peacock files," so called because of their habit of elevating the wings and strutting about, peacock like. These wings are often prettily marked and spotted with black or brown. In the female the abdomen is often prolonged into a horny ovipositor. The flies are gracefully built, fly slowly and are noticeable by keeping their wings in constant motion. Nost of the members of the series feed in plant tissue of some kind, either in leaves, in stems or in fruits, and a number of them are gallmakers. The only species of economic importance in this State is the "Apple maggot," which injures some of the early summer varieties. The only remedial measure is the prompt removal and disposal of all fruit from trees known to be infested.

\section{STRAUSSIA Desv.}

S. longipennis Wied. Boonton VII, 24 (GG); Caldwell (Cr); Ft. Lee (Bt), Orange MIts., Elizabeth V, 21, Canden V, 26 (Kp).

ACIDIA Desv.

A. fratria Lcew. Trenton $V, 31$ (Hk); Riverton $V, 20$ (CG).

\section{SPILOGRAPHA Loew.}

Z. flavonotata Macq. Glassboro VII 6 (CG).

TRYPETA Loew.

T. palposa Loew. Aralon V1, 8, on thistle (Jn); Anglesea V, 28 (W).

\section{PLAGIOTOMA LOEW.}

P. obliqua Say, New Jersey (Bt); Clementon VilI, $6(\mathrm{Jn})$.

\section{CEDASPIS Loew.}

O. atra Loew. Lucaston IXं, 9, Ashland VI, 23 (Hk); Riverton VI, 18, Avalon VI, 8, Cape May VI, 14 (Jn); Belleplain IX, 16 . Dlie); Anglesea $\mathrm{V}$, VI (div).

o. polita Loew. Generally distributed; forms a gall on Solidago (Bt).

\section{RHAGOLETIS Loew.}

R. cingulata Loew. Atl. Highlands VII, 11 (Lv); Long Branch VII (OS).

R. tabellaria Fitch. Caldwell (Cr); Jamesburg VII, 4 (Jn); Buena Vista VII, $10(\mathrm{~L} / \dot{\mathrm{i}})$. 


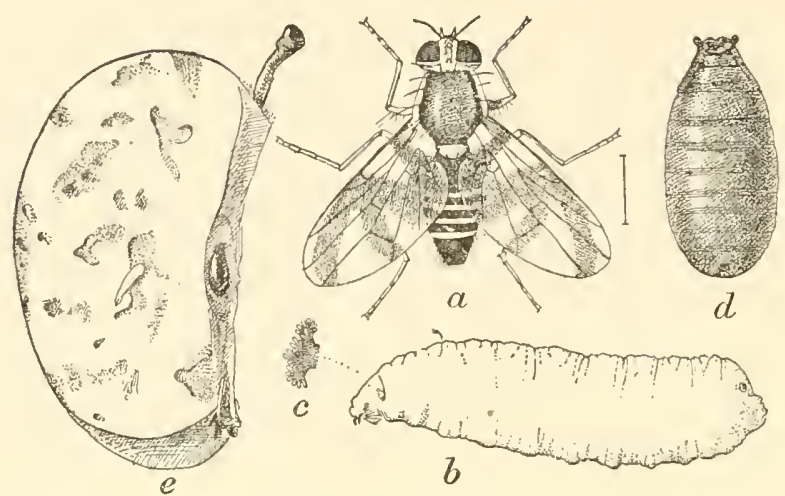

Fig. 333--Apple maggot, Rhagoletis pomonella: $a$, adult; $b$. larva; $c$, spiracle of larva; $d$, puparium; $e$, apple, showing irjury by larva: all enlarged.

R. pomonella Walsh. Montclair; the apple maggot, locally injurious but seems confined to a very few varieties (Sm); Weymouth VIII, 8, DaCosta VIII, 16, hred from huckleberries (Dke).

\section{EUTRETA Loew.}

E. sparsa Loew. Caldwell (Cr); Jamesburg VII (Dke); Trenton VI, 27, VIII, $26(\mathrm{Hk})$.

\section{EUROSTA Loew.}

E. comma Wied. Chester (Dn); Trenton IX, 7, Clementon IX, 5 (Hk); Glassboro IX, 19 (CG).

E. solidaginis Fitch. Ft. Lee (Bt); Trenton V, 21 (Hk); Clementon V, 10 .

E. conspurcata Doane. "New Jersey" (Doane).

NEASPILOTA O. S.

N. alba Loew. Lenola VIII, 7, Clementon VIII, 6; on ironweed.

N. albidipennis Loew. Ashland VII, 16 (Hk); Lenola VIII, 7, Westville VIII, 14, Clementon VIII, 6; on ironweed.

N. vernonia Loew. Westville VIII, 16, Clementon VIII, 6, Lenola VIII, 7 ; on ironweed.

N. achilleæ Johns. Avalon VI, 30; on yarrow "Achillea millefolium."

\section{ICTERICA LOEW.}

I. circinata Loew. Trenton VIII, 21 (HK); Westville VIII, 23, IX, 13.

I. seriata Loew. Forest Hill VIII (IVdt); Trenton VII, Clementon VIII, $23(\mathrm{Hk})$.

\section{TEPHRITIS Latr.}

T. geminata Loew. Jamesburg VII, 4, Atco VII, 12 (Jn); Riverton VII. 3, Egg Harbor VII, 10 (Coll); Pemberton VII, 11 (CG). 


T. picturata Snow. Avalon VII, 8 ( $\mathrm{Hk})$.

T. albiceps Loew. Caldwell ( $\mathrm{Cr})$; "New Jersey" (Bt).

T. clathrata Loew. Riverton VII, 19.

T. platyptera Loew. Merchantville V, 26 (Dke); Clementon V, 30 (Hk).

T. fucata Fab. Wildwood Vill, 12, Cape May Vill, 1 (Vk).

\section{EUARESTA Loew.}

E. bella Fitch. Caldwell (Cr); New Brunswick VIl, 20 (Sin); Jamesburg VII, 4, Atco Vil, 9, Clementon VI, 8 (Jn).

E. festiva Loew. Trenton IX, 7 (Hk); Westville VIII, 13, 2 S.

E. æqualis Loew. Trenton $\mathrm{X}$. 7 (Hk); Lucaston $\mathrm{X}, 15$ (Dke); Westville VIII, 28 on "Ambrosia artemisiæfolia," Anglesea IX, 1.

E. subpura Johns. Wildwood VIII (Jn); Anglesea VIII (Sn: .

\section{URELLIA Desv.}

U. abstersa Loew. Riverton VIl, 18 (dix); Avalon VII, 22 (Jn); Anglesea IX, 5 (Dke).

U. mevarna Walk. (solaris Loew.) Penbryn Vlll, 2 (Dke); Egg Harbor VII, 10 (Coll); Cape Mlay VI, 22.

\section{Family MICROPEZID无.}

Flies slender or very slender, with large wings and long legs, antennæ variable, face retreating in profile. The larval habits are not definitely known.

\section{CALOBATA Meigen.}

C. antennipes Say. Dunnfield VII, \&, Princeton VII, 21, Jariesburg VII, 4 (Jn); Collingswood VII, 17 (CG).

C. lasciva Fab. Orange Mts. VII (Wdt); Atlantic City VII (Jn); Anglesea (W).

C. univitta Walk. Princeton VII, 21 (Jn); Cramer Hill V, 30 (CG).

c. alesia Walk. New Jersey V (A E S).

\section{Family SEPSID王.}

"The flies belonging to this family are usually small. black and elongated, with the abdomen narrowed at the base, thickened and curved downward toward the extremity; with transparent, iridescent wing, usually hyaline, but often with a spot or spots toward the end, and are usually observed about decaying vegetables, excrement, cheese, ham, etc., often in swarms. The flies, for the greater part, run about actively, and are quick in flight. The best known are the species of 'Piophila,' the larvæ of which are known as 'cheese-mites.' These larvæ live in 


\section{O4 REPOR'T OF NEW JERSEY STATE MUSEUM.}

cheese, in ham or bacon, or, in general, in any fatty material, and often do much damage, being especially troublesome in pork-packing establishments. From the peculiar power of leaping possessed by the maggots they are often called 'skijpers'; the act is performed by the larva seiz ing with its extended mouth hooklets the edge of the posterior truncature of the body and then suddenly releasing it while pulling hard."-Williston.

PROCHYLIZA Walk.

P. xanthostoma Walk. Riverton IV, 9, X, 9 (Jn); Cape May IX, 21 (Dlie).

\section{SEPSIS Fallen.}

S. violacea Meig. New Brunswick VII, 20, Jamesburg VII, 15, Ocean Co. $\mathrm{V}(\mathrm{Sm})$; Trenton VII, 6 (Hk).

\section{NEMOPODA Desv.}

N. cylindrica Fab. Dover VI, 17, Morris Plains VI, 25, Riverton IX, 17, Trenton $\mathrm{V}$, 20 ( HK).

N. minuta Wied. Chester IX, 2 (Coll); Newark VI, 14, Riverton VII, 3.

\section{PIOPHILA Fallen.}

P. case i Iinn. This is the cheese mite or stipper, and occurs everywhere.

P. nigriceps Meig. Pemberton $\mathrm{V}, 10$ (CG).

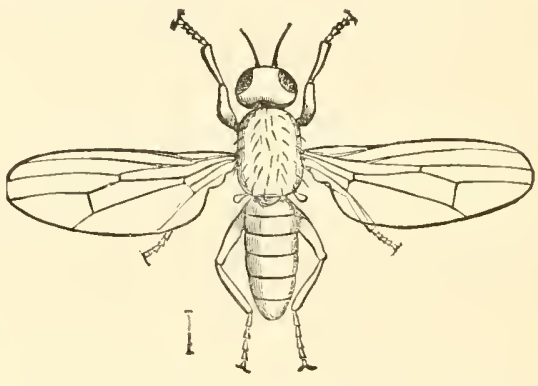

Piophita casei, parent of "skippers" in cheese, etc.

Fig. 334 .

\section{Family PSILIDE.}

Slender flies of moderate size, with large wings, long legs and at least moderately long antennæe. The larvæ, so far as known, live in roots or galls.

\section{LOXOCERA Meigen.}

L. cylindrica Say. Del. Water Gap VII, 12, Camden VI, 10, Woodbury VI, 7, Clementon V. 30, Mullica Hill (Jn); Trenton VII, 11 (Hk).

L. pectoralis Loew. Dumnfield, Del. Water Gap VII, 11.

L. pleuritica Loew. Dunnfield, Del. Water Gap VII, 12. 


CHYLIZA Fallen.

C. notata Loew. Caldwell ( $\left.\mathrm{Cr}^{\circ}\right)$.

C. apicalis Loew. Riverton VII, 2 (Jn); MIerchantville VI. 4 (Dlie).

\section{PSILA Meigen.}

P. bivittata Loew. Clementon, Lenola V, 30.

P. collaris Loew. Newark VI, 13, Atco VI, \& $\left(\mathrm{Jn}_{\mathrm{n}}\right)$; Clementon VI, 7 (Li); Brown's Mills VI, 9 (Dlie).

P. Iateralis Loew. Trenton V, 20 (Hk); Riverton VI, 20.

\section{Family DIOPSIDE.}

Our only species belonging to this family is easily recognized by the two lateral horns or processes from the side of the head upon which the eyes are situated. It occurs on skunk cabbage.

\section{SPHYRACEPHALA Say.}

S. brevicornis Say. Newark V (Wdt); Riverton IV, 14 (Jn); Clementon $\mathrm{V}, 5$ (Hk); Wenonah $\mathrm{V}, 30$ (Dlie).

\section{Family EPHYDRID.玉.}

"The flies of this family are never large, often small or even minute. The greater number of the species are inhabitants of wet places, about marshy ground, meadows, etc. They are always thiuly nilose or bare species, and never with bright colors. The exceedingly large head and mouth of some species are very characteristic, but in others this character is not so apparent, and there is sometimes difficulty in separating the genera from those of the 'Drosophilida.' The larvæ of many forms are very peculiar, resembling the rat-tailed larvæ of the 'Syrphidæ' in many cases."-Williston.

In New Jersey the species are not notably abundant; but they occur in countless millions in the great salt lake in Utah, and in nther alkaline lakes and ponds of the northwestern desert region.

\section{DICHAETA Meigen.}

D. brevicauda Loew. Clementon V, 5 (CG); Ocean County $V$ (Sm).

D. caudata Fall. Rivertor IV, \& (Dke); Nanahawkin IX, 5 (Hk).

\section{NOTIPHILA Fallen.}

N. carinata Loew. Cape May Vr, 22.

N. scalaris Loew. Shark River VII, 12 (Jn); Clementon V. 30 (Hk); Bridgeport V, 20 (Dlie).

N. vittata Loew. Woodbury VI, 7.

N. bella Loew. Westville VI, 15. 
SO6 REPORT OF NEIT JERSEY STATE MUSEUM.

\section{PARALIMNA LOEW.}

P. appendiculata Loew. Riverton IX, 11, Westville V, 19, Cumberland Co. IX, 1 (Jn); Ashland V, 13 ( $\mathrm{Hk})$.

P. decipiens Loew. Trenton VIII, 19 (Hk).

\section{PSILOPA Fallen.}

P. atrimana Loew, Riverton X, 9 .

P. scoriacea Loew. Delaware Water Gap VII, 13 (Jn); Trenton VIII, 23 (HK).

P. aciculata Loew. Avalon VIII, $8(\mathrm{Hk})$.

P. fulvipennis Hine. Cape May VII, 1 (Vk).

P. flavida Coq. Avon IX, 27 (Hk).

\section{GASTROPS Will.}

G. nebulosus Coq. Trenton VIII, 21 (Hk); Clementon V, 5 (CG).

\section{ILYTHEA Haliday.}

I. spilota Curtis. Riverton IX, 17.

\section{DISCOCERINA Macq.}

D. lacteipennis Loew. Cape May VI, 14.

D. magna Coq. Riverton VIII, 17.

D. parva Loew. Ashland V, 13 (Hk).

D. simplex Loew. Trenton VIII, 23, Manahawkin IX, 5 ( $\mathrm{Hk}$ ).

\section{HYDRELLIA Desv.}

H. scapularis Loew. Trenton VII, 21 (Hli); Riverton IX, 1' (Jn); Manahawkin IX, 5.

H. valida Loew. Cape May VI, 4 (Vk).

H. hypoleuca Loew. Trenton VIII, 21 (HK); Avon IX, 27.

H. cruralis Coq. Riverton IX, 19 (Hk).

\section{PELINA Haliday.}

P. brevis Walk. Ashland VI, 22 (Hk).

HYADINA Halid.

H. rufipes Meig. Trenton VIII, 23 (Hlk).

OCHTHERA Latr.

o. mantis DeGeer. Camden VII, 1 (Kp); Clementon V, 30 (Jn); Anglesea VIII, 5 (Hk); Cape May IX, 21 (Dike). 




\section{BRACHYDEUTERA LOEW.}

B. argentata Walk. Riverton VIII, 3 (Jn); Cape May VIII, 20 (Vk).

\section{PARYDRA Stenhammer.}

P. bituberculata Loew. Dunnfield VII, 15 (Jn); Riverton IV, 26 (CG).

P. pinguis Walk. Shark River VII, 12.

P. quadrituberculata Loew. Manahawkin IX, 5 ( $\mathrm{Hk}$ ); Cape May VI, 4 (Vk).

P. imitans Loew. Near Anglesea Junction TI, 25 (Vk).

P. breviceps Loew. Manahawlin IX, 5 ( $\mathrm{Hk}$ ).

\section{EPHYDRA Fallen.}

E. subopaca Loew. Long Branch VI, 12, Ocean City V, 7, Wildwood VII, 12 (Jn); Cape May (Dke).

E. nana Walk. Cramer Hill VIII, 24, Riverton X. 9.

\section{SCATELLA Desv.}

S. stagnalis Meig. Newark XII, 7 (Wdt); Trenton VIII, 23 (Hk); Iona IX, 12 (CG); Avalon VII, 22.

S. flavillacea Loew. Cape May VI, 14.

S. oscitans Walk. Clementon $V, 1 t$ (CG).

S. callosicosta Cress. Seaside Park $\mathrm{V}, 16$ (V'k).

S. lugens Loew. Riverton $\mathrm{X}, 9$.

\section{CAENIA Desv.}

S. spinosa Loew. Trenton VIII, 21 (Hk); Ocean Co. V (Sm); Anglesea VII, 19, Cape May VI, 22.

c. fumosa Sten. Caye May IX, 17, at light (T'k).

\section{CANACE Haliday.}

C. snodgrassii Coq. Atlantic City $\mathrm{Y}, 6$.

LIPOCHFTA COq.

L. slossonæ Coq. Anglesea V1I, 19, Cape May Vi, 6.

\section{Family OSCINIDE.}

The "frit flies." They are small, bare species, with hemispherical head, flat front, short antennæ, short wings and ovate or elliptical abdomen. The legs are short and moderately stout. They are often colored or banded, and are common in grass and meadow lands. The larvæ live in the stems of grasses of all kinds, and may become locally injurious. 


\section{MEROMYZA Meigen.}

M. americana Fitch. Infests wheat and other grasses; com mon throughout the State V-VIII, but thus far not injurious.

\section{CHLOROPS Meigen.}

C. versicolor Loew. New Brunswick, Anglesea $\mathrm{V}, 28$ (Sm); Jamesburg VII, 4, Atco VII, 9 (Jn); Clementon VVIII (div).

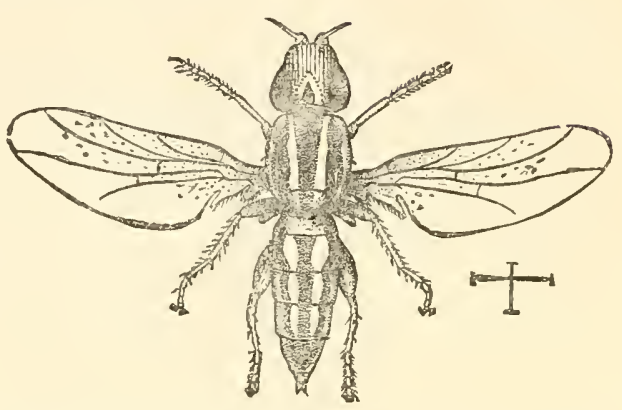

Fig. 335.-Meromyza americana, the stem maggot fiy.

C. nigripes Coq. Trenton VIII, 21, Manahawkin IX, 5 (Hk).

C. crocota Loew. Newark V (Wdt); Clementon VIII, 6.

C. rufescens Coq. Trenton VIII, 21, Riverton VII, 18 (Hk).

C. sulphurea Loew. Trenton V, 20, Ashland VII, 15, Clementon V, 30 (Hk); Atco VI, 4, VII, 9.

C. confluens Loew. Trenton VIII, $19(\mathrm{Hk})$.

C. grata Loew. Del. Water Gap VII, 12, Princeton VII, 21.

C. assimilis Macq. Newark, Ocean Co. V (Sm); Trenton V, 20, Ashland V, 13 (Hk); Riverton X, 9, Princeton VII, 21, Clementon V. 9, Anglesea VII.

C. subnigra Coq. Manahawkin IX, 5 ( $\mathrm{Hlk})$.

C. procera Loew. Del. Water Gap VII, 11, Asbury Park VIII, 16, Clementon VIII, 8.

C. eucera Loew. Jamesburg VII, 4.

c. unicolor Loew. Trenton V, 20 ( $\mathrm{HK}$ ); Princeton VII, 21, Riverton V, 14, Westville VII, 12, DaCosta VII, 30.

C. variceps Loew. Ocean Co. V (Sm).

C. obscuricornis Loew. Atco VI, 4, 18.

C. melanccera Loew. Riverton V, $14(\mathrm{Jn})$; Ashland V, 13, Clementon V, $30(\mathrm{Hlk})$.

C. proxima Say. Trenton V, 20, Iona V, 16 (Hk); Lucaston V, 28, Brown's Mills V, 21. (Dke).

C. pulverea Coq. Merchantville V, 26 (Dke).

\section{HIPPELATES Loew.}

H. plebejus Loew. DaCosta VI, 4 (Dke); Clementon V, 12, VIII, S, Avalon VI, $9(\mathrm{Jn})$; Anglesea V, $28(\mathrm{Sm})$.

H. nobilis Loew. Shark River VII, 12, Avalon VI, 9, 30.

H. flavipes Loew. Shark River VII, 12, Riverton IX, 11 (Jn); Laurel Springs VI, 13, Brown's Mills VII, 1 (Dke). 


H. pusio Loew. Riverton $\mathrm{V}, 14, \mathrm{X}, 9$ (Jn); Trenton VIII, 23, Ashland $\mathrm{V}$, 13 ( $\mathrm{Hk}$ ).

H. plumbellus Wied. Riverton $\mathrm{V}, 14$.

H. bicolor Coq. New Biunswick VII (Sm).

H. stramineus Loew. Riverton IX, 11 (Jn); Lakehurst VII. 7 (Coll).

H. microcentrus Coq. Mt. Holly III, 17, Brown's Mills VI, 9 (Dlie); Ashland $\mathrm{VI}, 22$ (Hk); Anglesea $\mathrm{V}$, $2 S$ (div).

\section{ELACHIPTERA Macq.}

E. eunota Loew. Trenton VII, 5 (Hk); Avalon VI, 30.

E. nigriceps Loew. Sliark River VII, 12, Riverton VII, 3, Clementon V, 30; bred from Lotus infested by "Pyrausta nelumbialis" VII, 13.

E. costata Loew. New Brunswick VII, 20, Ocean Co. V (Sm); Princeton VII, 21 (Jn); Merchantville XI, 16 (Dlie).

E. formosa Loew. Riverton IX, 8 .

E. longula Loew. Clementon VI, 3.

\section{MOSILLUS Latr.}

M. æneus Fall. Avon IX, 27 (Hk).

\section{SIPHONELLA Macq.}

S. cinerea Loew. Riverton X, 9, Cramer Hill VIII, 24 (Jn); Ashland VII, 15 (Hli); Brown's Mills IX, 16 (Dlie).

S. pumilionis Bjerk. Riverton VII, 3.

S. inquilina Coq. Manumuskin X, S (Dke); Clementon X. \&. Iona IX, 12 (CG); Manahawkin IX, 15 (HK).

\section{OSCINIS Latr.}

O. carbonaria Loew. Ocean Co. V (Sm); Avon $1 X, 27$ (Hk).

O. trigramma Loew. Shark River VII, 12 (Jn); Lucaston IX, 15 (Dke); Anglesea V, 2S ( $\mathrm{Sm})$.

O. coxendix Fitch. Riverton X, 9 (Jn); Lucaston IV, 4 (Dke); Avon IX, 27 ( $\mathrm{Hlk})$.

o. soror Macq. Riverton IV, \& (Dke); Ocean Co. V (Sm).

\section{Family DROSOPHIL,IDE.}

The species in this family are small, plump, without pile, the bristles of the head and legs conspicious. Abdomen usually short and broad, genitalia not prominent, colors tending to yellow. They are often abundant about decomposing or fermenting fruit, about cider-mills, wine-presses, etc., whence they are called "pomace flies." The larvæ live in this pomace and on the surface of the scum of the fermenting fruit juice. 
SIO REPORT OF NEIV JERSEY STATE MUSEUM.

\section{PHORTICA Schiner.}

P. vittata Coq. Del. Water Gap VII, 12, Avalon VI, 8 (Jn); Anglesea V, 28 (Dke).

P. leucostoma Loew. Dunnfield VII, 8, 12, Dover VII, 16 (Jn); Delair VIII, 18 (Dke).

P. humeralis Loew. Riverton VII, 30, Westville VII, 26.

\section{STEGANA Meig.}

S. coleoptrata Scop. Delaware Water Gai VII, 13.

\section{CURTONOTUM Macq.}

C. helvum Loew. New Brunswick VII, 7 (Sm); Princeton VII, 21, Westville VII, 26, VIII, 23, Atco VII, 9 (Jn); Riverton IX, 20 (CG); Stone Harbor VIII, 3 (Dke).

\section{DROSOPHILA Fallen.}

D. amœna Loew. Westville VII, 21, Glassboro VIII, 28 (GG); Merchantville XI. 16 (Dke).
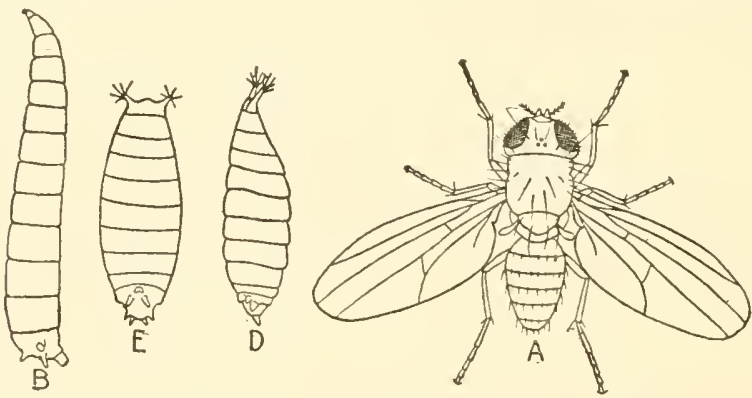

Pommace fly; Drosophila ampelophila: $a$, adult; $b$, larva;

d. $e$, pupa.

Fig. 336 .

D. ampelophila I.oew. Common "fruit" or "vinegar fly"; everywhere in the State after midsummer.

D. funebris Fab. Riverton VI, 1.

D. quadrimaculata Waik. Del. Water Gap VII, 12, Merchantville VI, 28 (Jn); New Brunswick VII, 20 (Sm).

D. graminum Fall. Trenton V, 24, Clementon VII, 4 (Hk); Anglesea V, $28(\mathrm{~W})$.

D. adusta Loew. New Brunswick VII, 20 (Sm).

D. confusa Stæger. Delaware Water Gap VII, 13.

D. colorata Walk. Dunnfield, Del. Water Gap VII, 15.

D. punctulata Loew. Glassboro X, 17 (CG).

D. maculosa Coq. Riverton IX, 23. 


D. inversa Walk. Avalon VI, 8.

D. ordinaria Coq. Riverton VIII, 4.

D. multipuncta Loew. Cape May IX, 23 (Vk).

D. varia Walk. Riverton VI, 15, Newbold VII, 4 (Dke); Lucaston IX, 9 $(\mathrm{Hk})$.

D. tripunctata Loew. Newbold VII, 4, Merchantville XI, 16 (Dke).

D. quinaria Loew. Merchantville XI, 16 (Dke).

D. phalerata Meig. Trenton VIII, 21 (Hk).

D. valida Wilk. Manaliawlin VII, 5 (Hk).

\section{Family GEOMTZID立.}

Small or even minute flies with comparatively large wings. The an tenne are short, arista variable, front broad and bristly below the apex. The larve, so far as known, live in the stems of plants.

\section{DIASTATA Meig.}

D. pulchra Loew. "New Jersey" (A E S).

D. nebulosa Fall. Clezaenton $\mathrm{V}, 16$.

\section{ISCHNOMYIA Loew.}

I. albicosta Walk. (vittula Loew.) Dunnfield V'lI, 12. Princeton VII, 21, Westville VII, 2.

\section{ANTHOMYZA Fallen.}

A. variegata Loew. Del. Water Gap VII, 12 (Jn); New Brunswick VI, 1, Ocean Co. V $(\mathrm{Sm})$.

A. terminalis Loew. Trenton $\mathrm{V}, 24(\mathrm{Hk})$.

\section{SCYPHELLA Desv.}

S. flava Linn. New Brunswick (Sm).

$$
\text { Family IGROMIZIDA. }
$$

Consists of small or minute flies difficult to separate from the allied groups. The front is broad, the antenna short, arista absent, or, when present, bare or only pubescent. The wings are broad, venation resembling that of the allied families. The larvæ vary greatly in habits; some are leaf miners, some feed upon plant lice, others ocrur in galls in which their function is not yet well understood.

$$
\text { NAPOMYZA Haliday. }
$$

N. chrysanthemi Kowarz. Newbold VII, 4 (Dke). Larva is a leaf-miner in Chrysanthemum. 
SI 2 REPORT OF NET JERSEY STATE MUSELM.

\section{CERATOMYZA Schiner.}

C. dorsalis Loew. Riverton $\mathrm{V}, 14, \mathrm{VII}, 3, \mathrm{X}, 10$.

AGROMYZA Fällen.

A. coronata Loew. Ashland V, 13 (Hk); Avalon VII, 22 (Jn).

A. melampyga Loew. Jamesburg VII, 4.
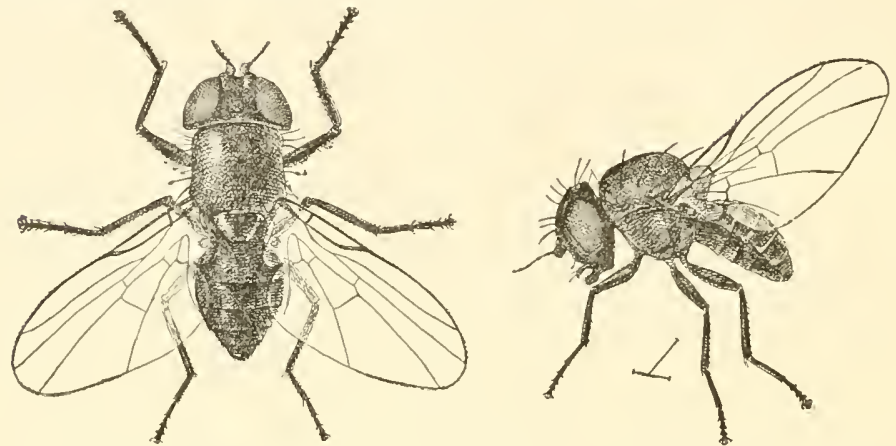

Fig. 337.-Agromyza simplex, from above at left and from side at right.

A. simplex Lnew. Chester IX, 5 (Coll); Newark VI, 13, Riverton VII, 24, Atco VI, 4 ( Jn); Ashland V, 13 ( $\mathrm{Hl})$; larva mines in asparagus.

A. angulata Loew. Del. Water Gap VII, 8, Newark VI, 13.

A. æneiventris Fall. Trenton VIII, 11, Pemberton VII, \& (Hk); Westville VII, 21; larva burrows in roots of clover.

A. dimidiata Walk. Ocean Co. V (Sm); a leaf-miner of cabbage.

A. magnicornis Loew. Riverton VII, 17; a leaf-miner of Iris.

A. parvicornis Loew. Trenton V, 20 (Hk); Riverton VI, 20.

A. jucunda V. d. W. Riverton IX, 17; larva mines in verbena, aster, etc.

A. viridula Coq. National Park V, 6 (Dkie).

PHYLLOMYZA Fall.

P. securicornis Fall. Trenton VIII, 21 (Hk).

\section{DESMOMETOPA LOeW.}

D. m-nigrum Zett. New Brunswick VIII, 26 (Sm).

D. halteralis Coq. Clementon V, 12, Anglesea VII, 19.

D. latipes Meig. Chester IX, 3 (Sm); Clementon X, 18 (Hk).

\section{RHICNOESSA LOeW.}

R. albula Loew. Wildwood VIII, 27, Avalon VII, 19 (Hk); Stone Harbor VIII, 3-12 (Dlie).

EUSIPHONA Coquillett.

E. mira Coq. Del. Water Gal) VII, 10, Bamber IX, 1 (Dke). 


RHYNCHOMILICHIA Hendel. (LOBIOPTERA Wahlb.)

R. indecora Loew. Atco VI, 6, Woodbury VI, 7, Buena Vista VI, 11, Avalon VI, 9.

MILICHIELLA G-TOS.

M. lacteipennis Loew. Brown's Mills VI, 22 (Dlie); Avalon VI, 9.

M. bisignata Coq. Riverton VII, 4.

M. arcuata Loew. Riverton VIII, 25, Anglesea IX, 2 (Jn); Lucaston VIII 10 (Dke).

\section{TRAGINOPS Coq.}

T. irrorata Coq. "New. Jersey."

\section{LEUCOPIS Meig.}

L. simplex Loew. Riverton VI, 19, Clementon VIII, 6, Avalon VI, 9, VII, 22.

L. nigricornis Egger. Del. Water Gal, bred VII. 20, from willow galls collected VII, 11 ( In).

\section{OCHTHIPHILA Fallen.}

O. polystigma Meig. Newark V (Sm); Trenton V, 20, Ashland VIl, 15 (Hk); Westrille VII, 21 (Jn); Egg Harbor VII, 10 (Coll).

o. elegans Panzer. Clementon $\mathrm{V}, 30$.

\section{Sub-order PUPIPARA.}

The term really explains its own meaning, though perhaps the name "louse-flies" may appeal more strongly to the imagination.

The insects are flattened, adapted to live among wool or feathers, and infest chiefly hirds of prey. Among animals the sheep only is infested by a "tick," which is really a degraded, wingless member of this family, They are termed pupipara because the larva remains in the body of the mother until it is mature and ready to enter the pupal stage.

\section{Fanily HIPPOBOSCIDE.}

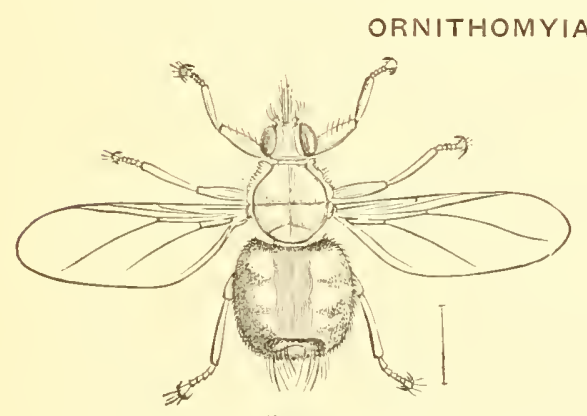

Fig. 338 .

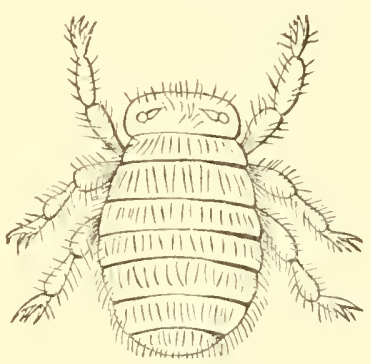

Fig. 339.

Fig. 338.- 1 bird fly, Olfersia species: enlarged.

Fig. 339.--Bee louse: Braula species: much enlarged. 


\section{SI4 REPOR'T OF NEW JERSEY STATE MUSEUM.}

O. anchineuria Speiser. (pallida Say.) On the reedbird IX, 2, and redwinged blackbird VIIl, 19, shot by Mr. Chas. Liebeck along the Delaware River.

\section{OLFERSIA Wied.}

O. americana Leach. On the red-tailed hawk XI, 9, Haddonfield; it also frequents the great horned owl and screech owl.

O. ardea Macq. On American bittern IX, 15, 21, X, 10, and night heron $\mathrm{X}, 15$, shot by Mr. Chas. Liebeck along the Delaware River; little blue heron, Bristol Island, Delaware River (Fowler).

\section{PSEUDOLFERSIA COq.}

P. maculata Coq. Cape May VIII, from a fish häwk (Sli); Lahaway IV, 1, several specimens from fisli hawk, by J. Turner Brakeley.

\section{MELOPHAGUS Latr.}

M. ovinus Linn. The "sheep louse-fly"; infests sheep. everywhere.

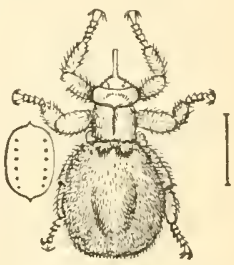

Fig. 340. - "Sheep tick:" Melophagus orinus: enlarged. 




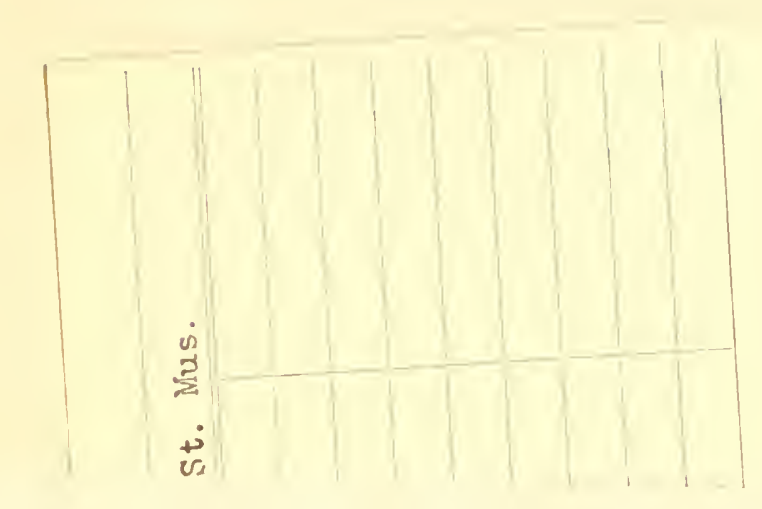




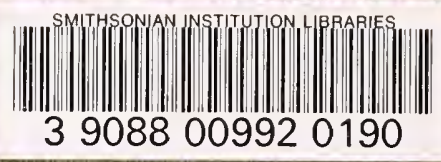

